Mateus Mendes Magela

\section{MATEMÁTICA APLICADA AO ENSINO DE CIÊNCIAS AGRÁRIAS}

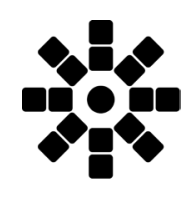

Edifes

VITÓRIA - ES 2018 


\section{of Edifes}

Editora do Instituto Federal de Educação,

Ciência e Tecnologia do Espírito Santo

R. Barão de Mauá, nº 30 - Jucutuquara

29040-689 - Vitória - ES

www.edifes.ifes.edu.br

editora@ifes.edu.br

\section{Reitor}

Jadir Jose Pela

Pró-Reitor de Administração e Orçamento

Lezi José Ferreira

Pró-Reitor de Desenvolvimento Institucional

Luciano de Oliveira Toledo

Pró-Reitora de Ensino

Adriana Pionttkovsky Barcellos

Pró-Reitor de Extensão

Renato Tannure Rotta de Almeida

Pró-Reitor de Pesquisa e Pós-Graduação

André Romero da Silva

Coordenador da Edifes

Giovani Zanetti Neto

\section{Conselho Editorial}

Glória Maria de Farias Viegas Aquije

Felipe Zamborlini Saiter (suplente)

Francisco de Assis Boldt

Pedro Vitor Morbach Dixini ( $1^{\circ}$ Suplente)

Ediu Carlos Lopes Lemos (2º Suplente)

Aldo Rezende

Maria das Graças Ferreira Lobino (suplente)

Karine Silveira

Nelson Martinelli Filho (suplente)

Marize Lyra Silva Passos

Viviane Bessa Lopes Alvarenga

Rossanna dos Santos Santana Rubim (suplente)

Revisão de texto

Thaís Rosário da Silveira

\section{Projeto Gráfico e Diagramação}

Semíramis Aguiar de Oliveira Louzada

Imagem de capa

Marcos Santos/USP Imagens

M191m Magela, Mateus Mendes, 1986-

Matemática aplicada ao ensino de ciências agrárias / Mateus Mendes Magela. - Vitória, ES : Edifes, 2018.

76 p. : il.

ISBN: 9788582633601 (e-book.).

1. Ciências agrárias - Matemática. 2. Matemática aplicada. I. Título.

CDD $22-519$

DOI: $10.36524 / 9788582633601$

@ 2017 Instituto Federal do Espírito Santo

Todos os direitos reservados.

É permitida a reprodução parcial desta obra, desde que citada a fonte.

O conteúdo dos textos é de inteira responsabilidade do autor. 


\section{Sumário}

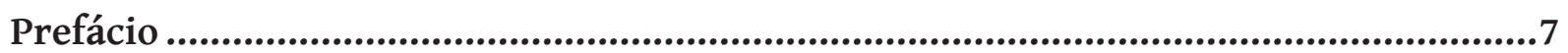

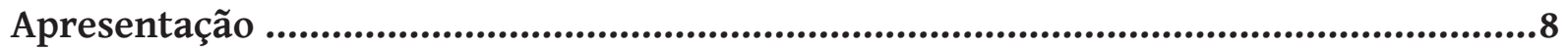

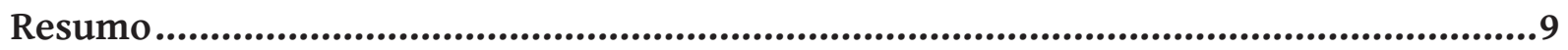

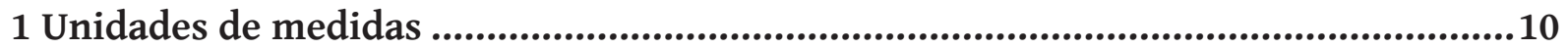

1.1 Organizando o Conceito de Medida ........................................................... 10

1.1.1 Como surgiram as primeiras unidades de medida? ................................. 10

1.2 Unidades de medida de comprimento ............................................................. 11

1.3 Outras unidades de medida de comprimento ................................................. 13

1.4 Unidades de medida de massa ................................................................ 13

1.5 Outras unidades de medida de massa ...................................................... 16

1.6 Unidades de medida de capacidade ...............................................................18

1.7 Unidades de medida de área ......................................................................... 19

1.8 Unidades de medida de volume ..............................................................20

1.9 Outras unidades de área: unidades agrárias ............................................21

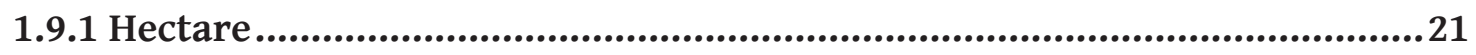

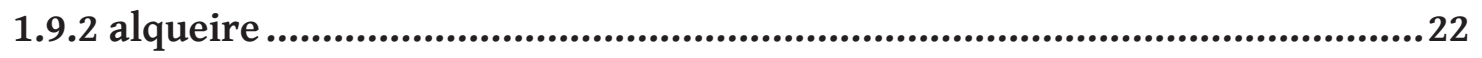

1.9.3 Litro ............................................................................................. 23

1.10 Unidades de medida utilizadas nas análises de solo e foliar ...................... 24

1.11 Problemas - Capítulo 1 ....................................................................................26

2 Geometria: perímetro, área e volume..................................................................31

2.1 Construções rurais ....................................................................................... 31

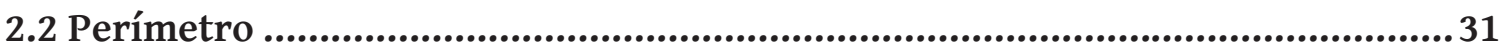

2.2.1 Perímetro de uma circunferência ....................................................... 33

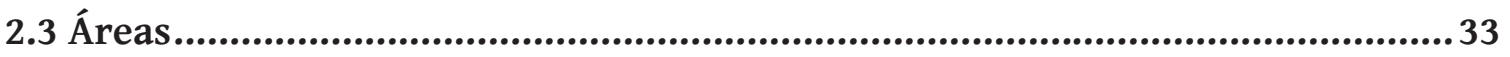

2.3.1 Área de uma região quadrada ..............................................................33

2.3.2 Área de uma região retangular .............................................................34

2.3.3 Área de uma região limitada por um paralelogramo.............................. 38

2.3.4 Área de uma região limitada por um triângulo ...................................... 38

2.3.5 Área de uma região limitada por um trapézio ...................................... 39

2.3.6 Área de uma região limitada por um losango ..................................... 40

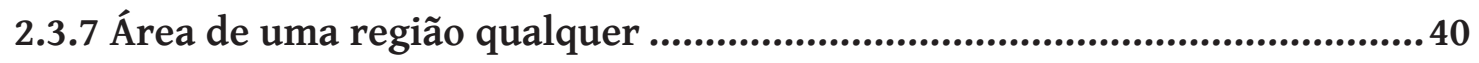

2.3.8 Área de uma região circular ........................................................... 41 


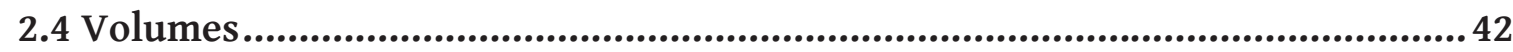

2.4.1 Volume de um cubo ...........................................................................42

2.4.2 Volume de um bloco retangular .............................................................. 43

2.4.3 Volume de um prisma reto qualquer ................................................. 44

2.5 Volume de um prisma reto retangular .........................................................46

2.6 Volume de um cilindro reto ......................................................................49

2.7 Volume de um cone ..........................................................................................49

2.8 Volume de uma pirâmide .......................................................................... 50

2.9 Volume de uma esfera......................................................................50

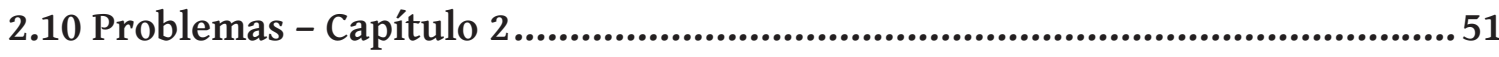

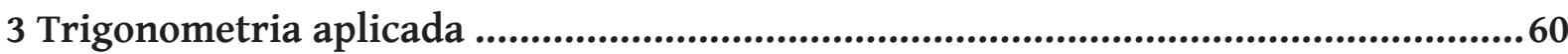

3.1 Noções preliminares..................................................................................... 60

3.2 Razões trigonométricas: seno, cosseno e tangente........................................60

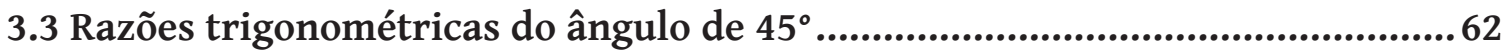

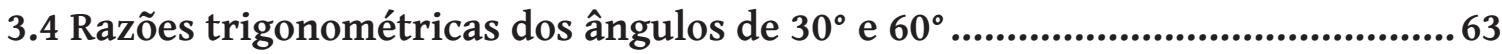

3.5 Trigonometria em um triângulo qualquer .................................................67

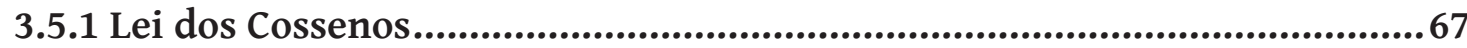

3.5.2 Lei dos Senos .......................................................................... 68

3.6 Problemas - Capítulo 3....................................................................... 70

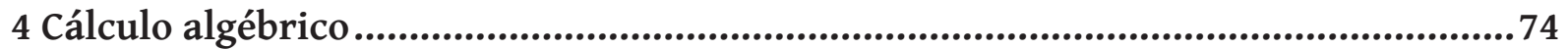

4.1 Razão e Proporção .............................................................................. 74

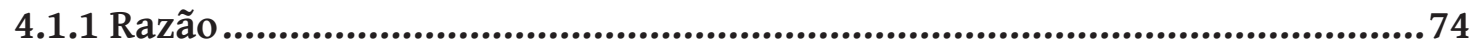

4.1.2 Proporção...................................................................................... 75

4.1.2.1 Propriedade Fundamental das Proporções .................................... 75

4.2 Grandezas Proporcionais .......................................................................... 75

4.2.1 Ideias Preliminares ............................................................................... 75

4.2.2 Grandezas Diretamente Proporcionais.................................................... 76

4.2.3 Grandezas Inversamente Proporcionais............................................. 76

4.3 Regra de Três...................................................................................... 77

4.3.1 Regra de Três Simples aplicada em situações de proporcionalidade direta .................................................................................77

4.3.2 Regra de Três Simples aplicada em situações de proporcionalidade inversa .....................................................................79

4.4 Regra de Três Composta.............................................................................8 80

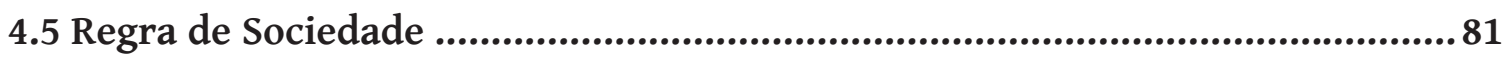


4.6 Porcentagem

4.7 Quadrado de Person com duas matérias primas para acerto de um nutriente 87

4.8 Problemas - Capítulo 4.........................................................................91

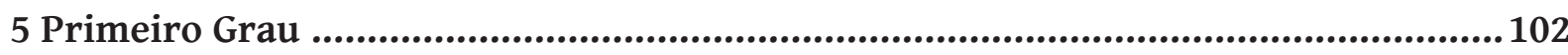

5.1 Equação do Primeiro Grau ..................................................................... 102

5.2 Resolução de problemas envolvendo equação do primeiro

grau relacionados a agropecuária

5.3 Sistema de Equações Lineares do $1^{\circ}$ Grau com duas

incógnitas e duas equações................................................................................ 104

5.3.1 Definição de um Sistema Linear 2X2 ........................................................... 104

5.3.2 Solução de um sistema Linear 2X2 ........................................................... 105

5.3.2.1 Método da substituição.................................................................. 105

5.3.2.2 Método da Eliminação .................................................................. 106

5.4 Método algébrico aplicado no balanceamento de ração com

dois alimentos/ingredientes para acerto de um nutriente ................................107

5.5 Problemas - Capítulo 5....................................................................... 109

6 Matemática Financeira Aplicada à Agroeconomia 111

6.1 Depreciação .................................................................................................... 111

6.2 Matemática Financeira .............................................................................. 114

6.2.2 Cálculo de juros em financiamento agropecuário.................................114

6.2.3 Taxas proporcionais não representam taxas equivalentes....................118

6.3 Problemas - Capítulo 6.................................................................... 121

7 Função polinomial do primeiro grau ...............................................................124

7.1 Noções Básicas sobre Função .................................................................. 124

7.2 Definiçãa de uma Função .......................................................................... 126

7.3 Gráfico de uma Função .............................................................................. 126

7.4 Função afim ............................................................................................... 127

7.5 Zero de uma Função Afim ...................................................................... 130

7.6 Construindo o gráfico de uma Função Afim .............................................. 130

7.7 Função Linear ..................................................................................... 131

7.8 Problemas - capítulo 7 ............................................................................... 133

8 Estatística Básica Aplicada na Análise de dados agropecuários............................ 135

8.1 Medidas de Tendência Central................................................................. 135

8.1.1 Média Aritmética ....................................................................... 135

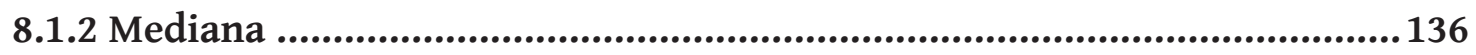


8.1.3 Moda

8.2 Medidas de Dispersão: Desvio Padrão.

8.1 Problemas - Capítulo 8

Referências bibliográficas.
137

140

.143 


\section{Prefácio}

Inicialmente, agradeço a honra e o privilégio da oportunidade de prefaciar a obra "Matemática Aplicada ao Ensino de Ciências Agrárias", visto que compartilhei com o autor o desafiador ambiente acadêmico de uma instituição de educação profissional tecnológica integrada ao ensino médio com ênfase ao ensino agrícola e pecuário, o qual exige maior aplicação dos conceitos no cotidiano profissional de seus educandos.

Esta obra é o resultado da experiência docente do autor, quando ministrou com competência e engajamento a disciplina de Matemática Aplicada, no curso Técnico em Agropecuária, da modalidade subsequente, no Instituto Federal do Espírito Santo, campus Itapina. Foi possível perceber um somatório de ações em sala de aula, a fim de tornar o ensino da matemática atrativamente compreensível e aplicável aos conceitos e habilidades de cálculo que fazem parte do ambiente de estudos das disciplinas dos núcleos básico e técnico.

Este material apresenta aos alunos, professores e interessados afins, claramente, em seus capítulos, os conceitos e definições, bem como, as aplicações materializadas na área agrária, com pertinentes e elucidativos exemplos, além de exercícios aplicáveis para a sedimentação da aprendizagem, descrevendo passo a passo, todos os procedimentos para a sua resolução.

É nossa expectativa que esta obra assuma forte influência no ensino da matemática nos cursos técnicos que pertencem às ciências agrárias, devido, principalmente, à sua abordagem didático-pedagógica. Assim sendo, a produção deste material permitirá desenvolver competências e habilidades em raciocínio lógico, crítico e analítico, transformando a matemática em uma disciplina de simples compreensão, útil e aplicável no cotidiano profissional.

Por fim, cumprimento o autor, professor Mateus Mendes Magela, pela inciativa e pela qualidade da obra "Matemática Aplicada ao Ensino de Ciências Agrárias", agradecendo por contribuir diretamente para a formação de profissionais cada vez mais competentes e, consequentemente, para uma educação pública de qualidade.

Professor Evandro Chaves de Oliveira Dr. Em Meteorologia Agrícola com ênfase em modelagem agrometeorologia. 


\section{Apresentação}

Este livro foi elaborado com foco nos alunos e professores de Matemática atuantes no curso Técnico em Agropecuária e demais cursos do Eixo Tecnológico Recursos Naturais. De acordo com o Catálogo Nacional de Cursos Técnicos $3^{a}$ edição do Ministério da Educação podemos destacar outros cursos técnicos favorecidos por este trabalho como: Agricultura, Agroecologia, Agronegócio, Aquicultura, Cafeicultura, Florestas, Fruticultura e Zootecnia. 0 objetivo principal deste livro é mostrar o modo como a Matemática está inserida no contexto dessas atividades econômicas e de que forma ela pode servir como ferramenta na formação técnica profissional do estudante.

Neste livro abordamos, de um modo aplicado, os principais temas em Matemática capazes de exercerem papel fundamental nas formações profissionais do Eixo Tecnológico Recursos Naturais. A abordagem temática foi utilizada como forma de possibilitar aos alunos desenvolver competência crítica a respeito da sua prática profissional.

A motivação para escrever este livro me ocorreu quando, no ano de 2015, ministrei uma disciplina de Matemática Aplicada no curso Técnico em Agropecuária na modalidade subsequente no Instituto Federal do Espírito Santo - campus Itapina, onde percebi que havia uma grande dificuldade por parte dos alunos para associar os conhecimentos matemáticos nas disciplinas do núcleo técnico.

A partir dessa percepção, passei a visitar as unidades de ensino do Campus a fim de buscar com os professores da área técnica informações a respeito de quais ferramentas matemáticas eram imprescindíveis para que os alunos pudessem avançar no núcleo técnico. Também busquei junto aos professores materiais de aulas e avaliações para que pudesse ter um embasamento aprofundado sobre o efetivo uso da Matemática nas disciplinas do núcleo técnico.

Acreditando na possibilidade de um novo olhar sobre a educação profissional, confio que este trabalho possa desempenhar um importante papel no desenvolvimento da educação profissional técnica agrícola no Instituto Federal do Espírito Santo e nas demais Instituições de Ensino Técnico no país. 


\section{Resumo}

Este livro aborda as ferramentas matemáticas fundamentais em seu contexto temático referente aos cursos Técnicos pertencentes ao Eixo Tecnológico Recursos Naturais. o público-alvo são os alunos do curso Técnico em Agropecuária, bem como alunos das ciências agrárias afins. Em cada um dos capítulos do livro são apresentados exemplos práticos, elucidando a teoria, que é desenvolvida em oito capítulos.

No capítulo 1, o leitor vai encontrar uma revisão de Unidades de Medidas e desenvolvimentos de alguns temas relacionados. No capítulo 2, é apresentado o tema da Geometria e suas aplicações nas Construções Rurais. 0 capítulo 3 aborda a Trigonometria, um importante assunto para o desenvolvimento da topografia. 0 capítulo 4 , traz de maneira bem detalhada os conceitos e aplicações da regra de três, uma importante ferramenta na formação profissional, e com diversas aplicações. No capítulo 5, é feita uma explanação dos sistemas de equações do primeiro grau com uma abordagem que substitui a aplicação do Quadrado de Person. 0 capítulo 6 aborda o tema da Matemática Financeira, imprescindível na formação do profissional quanto às habilidades necessárias para uma boa gestão rural. 0 capítulo 7 trabalha com o tema das Funções Polinomiais de Primeiro Grau, uma ferramenta indispensável na modelagem de fenômenos. E por fim, o capítulo 8 apresenta os conceitos básicos sobre Estatística, necessários para uma análise e interpretação de dados agrários.

O livro é composto com a exposição de exercícios resolvidos. Muitos desses são de nível elementar, e outros completam a teoria. Outros, ainda conduzem o estudante a adquirir um conhecimento matemático consistente. 


\section{Unidades de Medidas}

\subsection{Organizando o conceito de Medida}

Medir e comparar ou mensurar duas grandezas de mesma natureza, atribuindo à quantidade de vezes que uma contém a outra (unidade de medida).

Existem diversos instrumentos de medida, como réguas, balanças, termômetros, tais métricas, relógios, calendários, paquímetros, teodolito, barômetro, manômetro, voltímetro, trena, microscópios. 0 processo de medição pode ocorrer de modo direto ou indireto. Todo instrumento de medida, possui um valor de imprecisão.

\subsubsection{Como surgiram as primeiras Unidades de Medidas?}

Podemos estabelecer o desenvolvimento histórico das Unidades de Medidas em três períodos. 0 primeiro é denominado antropométrico. Nele, as pessoas realizavam as medições utilizando como unidade de medida as partes de seu próprio corpo, como o palmo, o passo, a polegada, o pé, o braço. Esse método era muito conveniente, pois os instrumentos de medida estavam ininterruptamente disponíveis. Porém, muitas desvantagens se sobrepunham a ele, como a dificuldade de medir objetos demasiadamente pequenos ou excessivamente grandes, além da ausência de uma padronização.

O segundo período é conhecido como ergométrico, e consistia na seleção de múltiplos e submúltiplos das unidades de medida adotadas no primeiro período. Com o desenvolvimento das cidades, das navegações e, especialmente, do comércio emergiu a necessidade de se adotar unidades de medidas convencionais e padronizadas.

Nesse sentido, a Revolução Francesa foi um acontecimento histórico definitivo para a padronização das unidades de medidas, a partir da qual ocorreu o terceiro e atual período da evolução das unidades de medida, chamado metrológico.

Muito importante foi a formação do Sistema Internacional de Unidades (SI), em 1960, na $11^{a}$ Conferência Geral de Pesos e Medidas (CGPM). Trata-se de um sistema decimal, composto por sete unidades fundamentais. Existem também unidades de medidas derivadas.

Tabela 1.1. Grandezas da base (SI)

\begin{tabular}{|c|c|c|}
\hline \multirow{2}{*}{ Grandezas de base } & \multicolumn{2}{|c|}{ Unidade de base (SI) } \\
\cline { 2 - 3 } & Nome & Símbolo \\
\hline Comprimento & Metro & $\mathrm{m}$ \\
\hline Massa & Quilograma & $\mathrm{Kg}$ \\
\hline Tempo & Segundo & $\mathrm{s}$ \\
\hline Intensidade de corrente elétrica & Ampere & $\mathrm{A}$ \\
\hline Temperatura termodinâmica & Kelvin & $\mathrm{K}$ \\
\hline Intensidade luminosa & Candela & $\mathrm{cd}$ \\
\hline Quantidade de matéria & Mole & $\mathrm{mol}$ \\
\hline
\end{tabular}




\subsection{Unidades de medida de comprimento}

De acordo com o Sistema Internacional, o metro (m), é a unidade base de medida de comprimento. Entretanto, existem outras unidades de comprimento derivadas do metro.

Observe a tabela a seguir.

Tabela 1.2 - Unidades de comprimento

\begin{tabular}{|c|c|c|c|c|c|c|}
\hline \multicolumn{3}{|c|}{ Múltiplos } & $\begin{array}{c}\text { Unidade } \\
\text { Padrão }\end{array}$ & \multicolumn{3}{c|}{ Submúltiplos } \\
\hline Quilômetro & Hectômetro & Decâmetro & Metro & Decímetro & Centímetro & Milímetro \\
\hline $\mathrm{Km}$ & $\mathrm{hm}$ & dam & $\mathrm{M}$ & $\mathrm{dm}$ & $\mathrm{cm}$ & $\mathrm{mm}$ \\
\hline $1000 \mathrm{~m}$ & $100 \mathrm{~m}$ & $10 \mathrm{~m}$ & $1 \mathrm{~m}$ & $0,1 \mathrm{~m}$ & $0,01 \mathrm{~m}$ & $0,001 \mathrm{~m}$ \\
\hline
\end{tabular}

Observe que cada unidade de comprimento equivale a 10 vezes a unidade imediatamente localizada a sua direita.

Exemplo 1.2.1 Transformar 2.145 metros em centímetros.

Resolução: Primeiro vamos transformar de metros para decímetros.

$$
2145 \times 10=21450
$$

Agora, vamos transformar de decímetro para centímetro.

$$
21450 \times 10=214500
$$

Portanto, 2145 m correspondem a $214450 \mathrm{~cm}$. Note que, esta transformação, poderia ter sido realizada com uma única operação.

$$
2145 \times 100=214500
$$

Exemplo 1.2.2 Transformar 274 hectômetros em quilômetros.

Resolução: Basta realizarmos uma operação de transformação para a esquerda.

$$
274: 10=27,4
$$

Portanto, 274 hectômetros equivalem a 27,4 km.

Exemplo 1.2.3 Para o cultivo de mamão, um pequeno agricultor vai utilizar todo um terreno retangular de dimensões de $6 \mathrm{~km}$ por $6 \mathrm{~km}$. Utilizando um espaçamento de $3 \mathrm{~m}$ por $3 \mathrm{~m}$ em plantio de alinhamento quadrado. Quantas plantas ele irá plantar em cada fileira?

Resolução: Primeiro passo é padronizar as unidades de medida. Nesse caso, vamos 
transformar as dimensões do terreno dadas em $\mathrm{km}$ para $\mathrm{m}$. Sabendo que, o metro está localizado três casas à direita do quilômetro podem realizar essa transformação com uma única operação:

$$
6 \times 1000=6000
$$

Logo, em cada fileira serão plantadas:

$$
6000: 3=200
$$

Portanto, serão plantadas 200 plantas por fileira.

\subsection{Outras unidades de medida de comprimento}

Alguns países como Inglaterra e Estados Unidos não utilizam inteiramente o SI. Nesses países, também são utilizadas como unidades de medidas de comprimento o pé, a polegada, a jarda e a milha terrestre.

Tabela 1.3 - Outras unidades de medida de comprimento

\begin{tabular}{|c|c|}
\hline 1 pé & $30,48 \mathrm{~cm}$ \\
\hline 1 polegada & $2,54 \mathrm{~cm}$ \\
\hline 1 jarda & $91,44 \mathrm{~cm}$ \\
\hline 1 milha terrestre & $1609 \mathrm{~m}$ \\
\hline
\end{tabular}

No Brasil usamos algumas dessas unidades de medida. Por exemplo, determinamos o comprimento da tela de uma TV ou computador, as dimensões de encalhamento, de parafusos e de algumas ferramentas, polegadas.

Exemplo 1.3.1 Observe as relações de equivalências:

- 8 milhas terrestres $=8 \times 1609 \mathrm{~m}=12872 \mathrm{~m}$.

- 1 pé $=12 \times 2,54 \mathrm{~cm}=12$ polegadas.

- 40 polegadas $=40 \times 2,54=100,16 \mathrm{~cm}$. 


\subsection{Unidades de medida de massa}

Primeiro, é importante ressaltar que massa é diferente de peso. Embora essas duas palavras sejam usadas no cotidiano com o mesmo significado, elas representam grandezas distintas. Massa está relacionada com a quantidade de matéria. Portanto, o correto seria dizer: "essa saca de café é de 60 quilogramas". Por outro lado, peso está relacionado com a intensidade com que a gravidade atua sobre um corpo. Assim, o peso de uma saca de café na Terra é diferente do seu peso na Lua.

No SI, a unidade padrão de massa, é o quilograma $(\mathrm{kg})$, mas na prática, por conveniência, usamos o grama (g). Entretanto, existem outras unidades de massa derivadas do quilograma. Observe a tabela.

Tabela 1.4 - Unidades de medida de massa

\begin{tabular}{|c|c|c|c|c|c|c|}
\hline \multicolumn{3}{|c|}{ Múltiplos } & $\begin{array}{c}\text { Unidade } \\
\text { Padrão }\end{array}$ & \multicolumn{3}{c|}{ Submúltiplos } \\
\hline Quilograma & Hectograma & Decagrama & Grama & Decigrama & Centigrama & Miligrama \\
\hline $\mathrm{Kg}$ & $\mathrm{hg}$ & $\mathrm{dag}$ & $\mathrm{g}$ & $\mathrm{dg}$ & $\mathrm{cg}$ & $\mathrm{mg}$ \\
\hline $1000 \mathrm{~g}$ & $100 \mathrm{~g}$ & $10 \mathrm{~g}$ & $1 \mathrm{~g}$ & $0,1 \mathrm{~g}$ & $0,01 \mathrm{~g}$ & $0,001 \mathrm{~g}$ \\
\hline
\end{tabular}

Observe que cada unidade de massa equivale a 10 vezes a unidade imediatamente localizada a sua direita.

Exemplo 1.4.1 Transformar 5,678 decagramas em gramas.

Resolução: Como o grama está localizado imediatamente à direita do decagrama, basta realizarmos uma operação de transformação.

$$
5,678: 10=56,78
$$

Portanto, 5,678 dag equivalem a 56,78 g.

Exemplo 1.4.2 Transformar 3400 gramas em quilogramas.

Resolução: Primeiro vamos transformar de gramas para decagramas.

$$
3400: 10=340 .
$$

Agora, vamos transformar 340 decagramas para hectogramas.

$$
340: 10=34 \text {. }
$$

E, finalmente, vamos transformar $34 \mathrm{hg}$ para quilogramas. 


$$
34: 10=3,4
$$

Portanto, 3400 gramas equivalem a $3,4 \mathrm{~kg}$.

Essa transformação, também pode ser realizada com apenas uma operação.

$$
3400: 1000=3,4 \text {. }
$$

Exemplo 1.4.3 Após uma negociação com um cliente, ficou acertado que ele vai comprar $325 \mathrm{~kg}$ de filé de tilápia por semana. De acordo com o planejamento, qual a quantidade total de tilápia necessária para atender o cliente, sabendo que o filé deve ter $100 \mathrm{~g}$ de massa?

Resolução: Inicialmente, vamos transformar $325 \mathrm{~kg}$ em gramas.

$$
325 \times 1000=325000
$$

Sabemos que, cada exemplar de Tilápia produz dois filés. Com efeito,

$$
325000: 200=1625 \text {. }
$$

Portanto, são necessários 1625 peixes.

Exemplo 1.4.4 Operações para impedir a extinção de peixes nativos em bacias hidrográficas é uma atividade lucrativa para criadores. A introdução de peixes em rios, lagos e represas é uma prática realizada no Brasil desde 1970. Muitas vezes, é adotada para mitigar os impactos das construções de barragens e do crescimento da poluição e da pesca predatória, principais fatores que ameaçam de extinção as espécies nativas de bacias hidrográficas do país.

Fonte: MATHIAS, João. Como repovoar os rios. Revista GloboRural n. 363, p. 17-19, 2016.

Para reduzir os danos provocados por um desastre ambiental em um rio, foi realizado um repovoamento com 60 mil unidades de peixes, com uma média de $800 \mathrm{~g}$ cada. Calcule o valor total, em quilogramas, da biomassa descarregada nesse rio.

Resolução: O valor total da biomassa é dado por:

$$
(800 \mathrm{~g}) \times(60000)=48000000 \mathrm{~g} \text {. }
$$

Agora, vamos transformar esse valor em gramas para quilogramas.

$$
48000000: 1000=48000 \text {. }
$$


Portanto, o valor total da biomassa descarregada foi de $48000 \mathrm{~kg}$.

\subsection{Outras Unidades de Massa}

Para medir grandes massas, podemos utilizar outras unidades tais como a arroba e a tonelada.

- 1 arroba $(@)=15 \mathrm{~kg}$

- 1 tonelada $(\mathrm{t})=1.000 \mathrm{~kg}$

Exemplo 1.5.1 De acordo com a Coordenação Geral de Organização para Exportação (CGOE), da Secretaria de Relações Internacionais (SRI), as exportações brasileiras de carne bovina no mês de agosto de 2015, atingiram aproximadamente $112400000 \mathrm{~kg}$, a um preço médio de 4427 dólares a tonelada. Com base nesses dados, qual é o valor total, em dólares, gerado pela exportação brasileira de carne bovina nesse período?

Resolução: Inicialmente, vamos transformar a quantidade exportada de quilogramas para toneladas.

$$
112400000: 1000=112400
$$

Agora, vamos determinar o valor total em dólares.

$$
112400 \times 4427=497594800
$$

Portanto, as exportações brasileiras de carne bovina no mês de agosto de 2015 geraram um montante de 497594800 dólares.

Exemplo 1.5.2 Devido a um forte período de seca, em 2014, o Brasil registrou uma redução de 6,4 milhões de sacas de café.

Fonte: Revista PROCAMPO, n - 58, out./nov. 2015.

Sabendo que uma saca de café equivale a $60 \mathrm{~kg}$. Qual foi a redução, em toneladas, na produção de café no Brasil em 2014?

Resolução: Primeiro vamos determinar quantos quilogramas equivalem a 6,4 milhões de sacas.

$$
6400000 \times 60=384000000
$$


Agora vamos transformar de quilogramas em toneladas.

$$
384000000: 1000=384000 .
$$

Portanto, em 2014, foi registrada uma redução de 384 mil toneladas na produção de café.

Exemplo 1.5.2 Pedro comprou 16 arrobas de soja e pagou $\mathrm{R} \$ 55,00$ a arroba. Em seguida, vendeu toda a soja comprada por $\mathrm{R} \$ 8,00$ o quilograma. Qual foi o lucro de Pedro nessa negociação?

Resolução: Primeiro vamos calcular o valor investido por Pedro.

$$
16 \times 55=880 \text {. }
$$

Portanto, Pedro investiu R $\$ 880,00$.

Agora vamos calcular o valor arrecadado, em reais, após a venda da soja.

$$
\begin{aligned}
16 \times 15 & =250 \\
250 \times 8 & =2000
\end{aligned}
$$

Logo, Pedro arrecadou após a venda o valor de $\mathrm{R} \$ 2000,00$.

$$
2000-880=1120
$$

O lucro de Pedro nessa negociação foi de $\mathrm{R} \$ 1$ 120,00.

\subsection{Unidades de medida de capacidade}

Capacidade é uma grandeza que mede a quantidade de gás ou líquido que cabe em um recipiente. A unidade padrão é o litro (l). Observe na tabela que cada unidade de capacidade equivale a 10 vezes a unidade imediatamente localizada a sua direita.

Tabela 1.6: Unidades de medida de capacidade

\begin{tabular}{|c|c|c|c|c|c|c|}
\hline \multicolumn{3}{|c|}{ Múltiplos } & $\begin{array}{c}\text { Unidade } \\
\text { Padrão }\end{array}$ & \multicolumn{3}{c|}{ Submúltiplos } \\
\hline Quilolitro & Hectolitro & Decalitro & Litro & Decilitro & Centilitro & Mililitro \\
\hline $\mathrm{Kl}$ & $\mathrm{hl}$ & $\mathrm{dal}$ & $\mathrm{l}$ & $\mathrm{dl}$ & $\mathrm{cl}$ & $\mathrm{ml}$ \\
\hline $1000 \mathrm{l}$ & $100 \mathrm{l}$ & $10 \mathrm{l}$ & $1 \mathrm{l}$ & $0,1 \mathrm{l}$ & $0,01 \mathrm{l}$ & $0,001 \mathrm{l}$ \\
\hline
\end{tabular}


Exemplo 1.6.1 Transformar 250 mililitros em litros

Resolução: Inicialmente vamos transformar de mililitros para centilitros.

$$
250: 10=25
$$

Em seguida vamos transformar de centilitros para decilitros.

$$
25: 10=2,5
$$

E, por fim, transformamos de decilitros para litros.

$$
2,50: 10=0,25
$$

Portanto $250 \mathrm{ml}$ equivalem a 0,25 l. Essa transformação pode ser realizada com uma única operação.

$$
250: 1000=0,250
$$

\subsection{Unidades de medida de área}

A unidade padrão de acordo com o SI é o metro quadrado $\left(\mathrm{m}^{2}\right)$. Observem, na tabela, os múltiplos e submúltiplos do metro quadrado.

Tabela 1.7 - Unidades de medida de área

\begin{tabular}{|c|c|c|c|c|c|c|}
\hline \multicolumn{3}{|c|}{ Múltiplos } & $\begin{array}{c}\text { Unidade } \\
\text { Padrão }\end{array}$ & \multicolumn{3}{c|}{ Submúltiplos } \\
\hline $\mathrm{km}^{2}$ & $\mathrm{hm}^{2}$ & $\mathrm{dam}^{2}$ & $\mathrm{~m}^{2}$ & $\mathrm{dm}^{2}$ & $\mathrm{~cm}^{2}$ & $\mathrm{~mm}^{2}$ \\
\hline $1.000 .000 \mathrm{~m}^{2}$ & $10.000 \mathrm{~m}^{2}$ & $100 \mathrm{~m}^{2}$ & $1 \mathrm{~m}^{2}$ & $0,01 \mathrm{~m}^{2}$ & $0,0001 \mathrm{~m}^{2}$ & $0,000001 \mathrm{~m}^{2}$ \\
\hline
\end{tabular}

Exemplo 1.7.1 Transformar 2,5 metros quadrados em centímetros quadrados.

Resolução: Primeiro vamos transformar de metros quadrados para decímetros quadrados.

$$
2,5 \times 100=250
$$

Portanto 2,5 m2 equivalem a $250 \mathrm{~cm} 2$. Agora vamos transformar de decímetros quadrados para centímetros quadrados. 


$$
250 \times 100=25000
$$

Esta transformação pode ser feita usando uma única operação.

$$
2,5 \times 10000=25000
$$

Portanto 2,5 metros quadrados equivalem a 25000 centímetros quadrados.

\subsection{Unidades de medida de volume}

Volume é uma grandeza que mede o espaço ocupado. A unidade padrão é o metro cúbico (m3).

Tabela 1.8 - Unidades de medida de volume

\begin{tabular}{|c|c|c|c|c|c|c|}
\hline \multicolumn{3}{|c|}{ Múltiplos } & $\begin{array}{c}\text { Unidade } \\
\text { Padrão }\end{array}$ & \multicolumn{3}{c|}{ Submúltiplos } \\
\hline $\mathrm{km}^{3}$ & $\mathrm{hm}^{3}$ & $\mathrm{dam}^{3}$ & $\mathrm{~m}^{3}$ & $\mathrm{dm}^{3}$ & $\mathrm{~cm}^{3}$ & $\mathrm{~mm}^{3}$ \\
\hline $1000000000 \mathrm{~m}^{3}$ & $1000000 \mathrm{~m}^{3}$ & $1000 \mathrm{~m}^{3}$ & $1 \mathrm{~m}^{3}$ & $0,001 \mathrm{~m}^{3}$ & $0,000001 \mathrm{~m}^{3}$ & $0,000000001 \mathrm{~m}^{3}$ \\
\hline
\end{tabular}

É possível relacionarmos as unidades de medida de capacidade com as unidades de medida de volume.

- $\quad 1 \mathrm{dm}^{3}=1$ litro.

- $1 \mathrm{~m}^{3}=1000$ litros.

Exemplo 1.8.1 Transformar 10,5 metros cúbicos em centímetros cúbicos.

Resolução: Inicialmente vamos transformar metros cúbicos em decímetros cúbicos.

$$
10,5 \times 1000=10500 .
$$

Em seguida, transformamos 10500 decímetros cúbicos para centímetros cúbicos.

$$
10500 \times 1000=10500000 .
$$

Portanto 10,5 $\mathrm{m}^{3}$ equivalem a $10500000 \mathrm{~cm}^{3}$.

Exemplo 1.8.2 Quantos litros de água cabem em um reservatório com volume igual a $2000 \mathrm{~m}^{3}$ ? 


\section{Resolução:}

$$
2000 \times 1000=2000000 .
$$

Portanto, em um reservatório com volume de $2000 \mathrm{~m}^{3}$, cabem 2000000 de litros de água.

\subsection{Outras unidades de área: unidades agrárias}

\subsubsection{Hectare.}

O hectômetro quadrado $\left(\mathrm{hm}^{2}\right)$ também é chamado de hectare (ha).

$$
1 \text { ha }=10000 \mathrm{~m}^{2}
$$

O hectare é comumente usado para representar medidas agrárias.

Exemplo 1.9.1.1 João comprou 20 hectares de terra em Marilândia (ES). Ele usou metade dessa área para plantar café. Quantos metros quadrados ainda restaram na propriedade do João?

Resolução: Como João usou apenas metade do terreno disponível, vamos transformar 10 hectares para metros quadrados.

$$
10 \times 10000=100000
$$

Portanto, ainda restam $100000 \mathrm{~m}^{2}$.

Exemplo 1.9.1.2 A integração do Reflorestar com o programa Águas e Paisagens irá permitir, ainda, o atendimento de cerca de mil propriedades rurais localizadas nos municípios das bacias do Jucu, do rio Santa Maria da Vitória e na região do Caparaó Capixaba, possibilitando a implantação de práticas florestais sustentáveis em cerca de 3,8 hectares.

Fonte: Revista PROCAMPO ano XI, n. - 58, - out./nov- 2015.

De acordo com o texto, qual é, em quilômetros quadrados, a área destinada à implantação de práticas florestais sustentáveis?

Resolução: Inicialmente, vamos transformar de hectares para metros quadrados.

$$
3,8 \times 10000=38000
$$


Portanto, 3,8 ha equivalem a $38000 \mathrm{~m}^{2}$.

Agora, vamos transformar de metros quadrados para quilômetros quadrados. Essa transformação pode ser realizada usando apenas uma operação. Basta observar que o quilômetro quadrado, está localizado na terceira casa à esquerda do metro quadrado, então para cada casa à esquerda, devemos efetuar uma divisão por 100. Como são três casas, resolvemos de modo direto, dividindo por 1000000.

$$
38000: 1000000=0,038 .
$$

Portanto, a área destinada à implantação de práticas florestais sustentáveis corresponderá a $0,038 \mathrm{~km}^{2}$.

\subsubsection{0 alqueire}

Outra medida agrária bastante utilizada é o alqueire. Diferente de outras unidades de medida, o alqueire não é padronizado, cada região do Brasil possui uma relação.

- Alqueire paulista $=24200 \mathrm{~m}^{2}$

- Alqueire mineiro $=48400 \mathrm{~m}^{2}$.

- Alqueire capixaba $=30976 \mathrm{~m}^{2}$

- Alqueire baiano $=96800 \mathrm{~m}^{2}$

Exemplo 1.9.2.1 Examine o anúncio abaixo publicado em um jornal de Minas Gerais.

Vendo sítio de 2 alqueires, cercado c/alambrado, casarão centenário.

Quantos metros quadrados possui esse sítio?

Resolução: Como o terreno em questão está localizado em Minas Gerais, vamos usar $o$ alqueire mineiro.

$$
2 \times 48400=96800
$$

Portanto, o sítio possui $96800 \mathrm{~m}^{2}$. 


\subsubsection{O litro}

É possível verificar que as atividades do campo estão carregadas de boa matemática. Por meio delas, é possível aplicarmos conceitos matemáticos e, o mais interessante, é podemos instituir novos usos para alguns conhecimentos, a exemplo do litro.

o litro é definido como unidade de medida de capacidade, porém, no campo, pode-se utilizá-lo como unidade de medida de área. Essa sua nova forma de uso traz muita praticidade para o registro no plantio de grãos, como o milho e o feijão, principalmente para a agricultura familiar ou de baixa escala. Para medirmos a extensão de terra por meio do litro, enchemos com sementes um recipiente de 1 litro de capacidade e colocamos 5 ou 6 grãos por cova. A área plantada com todas as sementes é denominada 1 litro de terra. Essa medida não é precisa, pois varia de acordo com o número de grãos por cova e o tamanho do grão. Usualmente, 1 litro de área equivale a $600 \mathrm{~m}^{2}$.

Exemplo 1.9.3.1 Qual é a área aproximada de um terreno ocupado com 3,5 litros de milho plantados?

\section{Resolução:}

$$
3,5 \times 600=2100 .
$$

Portanto, o terreno possui $2100 \mathrm{~m}^{2}$ ocupados com a plantação.

\subsection{Unidades de medida utilizadas nas análises de solo e foliar}

São citadas a seguir algumas unidades de medida usadas para facilitar a interpretação das análises de solo e foliar.

- $\%=\mathrm{dag} / \mathrm{kg}$

- $\mathrm{ppm}=\mathrm{mg} / \mathrm{dm}^{3}=\mathrm{mg} / \mathrm{kg}=\mathrm{mg} / \mathrm{L}$

Fonte: PREZOTTI, L.C. Sistema de recomendação de calagem e adubação. Disponível em: http:www.incaper.es.gov

Exemplo 1.10.1 Numa análise de solo, o teor de matéria orgânica encontrado foi de $50 \mathrm{~g} / \mathrm{kg}$. Considerando essa análise, qual é a porcentagem de matéria orgânica nesse solo?

Resolução: Primeiro, vamos transformar de grama para decagrama. 
Portanto, $50 \mathrm{~g}=5 \mathrm{dag}$.

Então, a porcentagem de matéria orgânica presente na amostra é de $5 \mathrm{dag} / \mathrm{kg}$, isto é, $5 \%$.

Exemplo 1.10.2 Observe a seguir uma análise de solo realizada por um produtor de batata-doce.

$$
\begin{aligned}
& \text { Análise: } \\
& \begin{array}{l}
\mathrm{P}=80 \mathrm{cg}=\mathrm{dm}^{3} \\
\mathrm{~K}=15 \mathrm{cg}=\mathrm{dm}^{3} \\
\mathrm{~V}=40 \%
\end{array}
\end{aligned}
$$

De acordo com a classe de interpretação para potássio indicada abaixo, a amostra de solo está em qual classificação?

Tabela 1.10.1 - Classe de interpretação para potássio disponível em função da cultura

\begin{tabular}{|c|c|c|c|c|c|c|}
\hline \multicolumn{2}{|c|}{ Determinação } & Unidade & Cultura & \multicolumn{3}{c|}{ Classificação } \\
\hline \multirow{2}{*}{} & & & Baixo & Médio & Alto \\
\hline \multirow{2}{*}{ Potássio } & \multirow{2}{*}{$(\mathrm{K})$} & \multirow{2}{*}{$\mathrm{mg} / \mathrm{dm} 3$} & Perene / Anual & $<60$ & $60-150$ & $>150$ \\
\cline { 4 - 7 } & & Hortaliça & $<80$ & $80-200$ & $>200$ \\
\hline
\end{tabular}

Fonte: PREZOTTI, L.C. Sistema de recomendação de calagem e adubação. Disponível em: http:www.incaper.es.gov

Resolução: Como podemos observar, a unidade para classificação do potássio é mg/ dm3. Então, devemos transformar o resultado da análise de $\mathrm{cg} / \mathrm{dm}^{3}$ para $\mathrm{mg} / \mathrm{dm}^{3}$.

$$
15 \times 10=150 .
$$

Assim, a análise realizada indica uma concentração de $150 \mathrm{mg} / \mathrm{dm}^{3} \mathrm{de} \mathrm{K}$. Portanto, de acordo com a classificação, temos um nível médio de $\mathrm{K}$ no solo.

\subsection{Problemas - Capítulo 1}

Problema 1.11.1 O estado do Espírito Santo consome aproximadamente R \$ 10000 000,00 em uva, sendo essa a terceira fruteira, em valores, mais consumida. A maior parte da uva de mesa vem dos estados do Paraná, São Paulo, Bahia e Pernambuco. Portanto, uma produção local poderá reduzir o envio de recursos para outros estados, ampliando a 
geração de empregos no campo, assim como uma nova oportunidade de renda. Em 10000 $\mathrm{m}^{2}$ é possível produzir $30000 \mathrm{~kg}$ por ano em duas safras.

Fonte: Revista PROCAMPO, n.31, (abr./mai) 2011.

De acordo com o texto responda.

(a) Daniel, um agricultor, decidiu investir no promissor mercado de uva do Espírito Santo. Para isso, ele destinou uma área de $60000 \mathrm{~m}^{2}$ para o plantio em sua propriedade. Qual é, em toneladas, a produção esperada por ano?

(b) Sabendo que Daniel irá vender toda a sua produção em caixas contendo 15 kg de uva cada. Quantas caixas serão necessárias para a sua produção?

Problema 1.11.2 Transformar 542145 metros em centímetros.

Problema 1.11.3 Transformar 274 hectômetros em quilômetros.

Problema 1.11.4 Para o cultivo de goiaba, um pequeno agricultor vai utilizar todo um terreno retangular de dimensões de $12 \mathrm{~km}$ por $12 \mathrm{~km}$. Utilizando um espaçamento de $3 \mathrm{~m}$ por $3 \mathrm{~m}$ em plantio de alinhamento quadrado. Quantas plantas ele irá plantar em cada leira?

Problema 1.11.5 Em 2 metros há quantas polegadas, aproximadamente?

Problema 1.11.6 Em $12872 \mathrm{~km}$ há quantas milhas terrestres, aproximadamente?

Problema 1.11.7 Em 804,5 metros há quantos quilômetros?

Problema 1.11.8 Em 1 milha terrestre há quantas jardas, aproximadamente?

Problema 1.11.9 Sabendo que $1 \mathrm{~g}$ de semente de mamão corresponde a 60 sementes. Quantas sementes de mamão existem em $1 \mathrm{~kg}$ de sementes?

Problema 1.11.10 Complete.
(a) $3,4 \mathrm{~m} 2=\ldots \mathrm{dm}^{2}$
(b) $3200 \mathrm{~m} 2=\ldots \mathrm{hm}^{2}$
(c) $5,5 \mathrm{~cm} 2=\ldots \mathrm{dm}^{2}$
(d) $2,1 \mathrm{~km} 2=\ldots \mathrm{cm}^{2}$

Problema 1.11.11 o governo do estado do Espírito Santo, através da Secretaria de Estado da Agricultura, Abastecimento, Aquicultura e Pesca, anunciou a construção de 32 
barragens para o armazenamento de água no interior do estado. As barragens terão capacidade para armazenar 19,5 milhões de litros.

Fonte: Revista PROCAMPO, ANO XI, n. - 58, (out./nov) 2015.

(a) Qual é, em quilolitros, a capacidade de armazenamento das 32 barragens?

(b) Somada à construção das barragens, as novas diretrizes adotadas pelo governo do estado no Planejamento Estratégico 2015 - 2018 para as áreas de meio ambiente e agricultura preveem a ampliação da cobertura vegetal em 80 mil hectares. Quanto representa essa ampliação em quilômetros quadrados?

Problema 1.11.12 Um caminhão pode transportar uma carga de, no máximo, 5,3 toneladas. Esse caminhão pode transportar:

(a) 55 caixas com $95 \mathrm{~kg}$ cada uma? Justifique sua resposta.

(b) 65 caixas com $85 \mathrm{~kg}$ cada uma? Justifique sua resposta.

Problema 1.11.13 Aldair, que é um fazendeiro, deseja construir um cercado para seu pomar. Sabe-se que, para dar uma volta completa, ele irá gastar 600m de arame. E, para realizar essa tarefa, Aldair irá dar 5 voltas completas em seu pomar. De quantos km de arame ele deverá dispor?

Problema 1.11.14 Silagem é o produto oriundo da conservação de forragens úmidas (planta inteira) ou de grãos de cereais com alta umidade (grão úmido) através da fermentação em meio anaeróbico, ambiente isento de oxigênio, em locais denominados silos.

Fonte: AGROCERES, Sementes.

Disponível em: www.sementesagroceres.com.br/pages/Silagem.aspx

Os silos mais utilizados são os horizontais, cujo formato é o de um prisma reto trapezoidal.

Após a silagem, 1 tonelada de forragem ocupa $2 \mathrm{~m}^{3}$ desse tipo de silo.

(a) Após a silagem, a quantidade máxima de forragem que cabe em um silo horizontal de $0,5 \mathrm{~km}^{3}$, em toneladas, é?

(b) Sabendo que um silo horizontal possui 40.000 hg de capacidade máxima de forragem após a silagem. Qual é, em $\mathrm{m}^{3}$, o dimensionamento desse silo?

Problema 1.11.15 Complete.
(a) $3,45 \mathrm{~m} 3=\ldots \mathrm{dm}^{3}$
(b) $20.000 \mathrm{~m} 3=\ldots \mathrm{hm}^{3}$
(c) $0,0012 \mathrm{~m} 3=\ldots \mathrm{cm}^{3}$
(d) $400 \mathrm{~mm} 3=\ldots \mathrm{dm}^{3}$ 
Problema 1.11.16 Transformar 467,5 hectolitros em centilitros.

Problema 1.11.17 Transformar 45.000 l em decâmetros cúbicos.

Problema 1.11.18 Complete.
(a) $5 \mathrm{l}=\ldots \mathrm{ml}$
(b) $87,2 \mathrm{kl}=\ldots 1$

Problema 1.11.19 Considere um plantio de 2 ha de milho nos espaçamentos $2 \times 2 \times 2$ $\mathrm{m}$, bem como a utilização de 5 sementes por cova. Sabendo que $1 \mathrm{~g}$ de grãos equivale a 3 grãos. Calcule:
(a) Número de covas na área inicial do plantio de 2 ha.
(b) Número de sementes necessário para o plantio de 2 ha
(c) Quantidade de sementes, em quilogramas, para o plantio de 2 ha.

Problema 1.11.20 Alice comprou 33 hectares de terra em Linhares (ES). Ela usou um terço dessa área para plantar cacau. Quantos metros quadrados ainda restaram na propriedade de Alice?

Problema 1.11.21 Aponte as vantagens e desvantagens da utilização do litro como unidade de medida de área.

Problema 1.11.22 Qual é a área aproximada de um terreno ocupado com 20,5 litros de milho plantados?

Problema 1.11.23 Um produtor irá cultivar café em uma área de 20 ha, com espaçamento de 4 metros entre linhas e 1 metro entre plantas. Qual é a quantidade de mudas necessárias para os 20 ha?

Problema 1.11.24 Um agricultor precisa aplicar $80 \mathrm{~kg}$ de ureia por hectare, para restabelecer o potencial produtivo de uma área retangular com dimensões de $400 \mathrm{~m} \times 3 \mathrm{~km}$. Sabendo que o fertilizante nitrogenado a ser aplicado pelo agricultor possui um custo de $\mathrm{R} \$ 880,00$ a tonelada. Qual será o valor total gasto pelo agricultor?

Problema 1.11.25 Um pecuarista possui um rebanho de 2000 cabeças de gado bovino numa propriedade retangular com dimensões de $6 \mathrm{~km}$ por $8000 \mathrm{~m}$. Qual é a pressão de pastejo, isto é, o número de animais por hectare? 
Problema 1.11.26 Numa análise de solo, o teor de matéria orgânica encontrado foi de $150 \mathrm{~g} / \mathrm{kg}$. Considerando essa análise, qual é a porcentagem de matéria orgânica nesse solo?

Problema 1.11.27 Observe a seguir uma análise de solo.

Análise:
$\begin{aligned} & \mathrm{P}=90 \mathrm{mg} / \mathrm{dm} 3 \\ & \mathrm{~K}=0,12 \mathrm{~g} / \mathrm{dm} 3 \\ & \mathrm{~V}=30 \%\end{aligned}$
De acordo com a classe de interpretação para potássio, a amostra desse solo indica
qual classificação?




\section{Geometria: perímetro, área e volume}

\subsection{Construções rurais}

As construções rurais exercem papel fundamental nas atividades agrícolas. Por meio delas, é possível planejar o dimensionamento de projetos estruturais, aplicar com maior eficiência técnicas de acondicionamento térmico natural ou artificial das instalações, construção de silos para a fabricação de forragem, construção de viveiros, construção de instalações para animais e construção de estruturas para o armazenamento e beneficiamento da produção. As construções rurais visam o aumento da produtividade por meio do uso de técnicas de otimização da produção. Por essas características, é indispensável o domínio sobre os conhecimentos de geometria, afim de aplicá-los na execução dos projetos de maneira mais adequada. Nesse capítulo, vamos apresentar os conhecimentos em geometria essenciais para a elaboração e execução de projetos de instalações agrícolas.

\subsection{Perímetro}

Perímetro é a medida do comprimento do contorno de uma figura plana.

Exemplo 2.2.1 Alessandra deseja instalar uma cerca, do tipo alambrado, no pasto onde está seu rebanho de gado de leite. 0 pasto tem forma retangular de dimensões $100 \mathrm{~m}$ por $140 \mathrm{~m}$. Ela pretende por um mourão a cada 30 metros para prender a cerca. De quantos metros de cerca e de quantos mourões Alessandra irá precisar?

Resolução: Inicialmente vamos representar graficamente (croqui) a situação-problema.

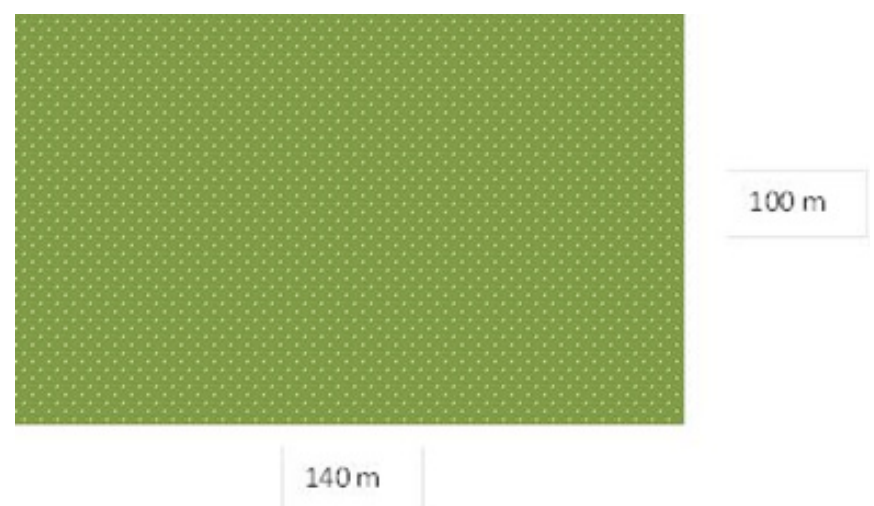

Figura 2.2.1 - Terreno Retangular (Pasto)

O terreno acima tem a forma retangular com lados medindo $100 \mathrm{~m}, 140 \mathrm{~m}, 100 \mathrm{~m}$ e $140 \mathrm{~m}$. 
Seu perímetro P é calculado da seguinte forma:

$$
\mathrm{P}=100+140+100+140=480
$$

Portanto Alessandra irá precisar de 480 metros de alambrado. Agora, como a cada 30 metros ela irá instalar um mourão, fazemos:

$$
480: 30=18
$$

Então, ela irá precisar de 18 mourões.

Exemplo 2.2.2 A figura a seguir representa um croqui localizando um plantio de mamão no espaçamento $3 \mathrm{~m} \times 3 \mathrm{~m}$, num alinhamento tipo quadrado.

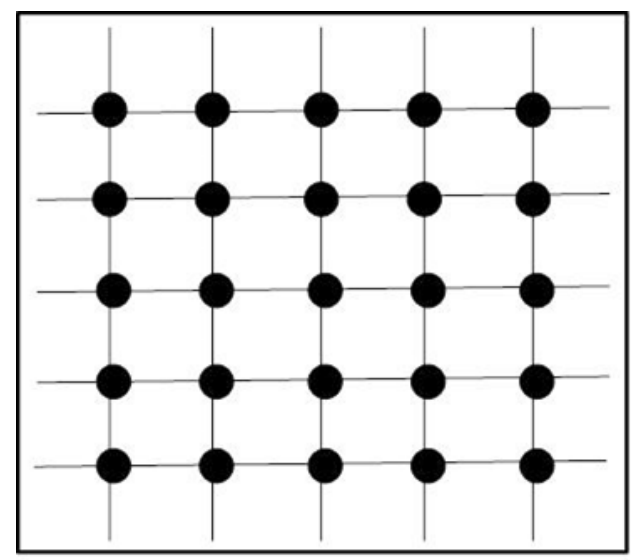

Figura 2.2.2 Plantio de mamão em alinhamento tipo quadrado

Calcule o perímetro ocupado por 900 plantas (mamoeiros) nesse sistema de plantio.

\section{Resolução:}

$$
29 \times 3=87 .
$$

Como o plantio é realizado em alinhamento tipo quadrado, obtemos:

$$
87+87+87+87=328
$$

Portanto, 900 mamoeiros plantados com espaçamento 3 x $3 \mathrm{~m}$ em alinhamento tipo quadrado ocupam um perímetro de $328 \mathrm{~m}$.

\subsubsection{Perímetro de uma circunferência}

O perímetro (comprimento) $\mathrm{C}$ de uma circunferência é dado por: 


$$
C=2 \pi r
$$

Sendo $\pi$ um número irracional, tal que

$$
\pi=3 ; 14159265358979323846 \ldots
$$

\section{3 Áreas}

\subsection{1 Área de uma região quadrada}

A área A de uma região quadrada cuja medida do lado mede lé dada por:

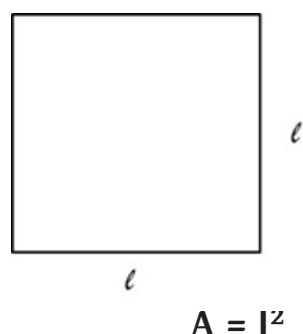

\subsection{2 Área de uma região retangular}

A área A de uma região retangular cujos lados medem a e b é dada por:

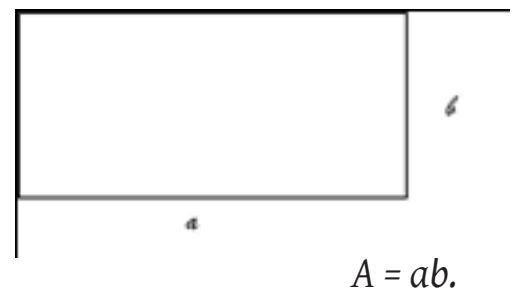

Exemplo 2.3.2.1 Uma instalação necessária à atividade leiteira é a sala de ordenha. Dentre os modelos utilizados, a espinha de peixe se destaca por propiciar bom rendimento, com menor área ocupada, com um dimensionamento de $1,2 \times 1,9 \mathrm{~m}$ por vaca.

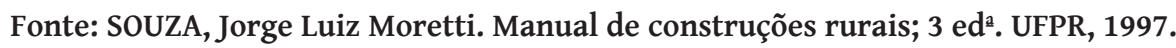

Um produtor de leite pretende construir uma sala de ordenha com capacidade para atender 15 vacas simultaneamente. Qual será a área X, em metros quadrados, destinada para acomodação das vacas durante a ordenha? 
Resolução: Primeiro vamos calcular a área A ocupada por uma vaca.

$$
A=1,2 \times 1,9=2,28 \text {. }
$$

Portanto, cada vaca ocupa um espaço de 2,28 $\mathrm{m}^{2}$. Como o produtor pretende atender 15 vacas, temos:

$$
X=15 \times 2,28=34,2 \text {. }
$$

Logo, a área ocupada pelas 15 vacas durante a ordenha será de 34,2 m².

Exemplo 2.3.2.2 Na instalação de galpões para criação de aves de corte, recomenda-se a construção de galpões retangulares, pois são mais econômicos. 0 galpão pode ser construído de qualquer tamanho, mas, atualmente, por haver a presença de empresas integradoras, é comum a construção de galpões com dimensões 12 x 50 m ou 12 x 100 m. Sendo assim, determine a área superficial ocupada por cada modelo de galpão.

Fonte: SOUZA, Jorge Luiz Moretti. Manual de construções rurais; 3 edª. UFPR, 1997.

Um produtor deseja construir um aviário com capacidade de instalação para 12000 frangos. Sabendo que o produtor irá utilizar altíssima tecnologia de produção.

Informações gerais:

Tabela 2.3.1 Instalações para aves de corte

\begin{tabular}{|c|c|}
\hline Densidade de aves & Características \\
\hline 8 a 12 aves $/ \mathrm{m}^{2}$ & Clima quente e baixa tecnologia \\
\hline 12 a 14 aves $/ \mathrm{m}^{2}$ & Clima frio e alta tecnologia \\
\hline até 18 aves $/ \mathrm{m}^{2}$ & Altíssima tecnologia \\
\hline
\end{tabular}

Responda:

(a) Qual é o número de galpões necessários à produção?

(b) Qual será a área superficial ocupada pelos galpões?

\section{Resolução:}

(a) Como o produtor irá utilizar altíssima tecnologia, pode-se escolher a densidade de até 18 aves/m2. Temos disponíveis dois modelos básicos para galpões:

- Retangular: 12 x 50 m.

- $\quad$ Retangular: 12 x 100 m.

Utilizando a densidade máxima recomendada, obtemos:

$12000: 18=667$. 
Portanto, serão necessários $667 \mathrm{~m} 2$.

Então, para atender a essa necessidade, deve-se construir 2 galpões do tipo 12 x 50 ou 1 galpão do tipo 12 x 100. Entretanto, apesar dessas escolhas corresponderem a uma mesma área superficial ocupada, a escolha por 2 galpões do tipo 12 x 50 implica em um maior perímetro construído, sendo dessa forma menos viável economicamente.

Retangular: 12 x $50 \mathrm{~m}$.

$$
=4 \times 12+4 \times 50=248 .
$$

Retangular: 12 x $100 \mathrm{~m}$.

$$
\mathrm{P}=2 \times 12+2 \times 100=224
$$

Logo, é indicado que o produtor construa 1 galpão do tipo 12 x 100 .

(b) A área superficial ocupada pelos galpões é de $1200 \mathrm{~m}^{2}$, independentemente da escolha por 1 ou 2 galpões.

Exemplo 2.3.2.3 Considere um plantio de mamão no espaçamento $3 \mathrm{~m}$ x $3 \mathrm{~m}$, em um alinhamento tipo quadrado. Calcule a área A ocupada por 1600 mamoeiros nesse tipo de alinhamento.

Resolução: Como são 1600 mamoeiros em alinhamento tipo quadrado, cada lado deve conter 40 mamoeiros.

O comprimento linear $\mathrm{C}$ ocupado por 40 mamoeiros com espaçamento 3 x 3 m é de:

$$
C=(40-1) 3=39 \times 3=117 \text {. }
$$

A área ocupada é dada por:

$$
A=117 \times 117=13689 .
$$

Portanto, a área ocupada é de $13689 \mathrm{~m}^{2}$.

Exemplo 2.3.2.4 Frequentemente, a agricultura tem em si mesma a solução para seus problemas. É o caso da lentilha-d'água, como é conhecida popularmente a lemna, planta aquática que se apresenta como aliada potencial para a sustentabilidade de diferentes atividades agrícolas. De uso diversificado, a cultura em dimensões minúsculas pode ser utilizada para alimentar animais, produzir biocombustível e reduzir impactos da ação de 
poluentes despejados na natureza. Dada a sua elevada capacidade de retirar nutrientes da água, as lemnas têm sido úteis no tratamento de efluentes. Em granjas de suínos, elas são utilizadas na remoção de nitrato e fósforo, componentes dos dejetos de porcos, que são nocivos aos mananciais de águas. Na avaliação de pesquisadores, a cultura é promissora como tecnologia social por sua sustentabilidade, pois despolui a água e, simultaneamente, gera nutrição natural para a engorda de criações. A planta possui um surpreendente teor médio de $35 \%$ de proteína, podendo alcançar picos de $42 \%$.

De acordo com o texto, responda:

Devido à elevada carga proteica, a biomassa de lemna, usada em combinação com outros ingredientes, possibilita reduzir o custo sobre a ração em muitas criações. Pensando nesse benefício, Valdir decidiu construir um tanque retangular com dimensões 20 metros por 10 metros, para cultivar lemnas. Sabendo que a produtividade dessa cultura é de 60 toneladas/ha/ano. Quantas toneladas de lemnas ele espera produzir em 3 anos?

Resolução: Como o tanque é retangular, sua área é dada por:

$$
\mathrm{A}=20 \times 10=200 \mathrm{~m} 2=0,02 \mathrm{ha} \text {. }
$$

Sabendo que essa cultura possui uma produtividade de 60 toneladas/ha/ano, então em 1 ano teremos:

$$
\frac{60}{1}=\frac{X}{0,02} \Rightarrow X=1,2
$$

Dessa forma, em 3 anos, esse produtor espera produzir 3,6 toneladas de lemna em sua propriedade.

\subsection{3 Área de uma região limitada por um paralelogramo}

A área S de uma região limitada por um paralelogramo cuja medida do comprimento da base é b e a medida do comprimento da altura é h é igual à área de uma região retangular cujos comprimentos dos lados medem $b$ e hé dada por $\mathrm{S}=\mathrm{bh}$.
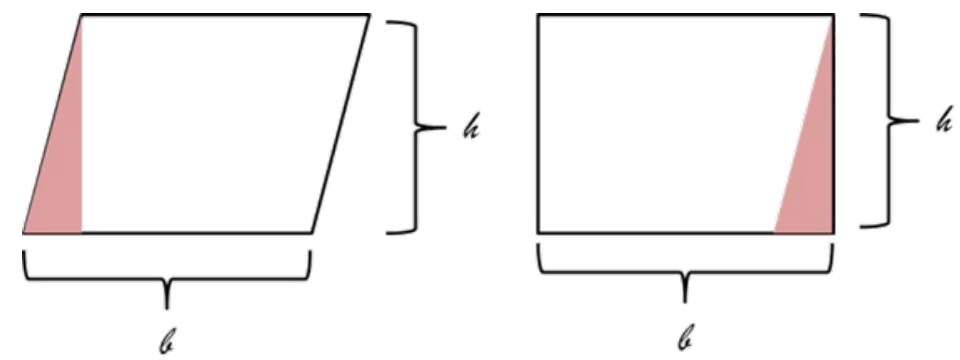

$$
\mathrm{A}=\mathrm{bh} .
$$




\subsection{4 Área de uma região limitada por um triângulo}

Sabemos que a área de um paralelogramo é o produto da medida do comprimento de sua base pela medida do comprimento da altura relativa a essa base.
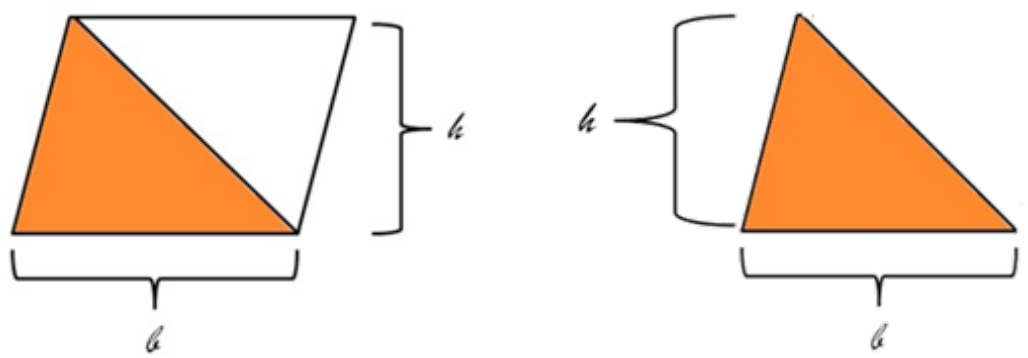

Note que as duas regiões triangulares são congruentes. Logo, essas regiões possuem a mesma área. Dessa forma, temos que a área de uma região triangular é metade da área de um paralelogramo de mesma base e altura. Portanto, a área $\mathrm{S}$ de uma região triangular, cuja medida do comprimento da base mede b e a medida do comprimento da altura relativa à base mede h é dada por:

$$
A=\frac{b h}{2}
$$

Também é possível calcular a área de uma região triangular conhecendo apenas a medida do comprimento de seus lados. Esse método e conhecido como fórmula de Heron. $\mathrm{A}$ área S de um triângulo qualquer de lados a, b e c é dada por:

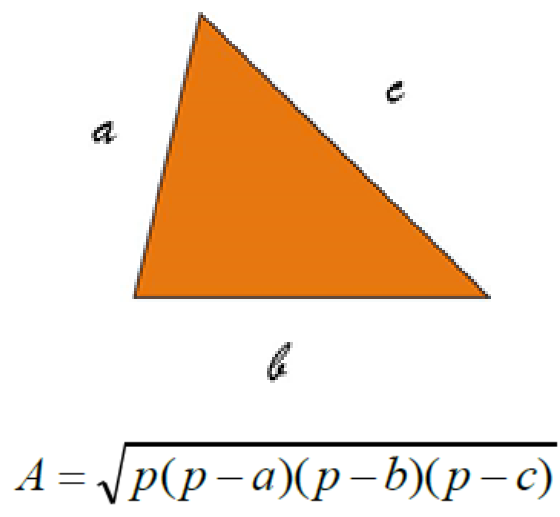

Tal que,

$$
p=\frac{a+b+c}{2} .
$$




\subsection{5 Área de uma região limitada por um trapézio}

Podemos decompor a região limitada pelo trapézio em duas regiões triangulares.

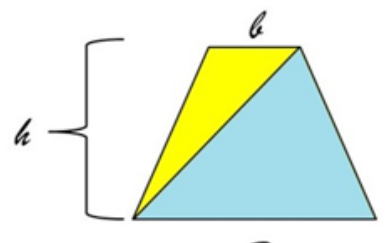

B

Assim temos que a área S de um trapézio é dada pela soma das áreas de duas regiões triangulares

$$
\begin{aligned}
& A=\frac{B h}{2}+\frac{b h}{2} \\
& A=\frac{(B+b) h}{2}
\end{aligned}
$$

\subsection{6 Área de uma região limitada por um losango}

$\mathrm{A}$ área $\mathrm{S}$ de um losango é dada pela metade do produto das medidas dos comprimentos de suas diagonais.

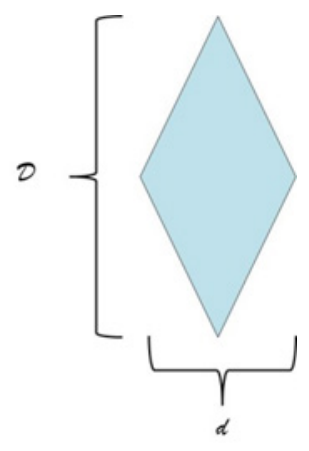

Assim temos:

$$
A=\frac{D d}{2}
$$




\subsection{7 Área de uma região qualquer}

Podemos determinar o valor aproximado da área de uma região não poligonal utilizando uma malha quadriculada.

- Primeiro decalcamos a região sobre uma malha quadriculada;

- Em seguida contamos o número de quadrados inteiros no interior da região;

- Finalmente, contamos o número de quadrados não inteiros no interior da região.

Exemplo 2.3.7.1 Determine o valor aproximado da área limitada por uma região não poligonal a seguir

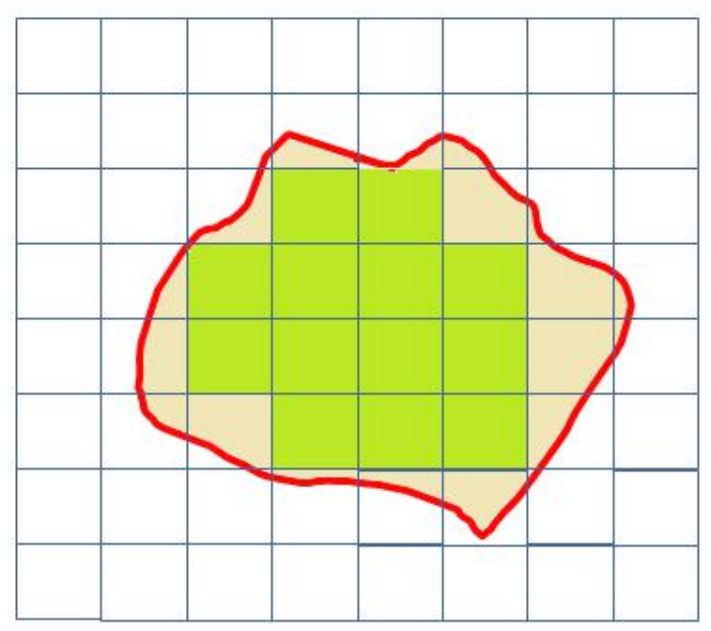

Resolução: $\mathrm{A}$ área $\mathrm{S}$ da região é dada pela média aritmética dos dois valores encontrados.

$$
A=\frac{13+18}{2}=\frac{31}{2}=15,5
$$

Portanto, a área dessa região é 15,5 unidades de área.

\subsection{8 Área de uma região Circular}

A área A de um círculo de raio $\mathrm{r}$ é dada por:

$$
A=\pi r^{2}
$$

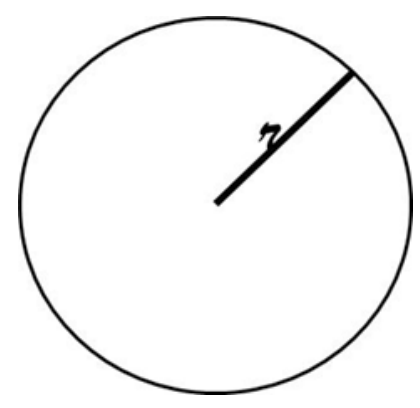


Exemplo 2.3.8.1 Para obter mais qualidade com custo menor, um produtor de café, decidiu instalar em sua propriedade um sistema de secagem natural em terreiro-estufa. Essa técnica otimiza a utilização da energia solar no processo de secagem, produzindo um café de melhor qualidade. Para adequar a sua produção, ele decidiu construir 3 unidades, em formato circular com 8 metros de diâmetro. Qual será a área superficial S ocupada pelas estufas?

Resolução: Primeiro vamos calcular a área S ocupada por uma estufa.

$$
A=\pi 4^{2}=16 \pi
$$

Usando $\pi=3,14$,obtemos:

$$
A=16 .(3,14)=50,24
$$

Portanto, a área ocupada pelas 3 estufas é dada por:

$$
S=3 \times 50,24=150,72 \text {. }
$$

Então, a área ocupada pelas 3 estufas será de 150,72m².

\subsection{Volumes}

\subsubsection{Volume de um cubo}

A medida $\mathrm{V}$ do volume de um cubo de aresta medindo $1 \mathrm{~cm}$ é igual a $1 \mathrm{~cm}^{3}$.

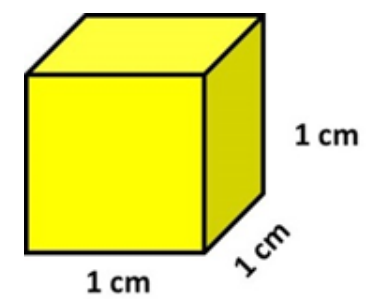

$$
\mathrm{V}=1 \mathrm{x} 1 \mathrm{x} 1=1 \mathrm{~cm} 3
$$

De modo geral, a medida V do volume de um cubo de aresta a é dada por:

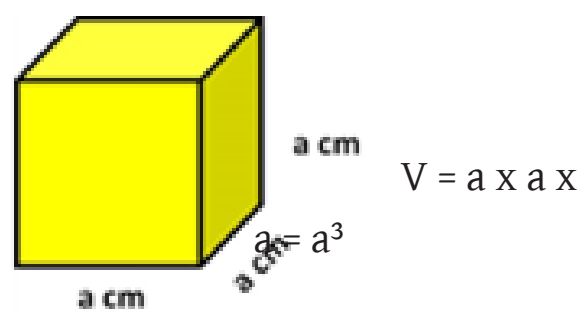




\subsubsection{Volume de um bloco retangular}

A medida $\mathrm{V}$ do volume de um bloco retangular de dimensões a $\mathrm{b}$ c, é dada por:

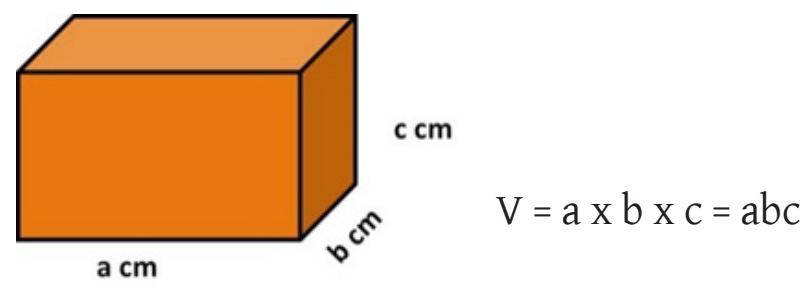

Exemplo 2.4.2.1 Uma propriedade rural possui uma cisterna no formato de um bloco retangular com dimensões 3,2 x 1,5 m. Responda:

(a) Qual é a medida do volume $\mathrm{V}$ dessa cisterna $\mathrm{em}^{3}$.

(b) Qual é a capacidade $\mathrm{C}$ dessa cisterna em litros.

\section{Resolução:}

(a) Como a cisterna possui o formato retangular, seu volume é dado por:

$$
\mathrm{V}=3,2 \times 1,5=9 .
$$

Portanto, a medida do volume da cisterna é de $9 \mathrm{~m}^{3}$.

(b) Como $1 \mathrm{~m}^{3}$ corresponde a 10001 temos:

$$
C=9 \times 1000=9000
$$

Logo, a cisterna possui 9000 litros de capacidade.

Exemplo 2.4.2.2 $\mathrm{O}$ conceito de volume de um bloco retangular é muito importante para determinar o volume de água a ser reposta por um sistema de irrigação. Considere o cultivo de mamão no sistema irrigado. A quantidade de água reposta é determinada pela evapotranspiração do dia anterior. Suponha que no dia anterior houve uma evapotranspiração de 5,0 mm, e as dimensões do plantio são de 12 metros de comprimento por 8 metros de largura. Qual é a quantidade de água, em litros, a ser reposta?

Resolução: Primeiro vamos transformar a medida de precipitação de mil metros para metros.

$$
4: 1000=0,004 \text {. }
$$

Em seguida, vamos determinar o volume total $\mathrm{V}$ de água perdida pela evapotranspiração. 


$$
\mathrm{V}=0,004 \mathrm{~m} \times 12 \mathrm{~m} \times 8 \mathrm{~m}=0,384 \mathrm{~m} 3
$$

Como 1 litro $=1 \mathrm{~m}^{3}$, será necessária a reposição de 384 litros.

\subsection{Volume de um prisma reto qualquer}

Prisma reto é todo sólido geométrico que possui duas bases poligonais paralelas, de mesma forma e tamanho, e possui as faces laterais retangulares.

A medida do volume $\mathrm{V}$ de um prisma reto qualquer é dada pelo produto da área da base B pela altura h.

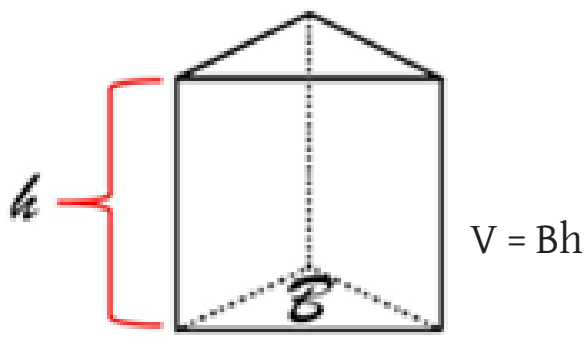

Exemplo 2.5.1 O silo trincheira é indicado para silagem de plantas e grãos. A instalação desse tipo de silo possui como pontos favoráveis a facilidade de enchimento e propicia menores perdas. Como desvantagens, ele exige custos com a construção e um local com declividade adequada.

Observe a figura a seguir, onde está representado um silo trincheira (trapezoidal).

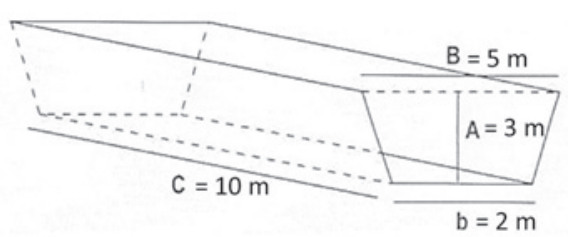

Figura 2.5.1 Silo trincheira

Note que este silo possui o formato de um prisma reto, tendo como base um trapézio isósceles. Sabendo que a densidade da silagem de milho é de $600 \mathrm{~kg} / \mathrm{m}^{3}$. Responda:

(a) Qual é a medida do volume desse silo, em metros cúbicos?

(b) Qual é a quantidade total de armazenagem, em quilogramas, desse silo? 


\section{Resolução:}

(a) Primeiro vamos calcular a área B da base do silo. Como a base desse silo é trapezoidal, segue que:

$$
B=\frac{(5+2) 3}{2}=\frac{21}{2}=10,5
$$

Logo, a área da base é $10,5 \mathrm{~m}^{2}$.

Agora vamos calcular o volume $\mathrm{V}$ do silo.

$$
\mathrm{V}=10,5 \times 10=105 .
$$

Portanto, o silo possui volume igual a $105 \mathrm{~m}^{3}$.

(b) A quantidade $Q$ de silagem é dada por:

$$
\mathrm{Q}=600 \mathrm{~V}=600 \times 105=63000
$$

Portanto, esse silo possui potencial de armazenamento de $63000 \mathrm{~kg}$ de silagem de milho, ou 63 toneladas.

\subsection{Volume de um cilindro reto}

Cilindro reto é todo sólido geométrico que possui duas bases circulares paralelas, de mesma forma e tamanho, e possui a face lateral arredondada. A medida do volume $\mathrm{V}$ de um cilindro reto qualquer é dado pelo produto da área da base B pela altura h.]

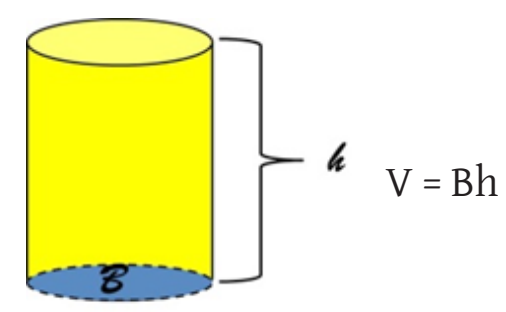

Exemplo 2.6.1 A figura a seguir representa uma cisterna cilíndrica cujas medidas de profundidade $\mathrm{H}$, diâmetro $\mathrm{D}$ e altura da coluna de água $\mathrm{h}_{2}$, estão indicadas: 


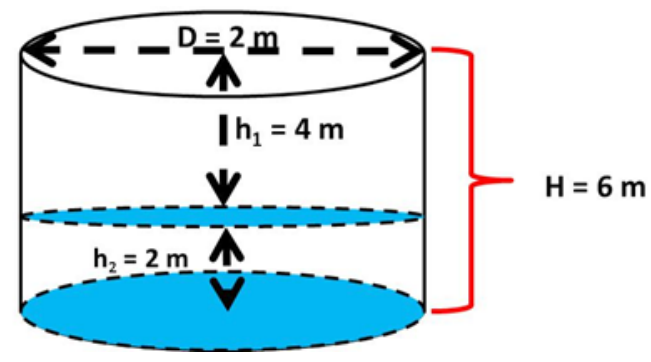

Responda:

(a) Qual é a medida do raio $r$ da cisterna?

(b) Qual é a medida do volume total V da cisterna, em metros cúbicos?

(c) Qual é a medida do volume da coluna de água $\mathrm{V}_{\mathrm{A}}$ da cisterna, em metros cúbicos?

(d) Qual é a capacidade total C da cisterna, em litros?

\section{Resolução:}

(a) A medida do raio $r$ da base da cisterna é a metade da medida de seu diâmetro.

$$
r=\frac{D}{2}=\frac{2}{2}=1
$$

(b) Como a cisterna é em forma de cilindro, a medida de seu volume V é dada por:

$$
V=\pi r^{2} h=3,14 \cdot 1^{2} \cdot 6=18,84
$$

Portanto, o volume total dessa cisterna é de $18,84 \mathrm{~m}^{3}$.

(c) Como a coluna de água da cisterna tem $2 \mathrm{~m}$ de altura, a medida de seu volume $\mathrm{V}_{\mathrm{A}}$ é dada por:

$$
V_{A}=\pi 1^{2} \cdot 2=3,14 \cdot 2=6,28
$$

Portanto, o volume da coluna de água é de $2 \mathrm{~m}^{3}$.

(d) Usando $\pi=3,14$. Temos que a capacidade total $C$ da cisterna, em litros é:

$$
C=18,84 \times 1000 \times 18840
$$

Logo, a capacidade total da cisterna é de 18840 litros.

Exemplo 2.6.2 A Empresa de Assistência Rural de Minas Gerais (Emater-MG) está 
aconselhando, principalmente aos pequenos produtores, o uso do silo cincho para armazenar o capim-elefante, que é bastante usado na alimentação do gado. 0 cincho é um modelo de superfície e possui menos capacidade de armazenamento inferior a 10 toneladas de silagem, o que o torna mais útil aos pequenos pecuaristas, cujo rebanho possui menor número de cabeças. A construção do silo pode ser feita com uma chapa de aço galvanizado, com $60 \mathrm{~cm}$ de largura e comprimento variável, dependendo do volume a ser armazenado. A chapa é amarrada com arame em suas extremidades, formando um anel. Em seguida ela é fixada ao solo com cinco estacas, evitando que se desloque a compactação inicial da silagem. Usando uma chapa de 12 metros de comprimento na construção de um silo cincho. Responda:

Considerando que, após a silagem, 1 tonelada de forragem ocupa $2 \mathrm{~m}^{3}$ desse tipo de silo. Calcule a capacidade total de armazenamento, em toneladas, desse silo.

Resolução: Inicialmente, vamos determinar a medida do comprimento do raio da base desse silo. Usando $\pi=3$, obtemos:

$$
C=2 \cdot \pi \cdot r \Rightarrow 12=2 \cdot 3 \cdot r \Rightarrow 12=6 r \Rightarrow r=2 .
$$

Como a chapa possui 0,60 $\mathrm{m}$ de largura, essa será também a medida do comprimento da altura desse silo. Desse modo, obtemos:

$$
V=\pi \cdot r^{2} \cdot h=3 \cdot 2^{2} \cdot 0,60=7,2
$$

Como 1 tonelada de forragem ocupa $2 \mathrm{~m}^{3}$, a capacidade total de armazenamento desse silo cincho é de 3,6 toneladas.

Exemplo 2.6.3 Valdir é um suinocultor e deseja construir um biodigestor em sua propriedade para utilizar a lemna no tratamento dos dejetos de sua produção. Para isso, ele escolheu o formato cilíndrico para seu biodigestor, com 5 metros de diâmetro e 3,2 de altura. Dessa forma, calcule o volume máximo de armazenamento de dejetos desse biodigestor. (Use $\pi=3$ ).

Resolução: Como o biodigestor possui 5 metros de diâmetro, a medida do raio será de 2,5 metros. Dessa forma, seu volume é dado por:

$$
V=\pi \cdot r^{2} \cdot h=3 \cdot 2,5^{2} \cdot 3,2=60 .
$$

Logo, o volume total do biodigestor é de $60 \mathrm{~m}^{3}$. 


\subsection{Volume de um cone}

A medida $\mathrm{V}$ do volume de um cone é igual a um terço do volume de um cilindro de mesma área da base e mesma altura.

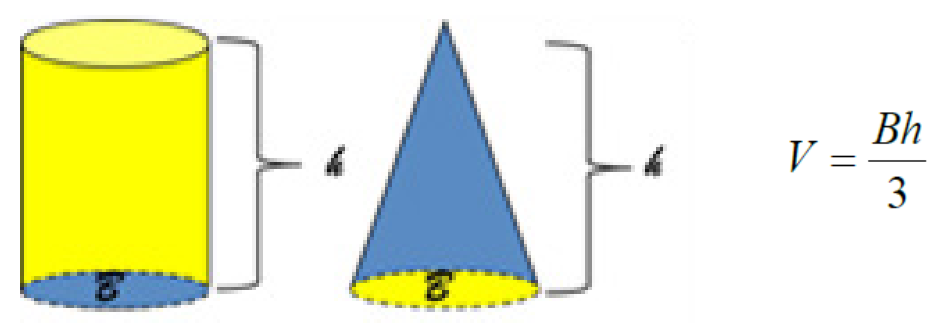

Exemplo 2.7.1 Para que não haja desperdício de ração e que seus animais estejam sempre bem nutridos, um produtor construiu um comedouro com uma pequena abertura na parte inferior, que permite a reposição automática da ração, conforme mostra a figura a seguir:

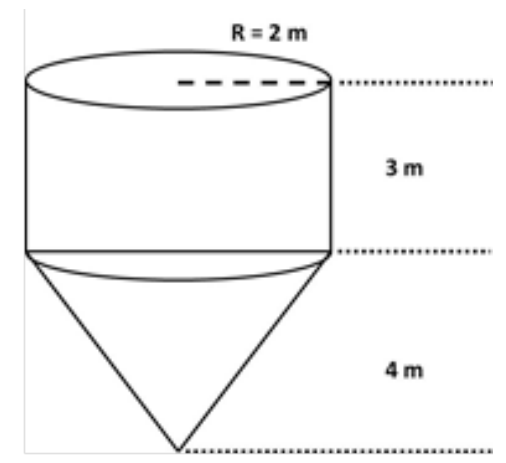

Dessa forma, calcule o volume máximo de armazenamento desse comedouro.

Resolução: Inicialmente, vamos calcular o volume do cilindro.

$$
\mathrm{V}_{\text {cilindro }}=2^{2} \cdot 3 \cdot 3=36
$$

Agora vamos determinar o volume do cone.

$$
V_{\text {cone }}=\frac{3 \cdot 2^{2} \cdot 4}{3}=\frac{48}{3}=16
$$

Portanto, o comedouro possui um volume total dado por:

$$
V_{\text {total }}=16+36=52 \mathrm{~m}^{3}
$$




\subsection{Volume de uma pirâmide}

A medida $\mathrm{V}$ do volume de uma pirâmide é igual a um terço do volume de um prisma de mesma área da base e mesma altura.

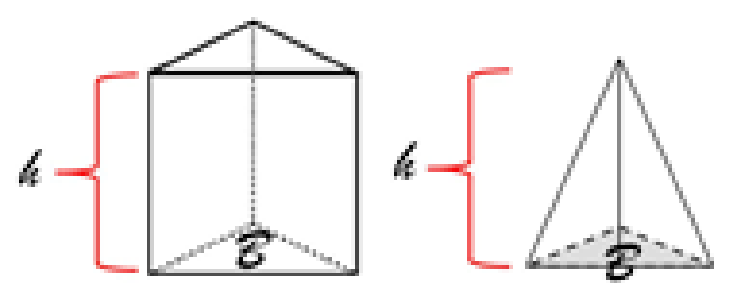

\subsection{Volume de uma esfera}

A medida $\mathrm{V}$ do volume de uma esfera de raio $\mathrm{r}$ é dada por:

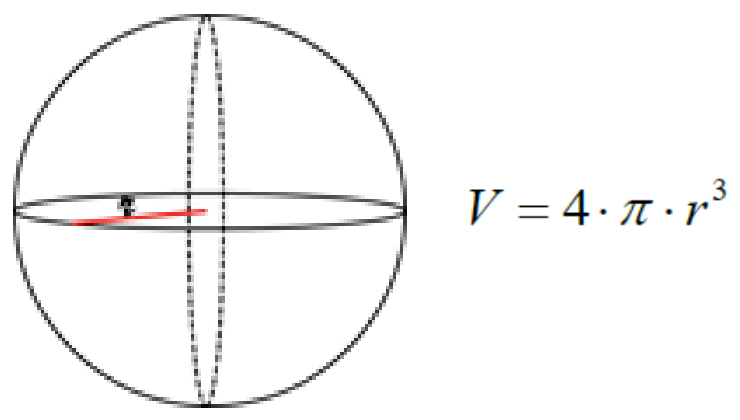

\subsection{Problemas - Capítulo 2}

Problema 2.10.1 Escreva a expressão para determinar o perímetro em função das medidas dos lados de cada figura plana abaixo.
(a) Paralelogramo.
(b) Losango.
(c) Triângulo equilátero.
(d) Hexágono regular.

Problema 2.10.2 A figura abaixo representa um croqui localizando um plantio de café no espaçamento 3,2m x 1m, num alinhamento tipo retangular. 


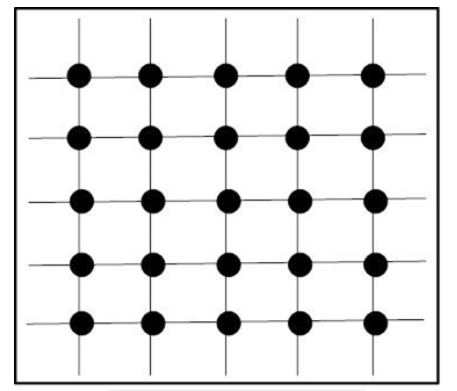

Calcule o perímetro ocupado por 12.000 plantas nesse sistema de plantio.

Problema 2.10.3 Responda:

(a) Triplicando a medida do raio de uma circunferência, qual efeito ocorre na medida de seu comprimento?

(b) Dividindo a medida do raio de uma circunferência por 3, qual efeito ocorre na medida de seu comprimento?

(c) A medida do comprimento de uma circunferência está em correspondência com a medida do seu raio? Essa correspondência obedece a uma proporção?

Problema 2.10.4 Considere um quadrado de $80 \mathrm{~cm}$ de perímetro. Determine o comprimento da circunferência inscrita nesse quadrado.

Problema 2.10.5 Considere uma circunferência de raio $\mathrm{r} \mathrm{cm}$. Explique o que ocorre com a medida do comprimento dessa circunferência:

(a) se aumentarmos a medida do raio em $1 \mathrm{~cm}$.

(b) se aumentarmos a medida do raio em $2 \mathrm{~cm}$.

Problema 2.10.6 Considere uma circunferência de $8 \mathrm{~cm}$ de raio. Calcule:

(a) A medida do comprimento dessa circunferência.

(b) A medida do comprimento do arco de circunferência determinado pelo ângulo central de 450 .

Problema 2.10.7 A área de um sítio retangular é de $600000 \mathrm{~m} 2.0$ comprimento desse sítio é de 200 metros. Quanto mede a largura desse sítio?

Problema 2.10.8 Escreva a expressão para determinar a área em função das medidas de cada figura plana abaixo.

(a) Trapézio isósceles tal que a medida do comprimento da base maior é o dobro da medida do comprimento da base menor e possui altura h. 
(b) Losango.

(c) Triângulo isósceles tal que a medida do comprimento da base é o dobro da medida do comprimento dos lados iguais e possui altura $h$.

(d) Hexágono regular.

Problema 2.10.9 Encontre a expressão que determina a área de um triângulo equilátero em termos de sua altura.

Problema 2.10.10 Considere um plantio de milho no espaçamento $1 \mathrm{~m}$ x 0,20m, em um alinhamento tipo retangular. Calcule a área A ocupada por 80000 plantas nesse tipo de alinhamento.

Problema 2.10.11 Considere uma região circular de raio $\mathrm{r}$ metros. Explique o que ocorre com o valor da área dessa região:

(a) se aumentarmos a medida do comprimento do raio em 1 metro.

(b) se aumentarmos a medida do comprimento do raio em 2 metros.

(c) se dobrarmos a medida do comprimento do raio.

(d) se triplicarmos a medida do comprimento do raio.

(e) se dividirmos pela metade o comprimento do raio.

Problema 2.10.12 Um produtor deseja construir um aviário com capacidade de instalação para 24.000 frangos. Sabendo que o produtor irá utilizar baixa tecnologia de produção em uma região de clima quente, observada a tabela a seguir:

Tabela 2.10.1 - Instalações par aves de corte

\begin{tabular}{|c|c|}
\hline Densidade de aves & Características \\
\hline 8 a 12 aves $/ \mathrm{m}^{2}$ & Clima quente e baixa tecnologia \\
\hline 12 a 14 aves $/ \mathrm{m}^{2}$ & Clima frio e alta tecnologia \\
\hline até 18 aves $/ \mathrm{m}^{2}$ & Altíssima tecnologia \\
\hline
\end{tabular}

Responda:

(a) Qual é o número de galpões necessários à produção?

(b) Qual será a área superficial ocupada pelos galpões?

Problema 2.10.13 Um produtor de leite pretende construir uma sala de ordenha, no modelo espinha de peixe, com capacidade para atender 40 vacas simultaneamente. Qual será a área X, em metros quadrados, destinada para acomodação das vacas durante a ordenha? 
Problema 2.10.14 Considere um plantio de café no espaçamento $3,2 \mathrm{~m} \times 1 \mathrm{~m}$, em um alinhamento tipo retangular. Calcule a área A ocupada por 12000 plantas nesse tipo de alinhamento.

Problema 2.10.15 A figura abaixo representa quatro circunferências iguais, de raio 5 $\mathrm{cm}$, tangentes entre si, e tangentes ao quadrado. Calcule a área da região colorida.

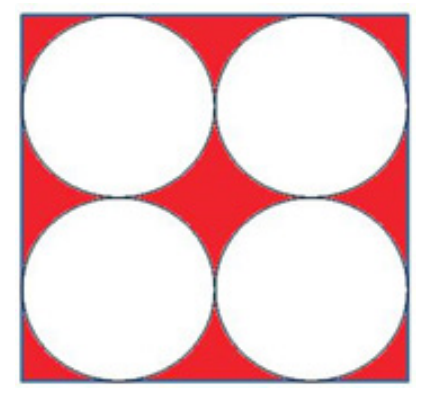

Problema 2.10.16 Considere um plantio de citros no espaçamento $4 \mathrm{~m}$ x 5m, em um alinhamento tipo retangular. Calcule a área A ocupada por 4800 plantas nesse tipo de alinhamento.

Problema 2.10.17 Um produtor rural deseja construir um depósito de agrotóxicos em sua propriedade. Para isso, ele usar um espaço trapezoidal, de modo que, a base maior e a base menor, medem respectivamente, $6 \mathrm{~m}$ e $4 \mathrm{~m}$ e a distância (altura) entre as bases e $3 \mathrm{~m}$. Calcule a área superficial desse depósito.

Problema 2.10.18 Determine o valor aproximado da área não poligonal representada sobre a malha quadriculada abaixo.

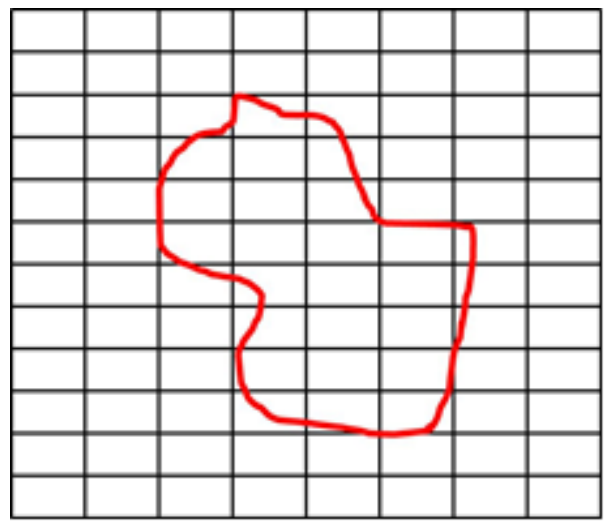

Problema 2.10.19 o Teorema de Pitágoras é o mais famoso teorema da Matemática. Entretanto, o que pouca gente sabe é, que o teorema de Pitágoras é essencialmente um teorema sobre áreas de figuras semelhantes. Seu enunciado esconde uma relação mais geral. 0 verdadeiro enunciado do Teorema de Pitágoras diz: 
"Em um triângulo retângulo, a área da figura construída sobre a hipotenusa é igual à soma das áreas de figura semelhantes construídas sobre os catetos."

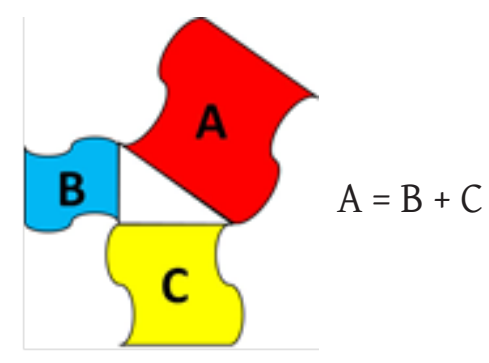

Então, quando dizemos que em um triângulo retângulo de hipotenusa a e catetos b e c que:

$$
\mathrm{a}^{2}=\mathrm{b}^{2}+\mathrm{c}^{2}
$$

Estamos nos referindo ao caso particular em que as figuras construídas sobre os lados do triângulo retângulo são, em especial, quadrados.

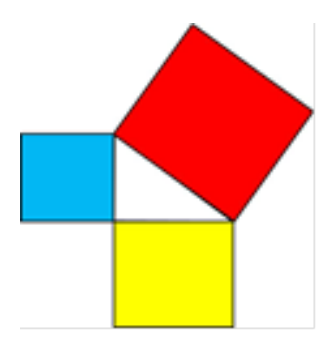

Sendo assim, determine a área do semicírculo construído sobre um triângulo retângulo de diâmetro igual à hipotenusa, cujos catetos medem 3 e 4.

Problema 2.10.20 A figura a seguir representa um silo cilíndrico tipo cisterna.

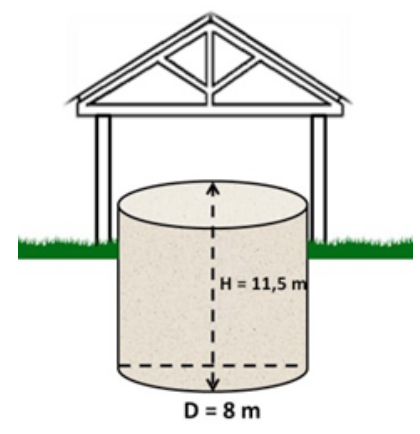

Responda:

(a) Qual é a medida do raio desse silo?

(b) Qual é a medida do volume total V, em metros cúbicos?

(c) Qual é, em toneladas, a massa total de silagem que pode ser armazenada no 
silo, sabendo-se que a relação entre a massa de silagem, por unidade de volume (massa específica de silagem), é e $=500 \mathrm{~kg} / \mathrm{m}^{3}$ ?

(d) Qual é, em toneladas, a massa de silagem quando o silo estiver cheio até a altura $\mathrm{h}=1,2 \mathrm{~m}$, sendo e $=500 \mathrm{~kg} / \mathrm{m} 3$ ?

(e) Qual é, em toneladas, a massa de silagem quando o silo estiver cheio até a altura $\mathrm{h}=5 \mathrm{~m}$, sendo $\mathrm{e}=500 \mathrm{~kg} / \mathrm{m} 3$ ?

Problema 2.10.21 Observe a figura abaixo, onde está representado um silo trincheira.

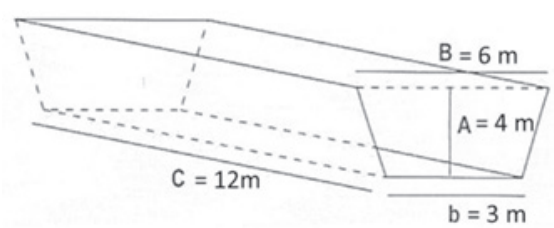

Sabendo que a densidade da silagem de milho é de $600 \mathrm{~kg} / \mathrm{m}^{3}$. Responda:

(a) Qual é a medida do volume desse silo, em metros cúbicos?

(b) Qual é a quantidade total de armazenagem, em toneladas, desse silo?

Problema 2.10.22 Um tanque subterrâneo tem a forma de um cone reto invertido com 18 metros de profundidade. Este tanque está completamente cheio com 64000 litros de água. Calcule a medida do diâmetro da base desse tanque.

Problema 2.10.23 A figura abaixo representa um silo para o armazenamento de grãos. Calcule o volume total de armazenamento desse silo.

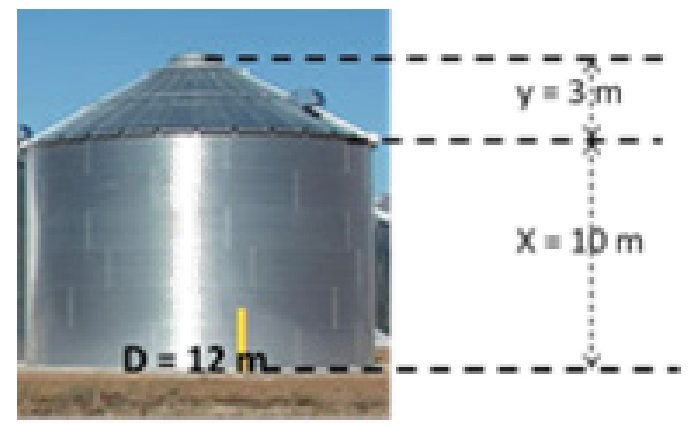

Problema 2.10.24 Um reservatório tem a forma de um bloco retangular, com 10m de comprimento, $6 \mathrm{~m}$ de largura e $2,5 \mathrm{~m}$ de profundidade.

(a) Calcule seu volume em litros.

(b) Determine quantos ladrilhos quadrados de $20 \mathrm{~cm}$ de lado são necessários 
para ladrilhar todo o reservatório.

Problema 2.10.25 Silos semiesféricos são grandes depósitos horizontais. A figura abaixo representa um silo semiesférico com 20 metros de diâmetro.

Determine o volume, em metros cúbicos, desse silo.

Problema 2.10.26 Se você fosse consultado sobre a necessidade de instalação de um tanque de dimensões: $8 \mathrm{~m}$ de comprimento, $6 \mathrm{~m}$ de largura e $1,8 \mathrm{~m}$ de profundidade, para a criação de tilápia, em uma propriedade rural. Qual seria a capacidade, em litros de água, para encher o tanque?

Problema 2.10.27 Suponha que, para a alimentação de 40 vacas, por um período de 120 dias, sejam necessárias 120 toneladas de forragem, cuja densidade é de $600 \mathrm{~kg} / \mathrm{m}^{3}$. Nessa situação, um silo cilíndrico com $12 \mathrm{~m}$ de altura e $3 \mathrm{~m}$ de diâmetro seria suficiente para armazenar essa quantidade de forragem?

Problema 2.10.28 Considere o cultivo de mamão no sistema irrigado. A quantidade de água reposta é determinada pela evapotranspiração do dia anterior. Suponha que no dia anterior houve uma evapotranspiração de $5 \mathrm{~mm}$, e as dimensões do plantio são de 12 metros de comprimento por 8 metros de largura. Qual é a quantidade de água, em litros, a ser reposta?

Problema 2.10.29 Para reparos na rede de drenagem das águas pluviais, a prefeitura trocou uma manilha de água cilíndrica de 9 metros de comprimento e 4 metros de diâmetro por duas manilhas cilíndricas de 9 metros de comprimento e 2 metros de diâmetro. A troca feita pela Secretaria de Obras foi correta? Justifique sua resposta com cálculos.

Problema 2.10.30 Usando uma chapa de 15 metros de comprimento e 80 centímetros de largura na construção de um silo cincho. Responda os itens a seguir:

(a) Sabendo que a chapa custa $\mathrm{R} \$ 29,50$ o metro quadrado, calcule o valor, em reais, dessa chapa.

(b) Considerando que, após a silagem, 1 tonelada de forragem ocupa 1,5m3 desse tipo de silo. Calcule a capacidade total de armazenamento, em toneladas, desse silo. 


\section{Trigonometria Aplicada}

\subsection{Noções Preliminares}

A palavra Trigonometria tem origem do grego trigonon, que significa triângulo, e metria, que significa medida. Dessa forma, a trigonometria é um ramo da matemática dedicada ao cálculo de medidas de triângulos. Uma notável aplicação da trigonometria é medir distâncias inacessíveis, tais como: o comprimento da largura de um rio, a medida da altura de uma montanha, a altura de um edifício. Vamos iniciar o estudo da trigonometria por meio da análise das relações entre as medidas de triângulos retângulos.

\subsection{Razões Trigonométricas: Seno, Cosseno e Tangente}

Chamamos de seno do ângulo A a razão entre a medida do comprimento do cateto oposto ao ângulo e a medida do comprimento da hipotenusa.

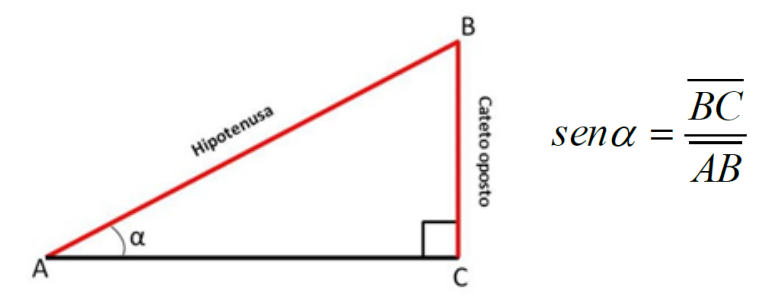

A razão entre a medida do comprimento do cateto adjacente ao ângulo e a medida do comprimento da hipotenusa denomina-se cosseno do ângulo.

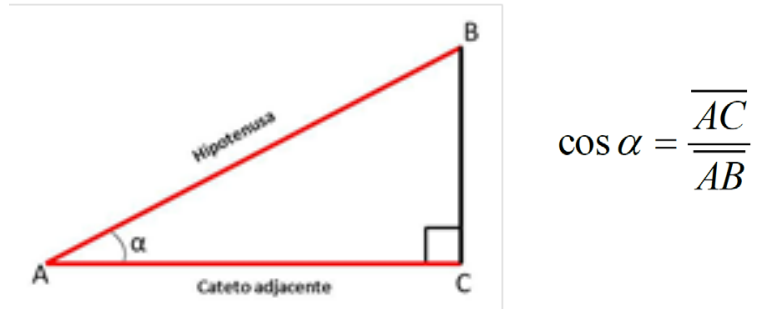

Quando temos dois ângulos tais que $\alpha+\beta=90^{\circ}$, então:

$$
\begin{aligned}
& \operatorname{sen} \alpha=\cos \beta \\
& \operatorname{sen} \beta=\cos \alpha
\end{aligned}
$$

De fato, o nome cosseno significa seno do ângulo complementar.

A razão entre a medida do comprimento do cateto oposto ao ângulo e a medida do comprimento do cateto adjacente denomina-se tangente do ângulo. 


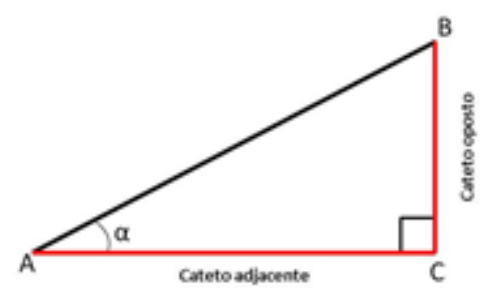

$$
\operatorname{ta} \alpha=\frac{\overline{B C}}{\overline{A C}}
$$

A tangente de um ângulo também é determinada pela razão entre o valor do seno e do cosseno do ângulo.

$$
\operatorname{ta} \alpha=\frac{\operatorname{sen} \alpha}{\cos \alpha}
$$

Exemplo 3.2.1 Observe o triângulo retângulo a seguir.

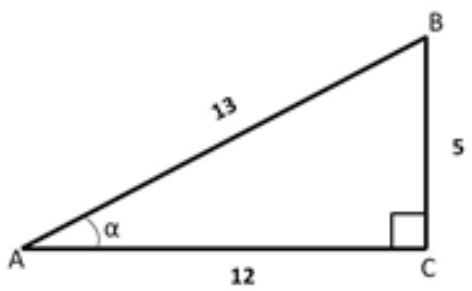

Determine o valor do seno, cosseno e tangente do ângulo.

Resolução: Para determinamos o valor do sen $\alpha$ são necessárias as medidas do comprimento do cateto oposto ao ângulo e do comprimento da hipotenusa. Dessa forma, obtemos:

$$
\operatorname{sen} \alpha=\frac{5}{13}
$$

Para obtermos o $\cos \alpha$ são necessárias as medidas do cateto adjacente ao ângulo e do comprimento da hipotenusa.

$$
\cos \alpha=\frac{12}{13}
$$

Por fim, para determinarmos o valor da tg $\alpha$ são necessárias as medidas dos comprimentos dos catetos.

$$
\operatorname{tg} \alpha=\frac{5}{12}
$$




\subsection{Razões trigonométricas do ângulo de $45^{\circ}$}

Observe o quadrado $\mathrm{ABCD}$ tal que a medida do comprimento do lado é a.

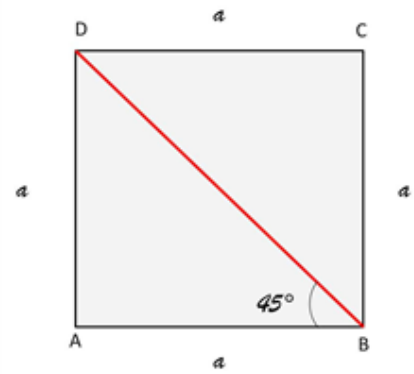

Note que o ângulo de $45^{\circ}$ forma-se espontaneamente pela diagonal do quadrado e o seu lado. Por essa razão, chamamos o ângulo de 450 de ângulo notável. Aplicando o Teorema de Pitágoras, obtemos a medida do comprimento da diagonal.

$$
\begin{aligned}
& d^{2}=a^{2}+a^{2} \\
& d^{2}=2 a^{2} \\
& d=\sqrt{2 a^{2}} \\
& d=a \sqrt{2}
\end{aligned}
$$

Desse modo, segue que:

$$
\begin{aligned}
& \operatorname{sen} 45^{\circ}=\frac{a}{a \sqrt{2}}=\frac{1}{\sqrt{2}}=\frac{\sqrt{2}}{2} \\
& \cos 45^{\circ}=\frac{a}{a \sqrt{2}}=\frac{1}{\sqrt{2}}=\frac{\sqrt{2}}{2} \\
& \operatorname{tg} 45^{\circ}=\frac{a}{a}=1
\end{aligned}
$$

\subsection{Razões trigonométricas dos ângulos $30^{\circ} \mathrm{e} 60^{\circ}$}

Observe o triângulo equilátero $\mathrm{ABC}$ cuja medida do comprimento do lado é a. 


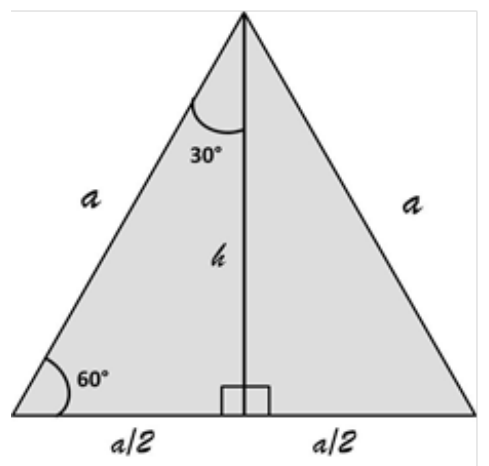

Dessa forma, sabemos que os ângulos internos do triângulo $A B C$ são todos iguais e medem $60^{\circ}$. Podemos observar também que o ângulo de $30^{\circ}$ surge espontaneamente traçando a altura desse triângulo equilátero. Dessa forma, os ângulos de $30^{\circ}$ e $60^{\circ}$ são chamados de ângulos notáveis.

Vamos inicialmente determinar a medida do comprimento da altura h desse triângulo. Aplicando o Teorema de Pitágoras, obtemos:

$$
\begin{aligned}
& a^{2}=h^{2}+\left(\frac{a}{2}\right) \\
& a^{2}=h^{2}+\frac{a^{2}}{4} \\
& 4 a^{2}=4 h^{2}+a^{2} \\
& 3 a^{2}=4 h^{2} \\
& h^{2}=\frac{3 a^{2}}{4} \\
& h=\sqrt{\frac{3 a^{2}}{4}} \\
& h=\frac{a \sqrt{3}}{2}
\end{aligned}
$$

Então, podemos agora calcular as razões trigonométricas. Para o ângulo de $30^{\circ}$, temos:

$$
\begin{aligned}
& \operatorname{sen} 30^{\circ}=\frac{a / 2}{a}=\frac{a}{2 a}=\frac{1}{2} \\
& \cos 30^{\circ}=\frac{a \sqrt{3} / 2}{a}=\frac{a \sqrt{3}}{2 a}=\frac{\sqrt{3}}{2} \\
& \operatorname{tg} 30^{\circ}=\frac{a / 2}{a \sqrt{3} / 2}=\frac{1}{\sqrt{3}}=\frac{\sqrt{3}}{3}
\end{aligned}
$$


Para o ângulo de 60ㅜㄴ, temos:

$$
\begin{aligned}
& \operatorname{sen} 60^{\circ}=\frac{a \sqrt{3} / 2}{a}=\frac{a \sqrt{3}}{2 a}=\frac{\sqrt{3}}{2} \\
& \cos 60^{\circ}=\frac{a / 2}{a}=\frac{a}{2 a}=\frac{1}{2} \\
& \operatorname{tg} 60^{\circ}=\frac{a \sqrt{3} / 2}{a / 2}=\sqrt{3}
\end{aligned}
$$

Esses valores podem ser resumidos na tabela a seguir:

\begin{tabular}{|l|c|c|c|}
\hline & Seno & Cosseno & Tangente \\
\hline $30^{\circ}$ & $1 / 2$ & $\sqrt{3} / 2$ & $\sqrt{3} / 3$ \\
\hline $45^{\circ}$ & $\sqrt{2} / 2$ & $\sqrt{2} / 2$ & 1 \\
\hline $60^{\circ}$ & $\sqrt{3} / 2$ & $1 / 2$ & $\sqrt{3}$ \\
\hline
\end{tabular}

Exemplo 3.4.1 Uma pessoa encontra-se no ponto A, localizado na base do edifício, conforme mostra a figura a seguir.

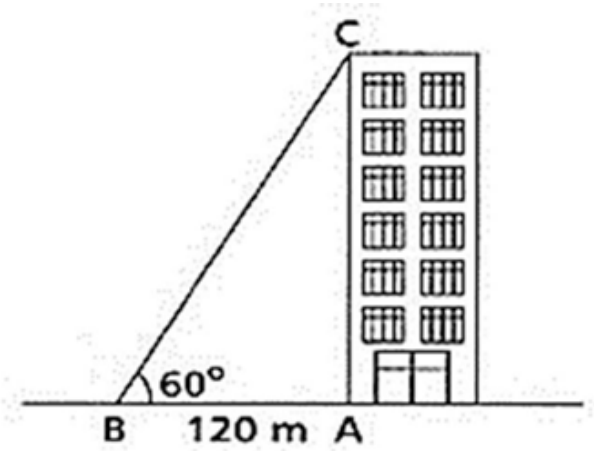

Essa pessoa decidiu caminhar 120 metros em linha reta, se afastando do edifício, até chegar ao ponto B, onde ela pode avistar o topo do edifício sob um ângulo de 600 . Com base nesses dados, determine a altura h desse edifício.

Resolução: Note que, nessa situação, dispomos da medida do cateto adjacente ao ângulo de observação e desejamos calcular a medida do cateto oposto ao ângulo de obser- 
vação. Nesse caso, devemos utilizar como ferramenta a razão da tangente.

$$
\operatorname{tg} 60^{\circ}=\frac{h}{120} \Rightarrow \sqrt{3}=\frac{h}{120} \Rightarrow h=120 \sqrt{3}
$$

Logo, o edifício possui $120 \sqrt{3}$ metros de altura.

Exemplo 3.4.2 Um técnico em agropecuária está fazendo um levantamento topográfico da região onde será realizado um experimento de campo. Ele quer determinar a largura do rio que corta a região, e por isso adotou os seguintes procedimentos: marcou dois pontos, A (uma árvore que ele observou na outra margem) e B (uma estaca que ele fincou no chão na margem onde ele se encontra); marcou um ponto $C$ distante 9 metros de $B$, fixou o teodolito de tal modo que o ângulo no ponto B seja reto e obteve uma medida de $60^{\circ}$ para o ângulo ACB. Qual foi a largura do rio que ele encontrou?

Resolução: De acordo com o texto, obtemos a seguinte figura.

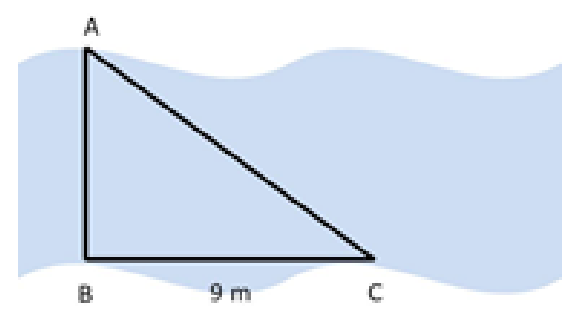

Então, devemos usar a tangente de $60^{\circ}$.

$$
\operatorname{tg} 60^{\circ}=\frac{X}{9} \Rightarrow \sqrt{3}=\frac{X}{9} \Rightarrow X=9 \sqrt{3}
$$

Usando $\sqrt{3}=1,7$ temos que a medida da largura do rio encontrada foi de 15,3 metros.

Exemplo 3.4.3 Em geral, nas construções rurais, os telhados são projetados com um grau mínimo de inclinação, em função do custo. Para as medidas do modelo de telhado representado a seguir, o valor do ângulo agudo é dado por?

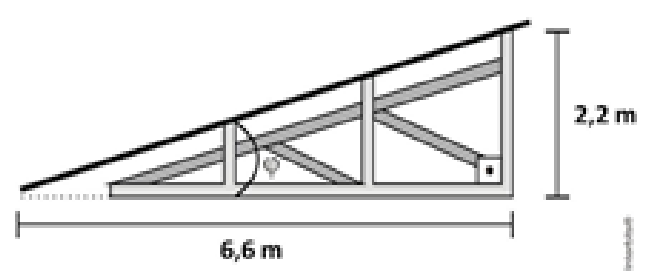

Resolução: Inicialmente, vamos determinar o valor da tangente do ângulo. 


$$
\operatorname{tg} \varphi=\frac{2,2}{6,6}=\frac{1}{3}
$$

Usando uma calculadora científica, encontramos que $\varphi=18^{\circ} 26^{\prime} 05^{\prime \prime}$.

\subsection{Trigonometria em um triângulo qualquer}

\subsubsection{Lei dos Cossenos}

Dado um triângulo qualquer cujos lados medem a, b e c e seja $\alpha$ o ângulo oposto ao lado de medida a.

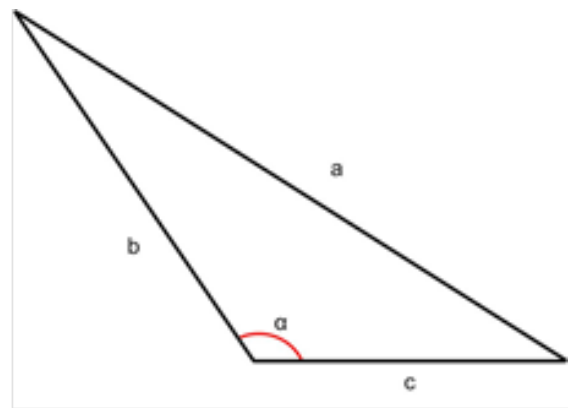

Então,

$$
a^{2}=b^{2}+c^{2}-2 b c \cos \alpha
$$

Problema 3.5.1.1 Em certa propriedade, o galinheiro está no ponto A, a plantação de laranja no ponto B e a plantação de milho encontra-se no ponto C, como mostrado a seguir. Sabendo que a distância do galinheiro à plantação de laranja é de 10 metros, a distância da plantação de laranja à plantação de milho corresponde a 15 metros, e que o ângulo formado por essas direções é de $60^{\circ}$. Qual é a distância do galinheiro à plantação de milho?

Resolução: Representando graficamente os dados do problema, obtemos:

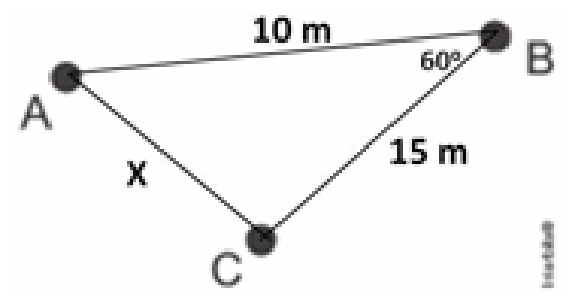


Aplicando a Lei dos Cossenos, temos:

$$
\begin{aligned}
& X^{2}=10^{2}+15^{2}-2 \cdot 10 \cdot 15 \cdot \cos 60^{\circ} \\
& X^{2}=100+225-300 \cdot 0,5 \\
& X^{2}=100+225-150 \\
& X^{2}=175 \\
& X=\sqrt{175} \\
& X=5 \sqrt{7}
\end{aligned}
$$

\subsubsection{Lei dos Senos}

A lei dos senos e um teorema que relaciona as medidas dos lados de um triângulo aos ângulos respectivamente opostos a esses lados.

$$
\frac{a}{\operatorname{sen} \alpha}=\frac{b}{\operatorname{sen} \beta}=\frac{c}{\operatorname{sen} \gamma}
$$

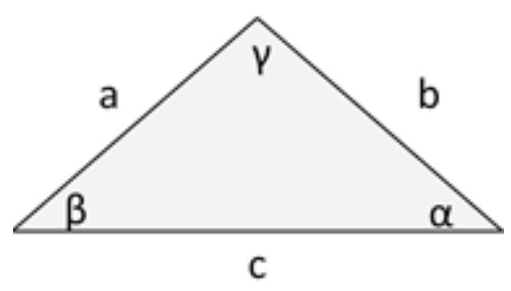

Exemplo 3.5.2.1 Sérgio vai construir, sobre um rio que corta sua propriedade, uma ponte em linha reta ligando dois pontos, A e B, localizados em margens opostas. Para determinar a distância entre esses pontos, um topógrafo localizou um terceiro ponto, C, distante $200 \mathrm{~m}$ do ponto A e na mesma margem onde se encontra o ponto $A$. Sabendo que $o$ ângulo $B C A=30^{\circ}$ e que o ângulo $C A B=105^{\circ}$. Calcule a distância entre os pontos A e B.

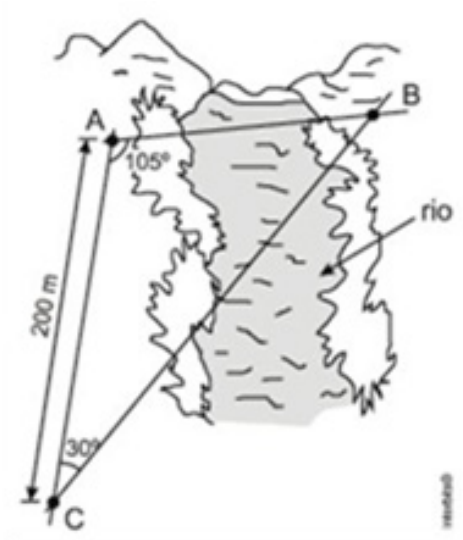

Resolução: Representando graficamente os dados do problema temos: 


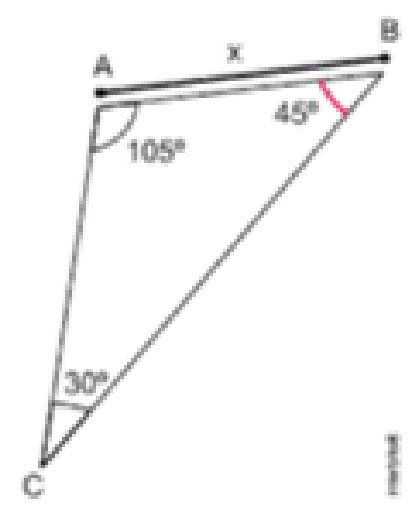

Aplicando a Lei dos Senos, obtemos:

$$
\begin{aligned}
& \frac{X}{\operatorname{sen} 30^{\circ}}=\frac{200}{\operatorname{sen} 45^{\circ}} \\
& \frac{X}{1 / 2}=\frac{200}{\sqrt{2} / 2} \\
& X=\frac{200}{\sqrt{2}} \\
& X=100 \sqrt{2}
\end{aligned}
$$

\subsection{Problemas - Capítulo 3}

Problema 3.6.1 Calcule sen $\alpha, \cos \alpha$ e tg $\alpha$ no triângulo retângulo a seguir.

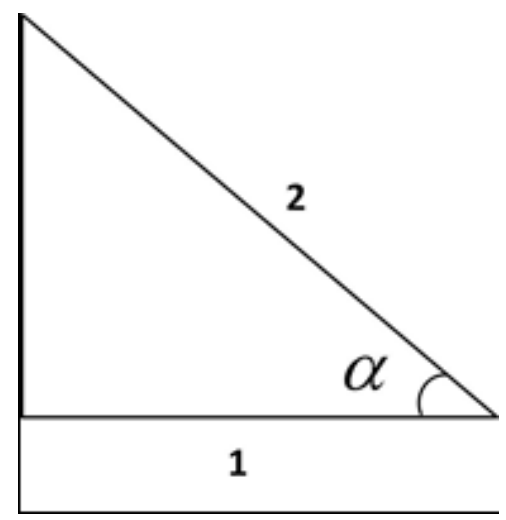

Problema 3.6.2 Calcule a altura h de uma pirâmide regular de base quadrada em função da aresta da base e do ângulo que a aresta lateral forma com o plano da base. 


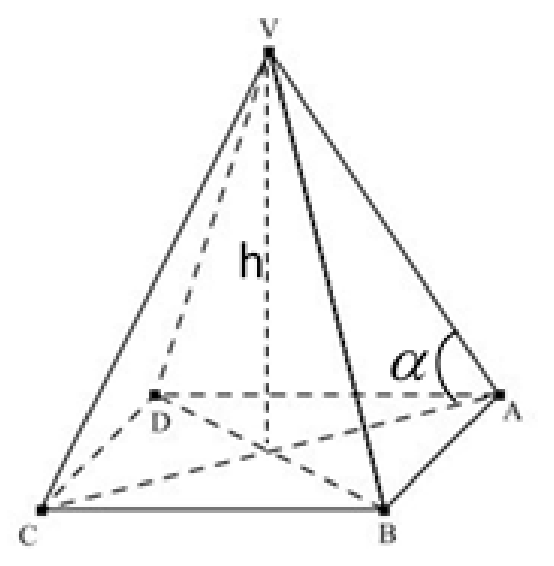

Problema 3.6.3 Calcule a medida X no triângulo retângulo a seguir.

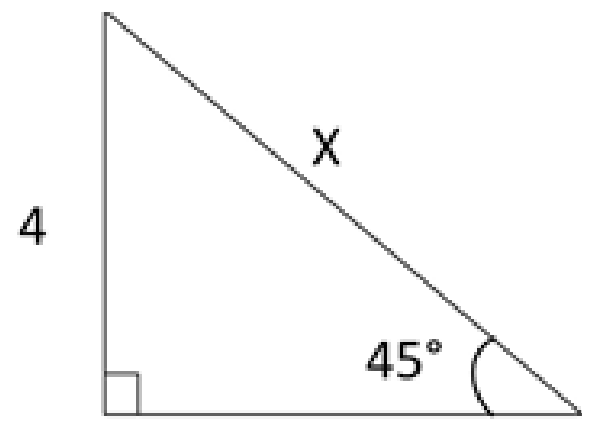

Problema 3.6.4 Calcule a medida X no triângulo retângulo.

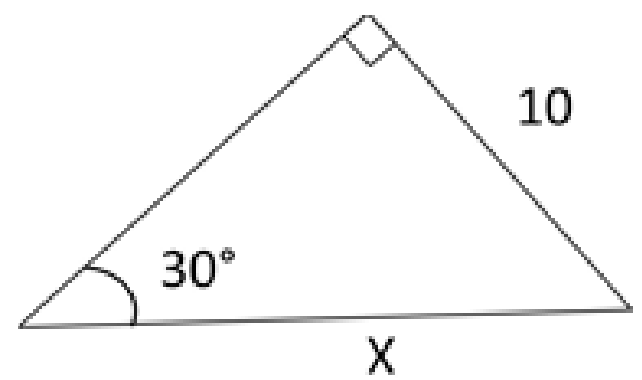

Problema 3.6.5 Um técnico em agropecuária está fazendo um levantamento topográfico em uma propriedade onde será realizado um experimento de irrigação. Ele quer determinar a largura de um pequeno rio que corta a propriedade e por isso adotou os seguintes procedimentos: marcou dois pontos, A (uma árvore que ele observou na outra margem) e B (uma estaca que ele fincou no chão na margem onde ele se encontra); marcou um ponto $C$ distante 6 metros de $B$, fixou o teodolito de tal modo que o ângulo no ponto B seja reto e obteve uma medida de $60^{\circ}$ para o ângulo ACB. Qual foi a largura do rio que ele encontrou?

Problema 3.6.6 Para explorar o potencial turístico de sua propriedade, Walter pre- 
tende construir um teleférico, ligando a estrada ao pico de um morro, conforme ilustra a figura a seguir.

- o ponto de partida fica localizado na estrada (ponto A), com uma parada intermediária (ponto B), e o ponto de chegada localizado no pico do morro (ponto C);

- o ponto de partida ficar localizado no ponto A e o de chegada localizado no ponto $\mathrm{C}$, sem parada intermediária.

Dessa forma, calcule a distância percorrida pelo teleférico para cada uma das possibilidades.

Problema 3.6.7 Duas colheitadeiras partem de um mesmo ponto simultaneamente. A primeira percorre a uma velocidade de $16 \mathrm{~km} / \mathrm{h}$, em curso de $45^{\circ}$ em relação ao norte, no sentido horário. A segunda percorre a uma velocidade de $6 \mathrm{~km} / \mathrm{h}$, em curso de $105^{\circ} \mathrm{em}$ relação ao norte, também no sentido horário. Após uma hora de trabalho, a que distância estarão separadas, supondo que elas tenham mantido o mesmo curso e velocidade constante desde que partiram?

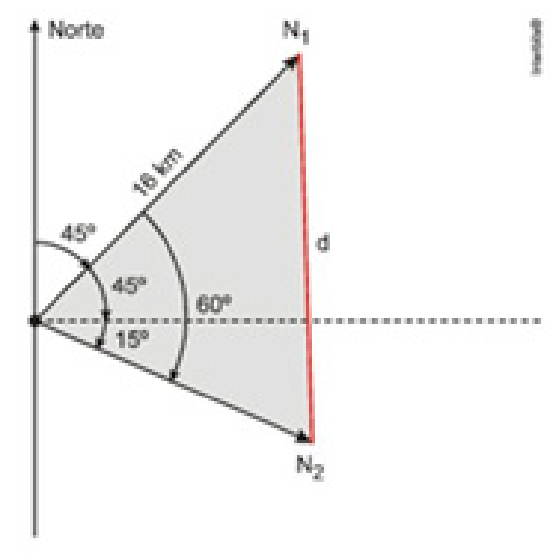

Problema 3.6.8 Na figura a seguir, $\mathrm{ABC}$ e $\mathrm{BDE}$ são triângulos isósceles semelhantes e representam dois morros localizados na fazenda do Sr. Antônio. As bases dos morros medem $200 \mathrm{~m}$ e $100 \mathrm{~m}$ respectivamente e o ângulo $\mathrm{CAB}=30^{\circ}$. Para aproveitar o potencial 
turístico dessa formação montanhosa, Antônio decidiu instalar um teleférico ligando os pontos C e E. Portanto, calcule o comprimento do segmento CE.

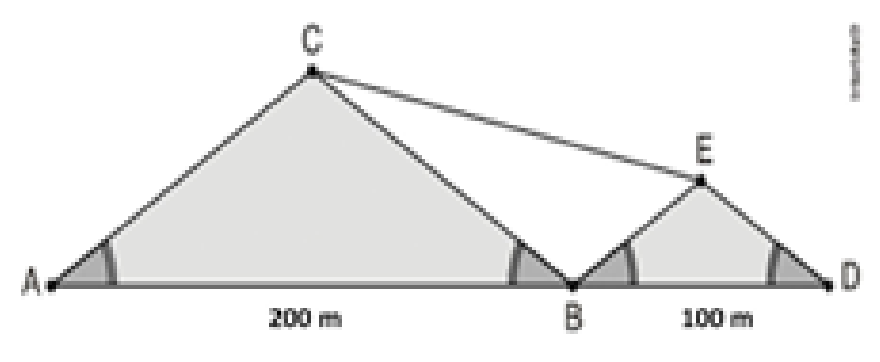

Problema 3.6.9 Um técnico em agropecuária necessita calcular a distância entre pontos situados à margem de um rio, como mostra a figura a seguir. 0 técnico determinou as distâncias mostradas na figura, bem como os ângulos determinados no quadro abaixo, obtidos com um teodolito.

\begin{tabular}{|c|c|}
\hline Visada & Ângulo \\
\hline$A C B$ & $30^{\circ}$ \\
\hline$B C D$ & $60^{\circ}$ \\
\hline$A B C$ & $30^{\circ}$ \\
\hline
\end{tabular}

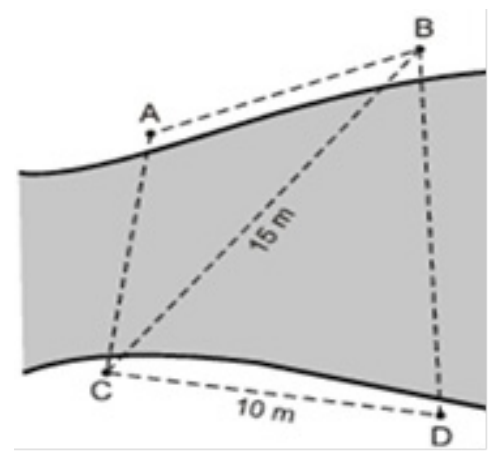

(a) Calcule a distância entre A e B.

(b) Calcule a distância entre B e D.

Problema 3.6.10 No dia 5 de novembro de 2015, no distrito de Bento Rodrigues, em Mariana-MG, uma barragem, se rompeu. Uma lama de rejeitos de minério vazou, arrasou vilas e chegou até o Rio Doce. No Espírito Santo, as cidades afetadas foram Baixo Guandu, Colatina e Linhares, onde fica a foz do rio. A imagem a seguir representa a foz do Rio Doce, situada no município de Linhares-ES, atingida pela lama de rejeitos.

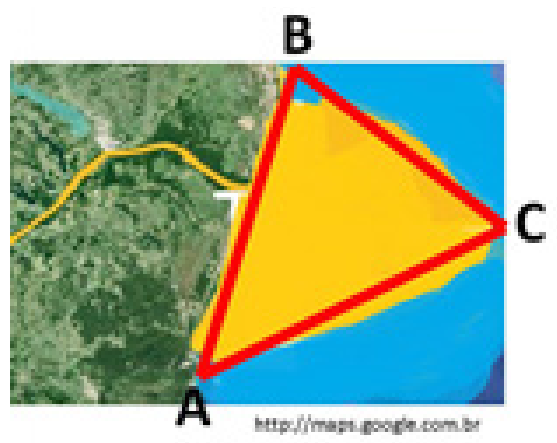

A distância do ponto $\mathrm{B}$ ao ponto $\mathrm{C}$ é de $8 \mathrm{~km}$, o ângulo A mede $45^{\circ}$ e o ângulo C mede $75^{\circ}$. Uma forma de estimar o impacto da lama de rejeitos na foz do Rio Doce é determinar a distância do ponto A ao ponto C. Calcule essa distância.

Problema 3.6.11 Uma ponte deve ser construída sobre um rio, unindo os pontos A e B. Sabendo que BC mede 60 metros. Calcule a distância AB. (Dados: sen $590=0,87$ e sen 
$640=0,90)$

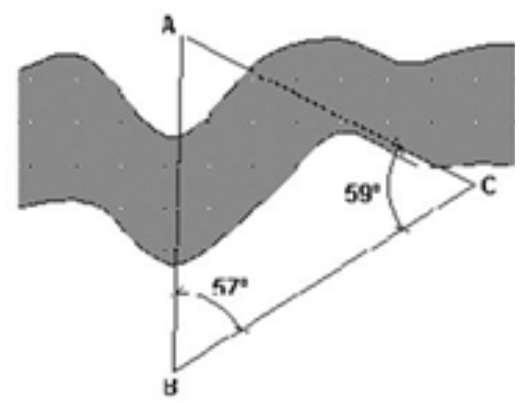




\section{Cálculo Algébrico}

\subsection{Razão e Proporção}

\subsubsection{Razão}

A razão entre dois números $\mathrm{X}$ e $\mathrm{Y}, \operatorname{com} \mathrm{Y} \neq 0$, é o quociente

$$
\frac{X}{Y}
$$

Por meio dessa razão, podemos compreender a relação existente entre X e Y. Algumas razões expressam ideias e significados muito importantes, e por isso são chamadas de razões especiais, tais como: porcentagem, densidade, escala, velocidade média, coeficiente de conversão alimentar, dentre outras.

Exemplo 4.1.1.1 Escala é a razão entre a medida de comprimento no desenho e a medida do comprimento correspondente na realidade.

$$
\text { Escala }=\frac{D}{R}
$$

em que D é a medida do comprimento no desenho e $\mathrm{R}$ é a medida do comprimento real.

Uma escala de 1:1 000 significa que, para cada $1 \mathrm{~cm}$ representado no desenho, tem-se o equivalente a $1000 \mathrm{~cm}$ no comprimento real.

Exemplo 4.1.1.2 A velocidade média é a razão entre a distância percorrida e o tempo gasto.

$$
V m=\frac{\Delta S}{\Delta T}
$$

em que $\Delta S$ é a distância percorrida e $\Delta T$ é o tempo gasto.

\subsubsection{Proporção}

Se duas razões são iguais, então elas formam uma proporção.

$$
\frac{A}{B}=\frac{C}{D}
$$

Exemplo 4.1.2.1 As razões $\frac{2}{5}$ e $\frac{4}{10}$ são iguais. Logo, elas formam uma proporção. 


$$
\frac{2}{5}=\frac{4}{10}
$$

\subsubsection{Propriedade Fundamental das Proporções}

Seja $\frac{A}{B}=\frac{C}{D}$ uma proporção. Então, $A D=B C$.

Em toda proporção, o produto dos meios é igual ao produto dos extremos.

Exemplo 4.1.2.1.1 Podemos usar a propriedade fundamental das proporções para encontrar um valor desconhecido na proporção. Considere a proporção $\frac{X}{5}=\frac{4}{10}$. Então, pela propriedade fundamental das proporções, segue que:

$$
\begin{aligned}
& 10 X=20 \\
& X=\frac{20}{10} \\
& X=2
\end{aligned}
$$

\subsection{Grandezas Proporcionais}

\subsubsection{Ideias Preliminares}

Grandeza é tudo aquilo que pode ser medido ou contado. Exemplos: comprimento, largura, altura, massa, velocidade, força, corrente elétrica, aceleração, idade, preço, tempo, quantidade de café produzido, área, volume, perímetro, capacidade, temperatura, umidade. Para cada grandeza, temos uma unidade de medida padrão apropriada.

Exemplos: quilograma, segundo, metro, toneladas, metros por segundo, litro, grau Celsius.

\subsubsection{Grandezas diretamente proporcionais}

Duas grandezas são ditas diretamente proporcionais quando, ao dobrar, triplicar ou reduzir à metade o valor de uma, isso, implica em que o valor da outra também dobra, triplica ou é reduzido a metade, e assim por diante.

Exemplo 4.2.2.1 0 preço do aluguel de uma máquina agrícola é de $\mathrm{R} \$ 300,00$ por hora. Quanto um agricultor pagará pelo aluguel dessa máquina por um período de 3 horas? 


\begin{tabular}{|c|c|}
\hline Tempo (hora) & Preço (R\$) \\
\hline 1 & 300 \\
\hline 3 & 900 \\
\hline
\end{tabular}

$300 \times 3=900$.

Portanto, o valor pago será de R $\$ 900,00$.

Em casos como esses dizemos que as grandezas correspondentes ao preço do aluguel e às horas de uso são diretamente proporcionais.

\subsubsection{Grandezas inversamente proporcionais}

Duas grandezas são ditas inversamente proporcionais quando, ao multiplicar por um número o valor de uma, isso implica em que o valor da outra será dividido pelo mesmo número, isto é, se uma dobra, a outra é reduzida à metade, se uma triplica, a outra é reduzida à terça parte, e assim por diante.

Exemplo 4.2.3.1 Uma torneira que despeja 50 litros de água enche um reservatório em 1 hora. Se essa torneira despejasse 100 litros de água por hora, em quanto tempo encheria o mesmo reservatório?

\section{Resolução:}

\begin{tabular}{|c|c|}
\hline Tempo (hora) & Preço (R\$) \\
\hline 1 & 50 \\
\hline 0,5 & 100 \\
\hline
\end{tabular}

$$
1: 2=0,5
$$

Portanto, a torneira encheria o reservatório em 0,5 horas ou 30 minutos.

Em casos como esses, dizemos que as grandezas correspondentes ao tempo gasto para encher o reservatório e à vazão da torneira são inversamente proporcionais. 


\subsection{Regra de três}

\subsubsection{Regra de três simples aplicada em situações de proporcio- nalidade direta}

Exemplo 4.3.1.1 Se com $50 \mathrm{~kg}$ de acerola é possível produzir 35 litros de suco. Quantos litros de suco são produzidos com $80 \mathrm{~kg}$ de acerola?

Resolução: Primeiro observamos que a quantidade de fruta e a quantidade de litros de suco produzidos são grandezas diretamente proporcionais, pois quanto mais quantidade de massa de fruta disponível, mais suco poderá ser produzido. Com efeito, se dobrarmos a quantidade de fruta vamos dobrar a produção de suco, se triplicarmos a quantidade de fruta, vai triplicar a quantidade de suco, e assim por diante.

\begin{tabular}{|c|c|}
\hline $\begin{array}{c}\text { Quantidade de } \\
\text { fruta (kg) }\end{array}$ & $\begin{array}{c}\text { Quantidade de } \\
\text { suco (1) }\end{array}$ \\
\hline 50 & 35 \\
\hline 80 & $\mathrm{X}$ \\
\hline
\end{tabular}

$$
\begin{aligned}
& \frac{35}{X}=\frac{50}{80} \\
& 50 X=2800 \\
& X=560
\end{aligned}
$$

Portanto, com $80 \mathrm{~kg}$ de acerola é possível produzir 560 litros de suco.

Exemplo 4.3.1.2 Sabendo que 30 quilos de cenoura custam $R \$ 75,00$. Quanto custará 105 quilos?

Resolução: Quanto maior for a quantidade de cenouras compradas, maior será o valor pago. De modo que, se dobrarmos a quantidade de cenouras, o valor pago também dobrará, se triplicarmos a quantidade de cenouras compradas, o valor pago também triplicará, e assim por diante. Então, a quantidade de cenouras compradas e o valor pago por elas são grandezas que se relacionam de modo diretamente proporcional.

\begin{tabular}{|c|c|}
\hline $\begin{array}{c}\text { Quantidade de } \\
\text { cenoura (kg) }\end{array}$ & Valor pago (R\$) \\
\hline 30 & 75 \\
\hline 105 & $\mathrm{X}$ \\
\hline
\end{tabular}




$$
\begin{aligned}
& \frac{75}{X}=\frac{30}{105} \\
& 30 X=7875 \\
& X=262,50
\end{aligned}
$$

Portanto, o valor por $105 \mathrm{~kg}$ de cenoura será de $\mathrm{R} \$ 262,50$.

\subsubsection{Regra de três simples aplicada em situações de proporcio- nalidade inversa}

Exemplo 4.3.2.1 Quatro tratores realizam uma tarefa em 9 dias. Em quantos dias 6 tratores farão a mesma tarefa nas mesmas condições?

Resolução: Quanto maior for a quantidade de tratores executando uma determinada tarefa, menos dias serão necessários para concluí-la. De modo que, se dobrarmos a quantidade de tratores, gastaremos a metade do tempo inicial, se triplicarmos a quantidade de tratores, gastaremos a terça parte do tempo inicial, e assim por diante. Portanto, a quantidade de tratores e o tempo gasto são grandezas que se relacionam de modo inversamente proporcional.

\begin{tabular}{|c|c|}
\hline $\begin{array}{c}\text { Quantidade de } \\
\text { tratores }\end{array}$ & Tempo (dias) \\
\hline 4 & 9 \\
\hline 6 & $\mathrm{X}$ \\
\hline \multicolumn{3}{|c|}{$=\frac{6}{4}$} \\
$6 X=36$ \\
$X=6$ \\
\end{tabular}

Portanto, 6 tratores realizarão a mesma tarefa, nas mesmas condições, em 6 dias.

Exemplo 4.3.2.2 Sabendo que 9 trabalhadores constroem um cerca em 12 dias. Quantos trabalhadores serão necessários para construir a mesma cerca em 27 dias?

Resolução: Quanto maior for a quantidade de trabalhadores, menos dias serão necessários para construir a cerca. De modo que, se dobrarmos a quantidade de trabalhadores, o tempo gasto para construir a cerca será a metade do tempo inicial, se triplicarmos a quantidade de trabalhadores, o tempo gasto para construir a cerca será a terça parte 
do tempo inicial, e assim por diante. Portanto, a quantidade de trabalhadores e o tempo gasto são grandezas que se relacionam de modo inversamente proporcional.

\begin{tabular}{|c|c|}
\hline $\begin{array}{c}\text { Quantidade de } \\
\text { trabalhadores }\end{array}$ & Tempo (dias) \\
\hline 9 & 2 \\
\hline $\mathrm{X}$ & 27 \\
\hline
\end{tabular}

$$
\begin{aligned}
& \frac{9}{X}=\frac{27}{12} \\
& 27 X=108 \\
& X=4
\end{aligned}
$$

Portanto, 27 trabalhadores construirão a mesma cerca em 4 dias.

\subsection{Regra de três composta}

Os problemas de regra de três composta envolvem mais de duas grandezas, de modo que, tomadas duas a duas, elas sejam proporcionais direta ou inversamente.

Exemplo 4.4.1 Com $600 \mathrm{~kg}$ de ração é possível alimentar 20 vacas durante 30 dias. Com $800 \mathrm{~kg}$ da mesma ração é possível alimentar 25 vacas durante quantos dias?

Resolução: A quantidade de ração e o número de dias são inversamente proporcionais, considerando o mesmo número de animais. 0 número de animais e o número de dias são inversamente proporcionais, considerando fixa a quantidade de ração.

\begin{tabular}{|c|c|c|}
\hline Ração (kg) & Animais & Dias \\
\hline 600 & 20 & 30 \\
\hline 800 & 25 & $\mathrm{X}$ \\
\hline
\end{tabular}

Para escrever a proporção, primeiro fixamos no primeiro membro da igualdade a coluna em que se encontra a incógnita. Em seguida, completamos o segundo membro da igualdade com o produto das frações formadas pelas demais colunas. Lembrando que, se uma coluna representar uma grandeza inversamente proporcional à grandeza representada pela incógnita devemos inverter o seu numerador pelo denominador. Com efeito, obtemos: 


$$
\begin{aligned}
& \frac{30}{X}=\frac{800}{600} \cdot \frac{25}{20} \\
& \frac{30}{X}=\frac{15000}{16000} \\
& \frac{30}{X}=\frac{15}{16} \\
& 15 X=480 \\
& X=32
\end{aligned}
$$

\subsection{Regra de Sociedade}

A regra de sociedade, é uma aplicação da divisão em partes proporcionais. Ela pode ser empregada na divisão de lucro, dívida ou qualquer outra grandeza, de modo a ponderar a medida da participação (porcentagem) de cada elemento dentro de uma parceria, uma sociedade, um formulado, dentre outros.

Exemplo 4.5.1 Observe, a seguir, o detalhamento de um projeto executado por uma sociedade.

\begin{tabular}{ll}
\hline \multicolumn{2}{c}{ Objetivo: produzir $\mathbf{5 0 0}$ mil mudas de café } \\
\hline Despesa provável: & $\mathrm{R} \$ 450.000,00$ \\
\hline Investimento: & \\
\hline Sócio A: & $\mathrm{R} \$ 150.000,00$ \\
\hline Sócio B: & $\mathrm{R} \$ 180.000,00$ \\
\hline Sócio C: & $\mathrm{R} \$ 120.000,00$ \\
\hline Receita provável: & $\mathrm{R} \$ 1.350 .000,00$ \\
\hline
\end{tabular}

Calcule o lucro obtido por cada sócio, proporcional ao investimento de cada um deles.

Resolução: Sejam X,Y e Z o lucro proporcional dos sócios A,B e C respectivamente. Como a divisão do lucro deve ser feita proporcionalmente ao investimento realizado por cada um deles, obtemos:

$$
\frac{X}{150000}=\frac{Y}{180000}=\frac{Z}{120000}=\frac{X+Y+Z}{150000+180000+120000}=\frac{1350000}{450000}=3
$$


Com efeito, obtemos:

$$
\begin{aligned}
& \frac{X}{150000}=3 \Rightarrow X=450000 \\
& \frac{Y}{180000}=3 \Rightarrow Y=540000 \\
& \frac{Z}{120000}=3 \Rightarrow Z=360000
\end{aligned}
$$

Portanto, o sócio A deverá receber $\mathrm{R} \$ 450.000,00$; o sócio $\mathrm{B}, \mathrm{R} \$ 540.000,00$; e o sócio C, $\mathrm{R} \$ 360.000,00$.

Exemplo 4.5.2 Analise a tabela de adubação química para a cultura da batata em estágio de plantio aplicado em sulco.

\begin{tabular}{|c|c|c|}
\hline Cultura & Fórmula & Dosagem \\
\hline Batata & $04-14-08$ & $3000-4000 \mathrm{~kg} / \mathrm{ha}$ \\
\hline
\end{tabular}

Calcule as partes proporcionais das quantidades indicadas de N, P e K para a cultura da batata.

Resolução: Sejam X, Y e Z, as partes proporcionais de N, P e K respectivamente. Sabemos que $\mathrm{X}, \mathrm{Y}$ e $\mathrm{Z}$, devem ser diretamente proporcionais a 4, 14 e 8 respectivamente. Considerando uma aplicação de $3120 \mathrm{~kg} / \mathrm{ha}$ desse formulado, obtemos:

$$
\frac{X}{4}=\frac{Y}{14}=\frac{Z}{8}=\frac{X+Y+Z}{4+14+8}=\frac{3120}{26}=120
$$

Dessa forma, obtemos:

$$
\begin{aligned}
& \frac{X}{4}=120 \Rightarrow X=480 \\
& \frac{Y}{14}=120 \Rightarrow Y=1680 \\
& \frac{Z}{8}=120 \Rightarrow Z=960
\end{aligned}
$$

Portanto, para a elaboração desse formulado são necessárias as quantidades de $120 \mathrm{~kg}$ de N, 480kg de P e $960 \mathrm{~kg}$ de K para cada hectare. 


\subsection{Porcentagem}

Uma porcentagem (\%) é uma fração de denominador 100.

Usamos a notação de porcentagem em diversos aspectos do nosso dia a dia. Aprender a usá-la de maneira correta pode melhorar nossa habilidade em diversas atividades. Uma boa notícia é que, se ampliarmos nossas experiências com as várias formas de aplicação da porcentagem, nossa capacidade de trabalhar com elas certamente irá aumentar. A porcentagem é uma linguagem muito conveniente para representar a divisão de um todo em partes diferentes.

Suponha que os custos de produção de certa cultura estejam divididos em partes que mostram a participação de cada processo: adubação, 1/5; irrigação, 3/20; máquinas, 1/4, etc. Dessa forma, não é evidente reconhecer qual dos processos é o mais oneroso na produção dessa cultura. Entretanto, escrever tais números em porcentagens, 20\%, 15\% e 25\%, faz com que a informação seja transmitida com mais clareza.

Exemplo 4.6.1 Um técnico em agropecuária, cujo salário é de $\mathrm{R} \$ 3.500,00$, recebe um aumento de 3\%. Qual é o seu novo salário?

\section{Resolução:}

$$
3 \% \text { de } 3500=\frac{3}{100} \cdot 3500=3 \times 35=105 .
$$

Logo, o novo salário será de $3500+105=3605$ reais.

Exemplo 4.6.2 O uso de porcentagens está tão presente em nosso cotidiano, que é conveniente termos os significados de algumas delas assimilados.

- $100 \%=$ todo

- $60 \%$ = um pouco mais da metade

- $50 \%=$ metade

- $\mathbf{4 0 \%}=$ pouco menos da metade

- $30 \%$ = quase um terço

- $25 \%$ = a quarta parte

- $20 \%=$ um quinto

- $5 \%$ = um vigésimo

- $1 \%$ = um centésimo 
Exemplo 4.6.3 Um equívoco muito comum é entre pontos percentuais e a porcentagem real. Um aumento de dois pontos percentuais na taxa de juros significa que a porcentagem que representa essa taxa cresceu dois pontos: de $15 \%$ para $17 \%$, por exemplo. 0 que é diferente de um aumento de $2 \%$.

Exemplo 4.6.4 $\mathrm{O}$ segredo para aumentar a habilidade de resolver porcentagens mentalmente, é fazer associação com porcentagens facilmente conhecidas como: 10\%, 50\%. Então, para calcularmos quanto é $5 \%$ de 280 , basta calcular quanto vale $10 \%$ e dividir por 2.

Então, $5 \%$ de 280 é igual a 14 , pois $10 \%$ de $280=28$ e $28: 2=14$.

Sendo assim, a partir de $10 \%$, podemos calcular mentalmente porcentagens como: $5 \% ; 15 \% ; 20 \% ; 25 \%, 75 \% ; 85 \%$.

Exemplo 4.6.5 $\mathrm{Na}$ adubação em cobertura de uma determinada cultura, será necessária a aplicação de $220 \mathrm{~kg} /$ ha de nitrogênio (N). $\mathrm{O}$ fertilizante será o sulfato de amônio ( $25 \%$ de N). Qual é a quantidade de sulfato de amônio, em kg/ha, a ser utilizada?

Resolução: A quantidade de 220kg/ha de nitrogênio necessária corresponde a 25\%, a quarta parte, do total de sulfato de amônio a ser utilizado. Então a quantidade de fertilizante será:

$$
\begin{aligned}
& 25 \% \text { de } \mathrm{X}=220 \\
& \frac{25 X}{100}=220 \\
& 25 X=22000 \\
& X=880
\end{aligned}
$$

Portanto, serão necessários $880 \mathrm{~kg} / \mathrm{ha}$ de sulfato de amônio.

Exemplo 4.6.6 Leia a reportagem a seguir.

A expectativa era a indústria de semente crescer ao longo do ano passado, na esteira das boas safras de soja e milho do ciclo produtivo de 2014/2015.

Na safra 2014/2015, a indústria produziu cerca de 2,3 milhões de toneladas de sementes no país, sendo 1,8 milhão de toneladas de soja e 536000 toneladas de milho.

Fonte: ABAIXO do esperado. Revista GloboRural, n. 363,p.36, jan.2016.

De acordo com o texto, a produção de sementes de soja, representou na safra 2014/2015, aproximadamente, qual porcentagem do total de sementes produzidas? 
Resolução: A maneira mais comum de obter esse resultado é por meio de uma regra de três.

$$
\begin{aligned}
& 2,3 \rightarrow 100 \% \\
& 1,8 \% \rightarrow X
\end{aligned}
$$

Então, obtemos:

$$
\begin{aligned}
& 2,3 X=180 \\
& X=\frac{180}{2,3} \\
& X=78,26
\end{aligned}
$$

Portanto, a produção de sementes de soja, representou na safra 2014/2015, aproximadamente, $78,26 \%$ da produção total de sementes.

\subsection{Quadrado de Pearson com duas matérias primas para acerto de um nutriente}

Dominar o conhecimento sobre a composição e o valor energético dos alimentos, é essencial para a formulação de uma ração rica em nutrientes, e para aperfeiçoar os custos da produção. A tabela a seguir mostra a composição química do milho, do sorgo de baixo tanino e do farelo de soja.

Tabela 4.7.1 - Valores obtidos de Rostagno et al. (2005)

\begin{tabular}{cccc} 
Nutriente/Ingrediente & Milho & Sorgo & Farelo de soja \\
\hline Matéria Seca (\%) & 87,11 & 87,97 & 88,59 \\
\hline Proteína Bruta (\%) & 8,26 & 9,23 & 45,32 \\
\hline Lisina (\%) & 0,24 & 0,20 & 2,77 \\
\hline Gordura (\%) & 3,61 & 3,00 & 1,66 \\
\hline Matéria Mineral (\%) & 1,27 & 1,86 & 5,90 \\
\hline Energia Bruta (kcal/kg) & 3,925 & 3,928 & 9,079
\end{tabular}

O procedimento para a formulação de rações segue algumas etapas. A primeira etapa é a classificação dos animais por fase, levando em conta suas características de idade ou peso (massa). A segunda, é a definição das necessidades nutricionais dos animais, que podem ser representadas em termos absolutos ou em termos relativos, isto é, em porcentagem. A última, é a escolha dos alimentos e ingredientes que devem ser combinados, 
de modo a proporcionar uma formulação de ração que seja adequada quanto ao aspecto nutricional, palatável aos animais e economicamente viável ao produtor.

Para balancear uma ração, vamos utilizar o Quadrado de Pearson, um método simples de ser usado para a formulação de ração envolvendo dois alimentos ou grupos de alimentos previamente misturados.

Acompanhe passo a passo a descrição do método de aplicação do Quadrado de Pearson

- desenhar um quadrado, e colocar no seu interior, o percentual desejado do nutriente;

- colocar as porcentagens dos nutrientes, presentes em cada um dos alimentos/ingredientes nos vértices situados à esquerda;

- subtrair diagonalmente, o valor de cada vértice, pelo valor central, e considerar o resultado em módulo;

- o valor no centro do quadrado, precisa estar dentro do intervalo determinado pelos valores situados nos vértices;

- calcular a porcentagem de cada alimento/ingrediente, em relação ao total;

- verificar se a ração, atende às exigências nutricionais dos animais.

Exemplo 4.7.1 Deseja-se balancear uma ração para suínos em fase de crescimento, de médio porte de potencial genético. As tabelas a seguir, mostram as exigências desses animais, e os alimentos disponíveis com suas respectivas composições.

Tabela 4.7.2 - Exigências nutricionais para suínos de desempenho médio na fase de crescimento

\begin{tabular}{lc}
\hline Nutrientes & Exigêngias \\
\hline Enetgia Metabolizavel (kcal/kg) & 3.230 \\
\hline Proteína (\%) & 15,43 \\
\hline Cálcio (\%) & 0,551 \\
\hline Fosforo (\%) & 0,459 \\
\hline Sodio (\%) & 0,170 \\
\hline
\end{tabular}

Tabela 4.7.3 - Composição química dos alimentos disponíveis

\begin{tabular}{lcr}
\hline Alimentos & EM (kcal/kg) & PB \\
\hline Milho Grão & 3340 & 8,26 \\
\hline Farelo de Soja & 3154 & 45,32 \\
\hline
\end{tabular}


Determine a quantidade necessária de cada alimento, para satisfazer a exigência de proteína bruta $(\mathrm{PB})$ para suíno de médio porte.

Resolução: Aplicando o Quadrado de Pearson, obtemos:

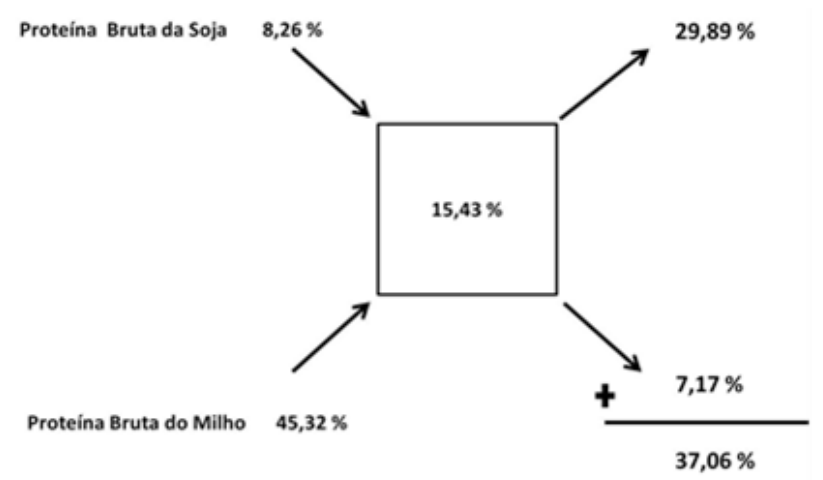

Então, para determinar a quantidade de inclusão de milho, basta calcular a porcentagem de milho em relação ao total.

$$
29,89 \div 37,06=0,80=80 \%
$$

Portanto, a quantidade de inclusão de milho é de $80 \%$. Para determinarmos a quantidade de inclusão de soja, fazemos:

$$
7,17 \div 37,06=0,20=20 \%
$$

Agora é necessário verificar se essa composição atende às exigências nutricionais dos animais.

Proteína: 80 x 8,26\% + 20 x 45,32\% = 15,67.

Energia Metabolizável: 0,80 x $3340+0,20$ x $3154=3$ 302,80.

Portanto, a ração, composta formada por, $80 \%$ de milho e $20 \%$ de farelo de soja, atende às exigências nutricionais, para os parâmetros de proteína bruta e energia metabolizável, para suínos de médio porte.

\subsection{Problemas - Capítulo 4}

Problema 4.8.1 Calcule a razão entre os números abaixo na forma de fração irredutível:
(a) 20 e 45
(c) 40 e 100
(d) 12 e 144
(b) 56 e 112 
Problema 4.8.2 Observe a sequência de Fibonacci

$$
1,1,2,3,5,8,13,21,34,55,89,144, \ldots
$$

em que cada termo, a partir do terceiro, é a soma dos dois imediatamente anteriores. Calcule a razão entre os termos consecutivos. Expresse os resultados na forma decimal com até 5 casas decimais. Exemplo:

$$
\frac{5}{3}=1,666 \ldots
$$

Problema 4.8.3 Use as propriedades das proporções e calcule o valor de x em cada proporção.
(a) $\frac{5}{3}=\frac{X}{12}$
(b) $\frac{2}{X+1}=\frac{9}{6}$

\section{Problema 4.8.4}

(a) Para alugar uma máquina agrícola por 2 horas, Pedro gastou $\mathrm{R} \$ 500,00$. Quanto ele irá gastar, para alugar essa mesma máquina por 10 horas?

(b) Identifique se as grandezas correspondentes no item acima são diretamente proporcionais ou inversamente proporcionais.

\section{Problema 4.8.5}

(a) Uma máquina agrícola gasta 5 horas para realizar o plantio de 3 hectares uma certa cultura. Quanto tempo essa mesma máquina gastaria para realizar o plantio de 9 hectares dessa mesma cultura?

(b) Identifique se as grandezas correspondentes no item acima são diretamente proporcionais ou inversamente proporcionais.

\section{Problema 4.8.6}

(a) Uma torneira que despeja 150 litros de água por hora, enche um reservatório em 3 horas. Se essa torneira despejasse 450 litros de água por hora, em quanto tempo encheria o mesmo reservatório?

(b) Identifique se as grandezas correspondentes no item acima são diretamente proporcionais ou inversamente proporcionais.

\section{Problema 4.8.7}

(a) Se em $1 \mathrm{~g}$ de sementes de mamão temos 60 sementes. Quantas sementes de mamão terão em $8 g$ ? 
(b) Identifique se as grandezas correspondentes no item acima são diretamente proporcionais ou inversamente proporcionais.

\section{Problema 4.8.8}

(a) Sabendo que para produzir $1 \mathrm{~kg}$ de filé de tilápia são necessários $3 \mathrm{~kg}$ de tilápia. Quantos quilos de tilápia são necessários para produzir $12 \mathrm{~kg}$ de filé de tilápia?

(b) Identifique se as grandezas correspondentes no item acima são diretamente proporcionais ou inversamente proporcionais.

Problema 4.8.9 Um carro com velocidade média de $80 \mathrm{~km} / \mathrm{k}$, percorre qual distância em 2h20min?

Problema 4.8.10 Se um pedaço de queijo, de $600 \mathrm{~g}$ custa $\mathrm{R} \$ 12,60$. Quanto custa um pedaço de $1,2 \mathrm{~kg}$ desse mesmo queijo?

Problema 4.8.11 Três torneiras despejam 50001 de água em um reservatório em 5 horas. Em quantas horas 6 torneiras, do mesmo tipo, despejam 60001 de água?

Problema 4.8.12 Com 450kg de tilápia, são produzidos 150kg de filé de tilápia. Quantos quilos de filé de tilápia são produzidos com 1,5 tonelada de tilápia?

Problema 4.8.13 O capim de um terreno cresce em toda sua extensão com igual rapidez e espessura. Sabe-se que 70 vacas comeriam o capim em 24 dias, enquanto que 30 vacas o comeriam em 60 dias. Quantas vacas comeriam o capim em 96 dias?

Problema 4.8.14 Uma colheitadeira, trabalhando 6 minutos, colhe 80 quilos de grãos. Se for usada uma máquina com o dobro da capacidade de trabalho, em quanto tempo ela colherá 120 quilos? (Sugestão: use 1 para a capacidade de trabalho da primeira máquina e 2 para a segunda.)

Problema 4.8.15 Um fazendeiro possui ração suficiente para alimentar suas 16 ovelhas durante 62 dias. Após 14 dias, ele vende 4 ovelhas. Passados mais 15 dias, ele compra 9 ovelhas. Quantos dias, no total, durará sua reserva de ração?

Problema 4.8.16 Um fazendeiro, na safra passada, usou 12 trabalhadores para colher sua plantação de tomate de 120 hectares. Trabalhando 6 horas por dia, os trabalhadores concluíram o trabalho em uma semana. Este ano, o fazendeiro plantou 180 hectares e dispõe de 14 trabalhadores, dispostos a trabalhar 8 horas por dia, durante 5 dias. Quantos hectares de tomate esses trabalhadores conseguirão colher? 
Problema 4.8.19 Um terreno de 6 hectares teve sua grama podada por 4 homens que trabalharam 6 horas por dia durante 3 dias. Quantos homens com a mesma capacidade de trabalho seriam necessários para realizar a mesma tarefa em um terreno de $8000 \mathrm{~m} 2$ trabalhando 8 horas por dia em 2 dias?

Problema 4.8.20 Sabendo que 75 vacas consomem em 12 dias o capim de um pasto de 60 acres, e que 81 vacas consomem em 15 dias o capim de outro pasto de 72 acres. Qual o número de vacas que serão necessárias para consumir em 18 dias o capim de um pasto de 96 acres, supondo que nos três pastos, o capim possui a mesma altura, e continua crescendo uniformemente?

Problema 4.8.21 Um engenheiro calculou que seriam necessários 75 homens, trabalhando 8 horas por dia, para concluir um galpão em 220 dias. Quantos homens seriam necessários para concluir o galpão em 150 dias, trabalhando 10 horas por dia?

Problema 4.8.22 Observe, a seguir, o detalhamento de um projeto executado por uma sociedade.

\begin{tabular}{lr}
\hline \multicolumn{2}{c}{ Objetivo: produzir $\mathbf{6 0 0}$ mil mudas de banana } \\
\hline Despesa provável & $\mathrm{R} \$ 250000,00$ \\
\hline Investimentos & $\mathrm{R} \$ 50000,00$ \\
\hline Sócio A: & $\mathrm{R} \$ 75000,00$ \\
\hline Sócio B: & $\mathrm{R} \$ 125000,00$ \\
\hline Sócio C: & $\mathrm{R} \$ 500000,00$
\end{tabular}

Calcule o lucro obtido por cada sócio, proporcional ao investimento de cada um deles.

Problema 4.8.23 Alberto, Bruno, Carla e Daniel, aplicaram, respectivamente, a quantia de $\mathrm{R} \$ 30$ 000,00, R\$ 10 000,00, R\$ 20 000,00 e R\$ 40 000,00. Com esse investimento, eles obtiveram um lucro no valor de $\mathrm{R} \$ 300$ 000,00. Como deve ser feita a divisão proporcional desse lucro?

Problema 4.8.24 Analise a tabela de adubação química para a cultura de cana-de-açúcar em estágio de plantio aplicado em sulco.

\begin{tabular}{c|c|c}
\hline Cultura & Fórmula & Dosagem \\
\hline Cana-de-açúcar & $04-20-20$ & $600 \mathrm{~kg} / \mathrm{ha}$ \\
\hline
\end{tabular}

Calcule as partes proporcionais das quantidades indicadas de N, P e K para essa cultura. 
Problema 4.8.25 Divida o número 200 em partes proporcionais a 4 e 6. Em seguida, divida o número 200, em partes proporcionais a 8 e 12. Explique por que os resultados são iguais.

Problema 4.8.26 Analise a tabela de adubação química para a cultura de milho em estágio de plantio aplicado em sulco.

\begin{tabular}{c|c|c}
\hline Cultura & Fórmula & Dosagem \\
\hline milho & $04-31-16$ & $250 \mathrm{~kg} / \mathrm{ha}$ \\
\hline
\end{tabular}

Calcule as partes proporcionais das quantidades indicadas de N, P e K para essa cultura.

Problema 4.8.27 Calcule:
(a) $1000 \%$ de 2
(b) $12 \%$ de 800
(c) $0,75 \%$ de 264 .
(d) $37 \%$ de 9600
(e) $2 \%$ de 400

Problema 4.8.28 Em um determinado mês, o valor da saca de café registrou uma queda de $12 \%$, e no mês seguinte, outra queda de $15 \%$.
(a) Qual foi a queda percentual total?
(b) Se a queda no valor de $15 \%$ tivesse vindo primeiro e a queda de $12 \%$ depois, isso teria influenciado no valor final?

Problema 4.8.29 Em um determinado mês, um trabalhador rural teve um aumento salarial de $5 \%$, e, no mês seguinte, um novo aumento de $8 \%$.
(a) Qual foi o aumento percentual do seu salário após esses dois aumentos consecutivos?
(b) Teria sido mais vantajoso para o trabalhador se o aumento percentual de $8 \%$ tivesse vindo primeiro?

Problema 4.8.30 Complete a tabela abaixo.

\begin{tabular}{l|r|r|r}
\hline & X & Y & Z \\
\hline Preço antigo & 60 & 200 & 4000 \\
\hline $\begin{array}{l}\text { Porcentagem do } \\
\text { aumento }\end{array}$ & $5 \%$ & $28 \%$ & $35 \%$ \\
\hline Aumento em reais & & & \\
\hline Novo preço & & & \\
\hline
\end{tabular}


Problema 4.8.31 Após uma negociação com um cliente, ficou acertado que o mesmo vai consumir $325 \mathrm{~kg}$ de filé de tilápia por semana. De acordo com o planejamento responda as seguintes perguntas:

(a) quantos quilos de ração por mês serão consumidos e quanto será gasto em ração, sabendo que a conversão alimentar é de 1,4:1,0 e que o preço da ração é de $\mathrm{R} \$ 1,20 / \mathrm{kg}$ ?

(b) qual o custo total por kg de peixe, sabendo que o custo da ração representa $60 \%$ do custo total?

(c) qual o custo total, sabendo que $1 \mathrm{~kg}$ de filé de tilápia necessita de $3 \mathrm{~kg}$ de tilápia e que o processamento dele dentro do frigorífico aumenta o preço em $14 \%$ ?

Problema 4.8.32 Em uma microbacia hidrográfica, o mês de abril registrou $100 \mathrm{~mm}$ de chuva. Sabendo que, $50 \%$ desse volume infiltrou-se no solo, ocorrendo em seguida uma perda por evaporação de 15\%. Qual é o volume de água, em litros, disponível nesse período para uma lavoura de 0,5ha de café?

Problema 4.8.33 Sabendo que, um determinado saco de sementes de $40 \mathrm{~kg}$ contém a informação de que a porcentagem de germinação das sementes é de $80 \%$ e o peso de 100 sementes é de 20g. Quantos sacos de semente serão necessários para efetuar o plantio de 12ha de uma cultura cujo espaçamento de plantio é de $45 \mathrm{~cm}$ entre linhas, com uma população final de 18 plantas por metro linear?

Problema 4.8.34 Na adubação em cobertura da cultura da bananeira, será necessária a aplicação de $120 \mathrm{~kg} /$ ha de nitrogênio (N). 0 fertilizante será o sulfato de amônio (20\% de $\mathrm{N})$. Qual é a quantidade de sulfato de amônio, em $\mathrm{kg} / \mathrm{ha}$, a ser utilizada?

Problema 4.8.35 Na regulagem de semeadoras adubadoras, uma importante etapa é, determinar a quantidade de sementes a ser utilizada. Sabe-se que a população desejada em um plantio de milho é de 50.000 plantas por hectare, que o poder germinativo das sementes é de $80 \%$ e que o índice de sobrevivência é de $90 \%$. Qual é o número aproximado de sementes por hectare?

Problema 4.8.36 Considere o seguinte formulado:

$$
1250 \mathrm{~kg} / \mathrm{ha} \text { de } 4-30-10
$$

Esse formulado atende às exigências de uma cultura, quanto aos macronutrientes 
minerais essenciais às suas plantas?

Exigência da cultura: 50 kg de N; 360 kg de P2O5;120 kg de K2O.

Problema 4.8.37 Um agricultor vendeu 3/10 de sua produção de café com um lucro de $30 \%$ e a parte restante com prejuízo de $10 \%$. No total da operação, o agricultor obteve lucro ou prejuízo?

Problema 4.8.38 Se o aluguel consome 40\% do salário de um trabalhador e se seu salário sofrer um aumento de $180 \%$ e o aluguel sofrer um aumento de $250 \%$. O novo aluguel passa a representar qual porcentagem do novo salário?

Problema 4.8.39 Se, em um período em que os preços subiram 82\%, os salários de uma categoria aumentaram 30\%. Então, para que os salários recuperem o poder de compra, qual deve ser o aumento percentual?

Problema 4.8.40 Uma melancia de massa 10kg contém 99\% de água. Após deixá-la aberta algum tempo, um agricultor verificou que alguma água tinha evaporado deixando-a com 98\% de água. Após a evaporação, a nova massa da melancia, em quilogramas, é de?

Problema 4.8.41 Uma fábrica de laticínios comprou 2000 litros de leite puro. Para a produção de iogurte, foi retirado certo volume desse leite, substituído por água. Em seguida, retirou-se novamente o mesmo volume da mistura, que novamente foi substituída por água. Na mistura final existem 1125 litros de leite. O percentual do volume inicial de leite retirado, em relação ao volume total inicial, é?

Problema 4.8.42 Subtraindo 99\% de 19\% de 99, obtemos qual valor?

Problema 4.8.43 Se, em um produto de três números positivos, aumentarmos dois deles de $20 \%$ e diminuirmos o outro em $40 \%$, então qual será a alteração percentual desse produto?

Problema 4.8.44 Um agricultor vendeu um trator por $\mathrm{R} \$ 72$ 000,00, com $10 \%$ de desvalorização sobre o seu preço de compra. Portanto, o valor de compra, imediatamente anterior a essa venda, em reais, é?

Problema 4.8.45 Deseja-se balancear uma ração para frangos de corte na fase de retirada. As tabelas a seguir, mostram as exigências desses animais, e os alimentos disponíveis com suas respectivas composições. 
Tabela 4.8.1 - Exigências nutricionais para frangos de corte em fase de retirada

\begin{tabular}{ll}
\hline Nutrientes & Exigências \\
\hline Energia Metabolizável $(\mathrm{kcal} / \mathrm{kg})$ & 3200 \\
\hline Proteína (\%) & 17,24 \\
\hline
\end{tabular}

Tabela 4.8.2 - Composição química dos alimentos disponíveis

\begin{tabular}{lcr}
\hline Alimentos & EM (kcal/kg) & PB (\%) \\
\hline Milho Grão & 3340 & 8,26 \\
\hline Farelo de Soja & 3154 & 45,32 \\
\hline
\end{tabular}

Determine a quantidade de cada alimento, necessária para satisfazer a exigência de proteína bruta (PB) desses animais.

Problema 4.8.46 Calcule as porcentagens em que aveia e bagaço de soja, devem ser misturados, de modo a obter-se uma mistura com $20 \%$ de proteína bruta.

Teor proteico dos alimentos:

Aveia: $80 \mathrm{~g}$ de PB por kg;

Bagaço de Soja: $440 \mathrm{~g}$ de PB por kg.

Problema 4.8.47 Usando o Quadrado de Pearson, determine as porcentagens em que milho e farinha de peixe devem ser misturados, de modo, a obter-se uma mistura com $20 \%$ de proteína bruta.

Tabela 4.8.3 - Composição química dos alimentos disponíveis

\begin{tabular}{l|r}
\hline Alimento & PB (\%) \\
\hline Milho & 9 \\
\hline Farinha de Peixe & 53 \\
\hline
\end{tabular}

Problema 4.8.48 Determine a composição final de 100Kg de ração concentrada, com 18\% de proteína bruta e $80 \%$ de nutrientes digestíveis totais, utilizando o Quadrado de Pearson. Os teores de proteína dos ingredientes disponíveis, no caso, grão de milho moído e farelo de soja, são 9,8\% e 47,5\% de PB, respectivamente. 


\section{Primeiro Grau}

\subsection{Equação do Primeiro Grau}

Uma equação do primeiro grau é toda equação que pode ser escrita da forma:

$$
a X+b=0 ;
$$

em que a e b são constantes reais, com ał 0 , e X é a incógnita.

Exemplo 5.1.1 Resolva a equação de primeiro grau abaixo:

$$
3 X+6=0 .
$$

Resolução:

$$
\begin{aligned}
& 3 X+6-6=0-6 \\
& 3 X=-6 \\
& X=-\frac{6}{3} \\
& X=-2
\end{aligned}
$$

Portanto, a solução da equação é X = - 2 .

\subsection{Resolução de problemas envolvendo equação do pri- meiro grau relacionados à agropecuária}

A equação de primeiro grau é, uma importante ferramenta na resolução de situações -problemas de atividades agropecuárias tais como: determinar as quantidades necessárias de cada elemento para a elaboração de ração, distribuir mudas de hortaliças entre canteiros.

Exemplo 5.2.1 Distribua 3100 mudas de uma hortaliça qualquer, entre dois canteiros, de modo que, um canteiro tenha o dobro da quantidade de mudas do outro, acrescido de 100 mudas.

Resolução: Sejam X e Y as quantidades de mudas de cada canteiro.

$$
Y=2 X+100
$$


Como temos um total de 3100 mudas, segue que:

$$
\begin{gathered}
X+Y=3100 \\
X+2 X+100=3100
\end{gathered}
$$

Então, a equação de primeiro grau que expressa a situação-problema é dada por:

$$
3 X+100=3100
$$

Resolvendo a equação, obtemos:

$$
\begin{gathered}
3 X+100-100=3100-100 \\
3 X=3000 \\
X=1000 .
\end{gathered}
$$

Logo, um canteiro irá receber 1000 mudas e o outro 2100.

Exemplo 5.2.2 Na composição de 500kg de ração, calcule as quantidades de sorgo, milho, farelo de soja e farinha de carne, sabendo que: a quantidade de milho deverá ser $25 \mathrm{~kg}$ a mais do que o triplo da de sorgo; o farelo de soja, 1/4 do total do sorgo; e a farinha de carne, a terça parte do farelo de soja.

Resolução: Sejam X, Y, Z e W as quantidades de sorgo, milho, farelo de soja e farinha de carne, respectivamente. Então, temos que:

$$
\begin{aligned}
& Y=3 X+25 \\
& W=\frac{3 X}{4} \\
& Z=\frac{X}{4}
\end{aligned}
$$

Com efeito, a equação do primeiro grau que expressa a situação-problema é dada por:

$$
X+3 X+25+\frac{3 X}{4}+\frac{X}{4}=500
$$

Resolvendo a equação, obtemos:

$$
\begin{aligned}
& X+3 X+25+\frac{3 X}{4}+\frac{X}{4}=500 \\
& 4 X+12 X+100+3 X+X=2000 \\
& 20 X+100=2000 \\
& 20 X+100-100=2000-100 \\
& 20 X=1900 \\
& X=\frac{1900}{20} \\
& X=95
\end{aligned}
$$


Portanto, as quantidades são: $95 \mathrm{~kg}$ de sorgo, $310 \mathrm{~kg}$ de milho, $232,5 \mathrm{~kg}$ de farelo de soja e $77,5 \mathrm{~kg}$ de farinha de carne.

\subsection{Sistema de equações lineares do 10 grau com duas incógnitas e duas equações}

\subsubsection{Definição de um sistema linear $2 \times 2$}

Um sistema linear 2x2, é a combinação de duas equações lineares com duas incógnitas, escrito da forma:

$$
\left\{\begin{array}{l}
a_{1} X+b_{1} Y=c_{1} \\
a_{2} X+b_{2} Y=c_{2}
\end{array}\right.
$$

tal que a1, a2, b1, b2 são os coeficientes, X e Y são as incógnitas e c1, c2 são os termos independentes.

Se $\mathrm{c} 1=\mathrm{c} 2=0$, dizemos que o sistema é homogêneo. No caso de um sistema homogêneo, ele terá pelo menos uma solução, $X=0$ e Y $=0$. Essa solução é chamada de solução trivial.

Exemplo 5.3.1.1

$$
\left\{\begin{array}{l}
3 X+11 Y=4 \\
X-2 Y=16
\end{array}\right.
$$

É um sistema linear com 2 equações lineares e duas incógnitas.

\subsubsection{Solução de um sistema linear $2 \times 2$}

Resolver um sistema de equações lineares $2 \times 2$, significa, determinar os valores das incógnitas, que satisfazem, simultaneamente, as equações do sistema.

Um sistema linear 2x2 pode apresentar três formas de soluções:

- uma única solução;

- infinitas soluções;

- nenhuma solução. 


\subsubsection{Método da substituição}

Exemplo 5.3.2.1.1 Resolva o sistema

$$
\left\{\begin{array}{l}
3 X-Y=2 \\
4 X+5 Y=9
\end{array}\right.
$$

Resolução: Primeiro escolhemos de modo conveniente uma das equações, com o objevo de determinarmos o valor de uma das incógnitas.

$$
\begin{aligned}
& 3 X-Y=2 \\
& Y=3 X-2
\end{aligned}
$$

Dessa forma, o valor de $Y$ encontrado por meio da primeira equação é $Y=3 X-2$.

Em seguida devemos substituir o valor encontrado da incógnita $Y$, na outra equação.

$$
4 X+5(3 X-2)=9
$$

Resolvendo essa equação, obtemos:

$$
\begin{aligned}
& 4 X+5(3 X-2)=9 \\
& 4 X+15 X-10=9 \\
& 19 X-10=9 \\
& 19 X-10+10=9+10 \\
& 19 X=19 \\
& X=\frac{19}{19} \\
& X=1
\end{aligned}
$$

Substituindo o valor $\mathrm{X}=1$, obtemos:

$$
\begin{gathered}
3(1)-Y=2 \\
3-Y=2 \\
Y=1
\end{gathered}
$$

Portanto, a solução do sistema é dada por $\mathrm{X}=1$ e $\mathrm{Y}=1$.

\subsubsection{Método da eliminação}

Exemplo 5.3.2.2.1. Resolva o sistema

$$
\left\{\begin{array}{l}
3 X-Y=2 \\
4 X+5 Y=9
\end{array}\right.
$$


Resolução: Devemos multiplicar as equações, podendo ser apenas uma, por números tais que, somando as equações membro a membro, uma das incógnitas desapareça.

Para esse caso, vamos multiplicar a primeira equação por 4 e multiplicar a segunda equação por -3. Dessa forma, obtemos o seguinte sistema $2 \times 2$ equivalente:

$$
\left\{\begin{array}{l}
12 X-4 Y=8 \\
-12 X-15 Y=-27
\end{array}\right.
$$

Somando as equações membro a membro, obtemos:

$$
\begin{aligned}
& -19 Y=-19 \\
& Y=\frac{-19}{-19} \\
& Y=1
\end{aligned}
$$

Agora, substituindo o valor $\mathrm{Y}=1$ em qualquer uma das equações do sistema:

$$
\begin{aligned}
& 12 X-4(1)=8 \\
& 12 X-4=8 \\
& 12 X-4+4=8+4 \\
& 12 X=12 \\
& X=\frac{12}{12} \\
& X=1
\end{aligned}
$$

Portanto, a solução do sistema é $\mathrm{X}=1$ e $\mathrm{Y}=1$.

\subsection{Método algébrico aplicado no balanceamento de ra- ção com dois alimentos/ingredientes para o acerto de um nutriente}

O sistema de equações do 10 grau, assim como o Quadrado de Pearson, pode ser utilizado como um método para determinar a mistura dos alimentos no processo de fabricação de uma ração, fixado o percentual desejado de certo nutriente.

Exemplo 5.4.1 Utilizando um sistema de equações do 10 grau, determine o balanceamento de uma ração para suínos com $18 \%$ de proteína bruta (PB). Os alimentos disponíveis são o farelo de soja, com $45,32 \%$ de PB, e o milho com $8,26 \%$ de PB. 
Resolução: Para representarmos o sistema, devemos escrever suas informações descritivas na forma algébrica. $\mathrm{X}=\mathrm{kg}$ de farelo de soja, $\mathrm{Y}=\mathrm{kg}$ de milho.

Desse modo, obtemos o seguinte sistema:

$$
\left\{\begin{array}{l}
X+Y=100 \\
0,4532 X+0,0826 Y=18
\end{array}\right.
$$

Segue da primeira equação, que:

$$
X=100-Y
$$

Substituindo na segunda equação, obtemos:

$$
\begin{aligned}
& 0,4532(100-Y)+0,0826 Y=18 \\
& 45,32-45,32 Y+0,0826 Y=18 \\
& 0,3706 Y=27,32 \\
& Y=\frac{27,32}{0,3706} \\
& Y=73,71
\end{aligned}
$$

Substituindo na primeira equação, obtemos:

$$
\begin{gathered}
X=100-73,71 \\
X=26,28
\end{gathered}
$$

Portanto, as quantidades são: $73,71 \%$ de milho e $26,28 \%$ de farelo de soja.

\subsection{Problemas - Capítulo 5}

Problema 5.5.1 Resolva as equações a seguir:
(a) $2 \mathrm{X}+4=12$
(b) $2 \mathrm{X}-(\mathrm{X}-1)=\mathrm{X}+1$
(c) $3 \mathrm{X}-(\mathrm{X}-1)=2 \mathrm{X}+3$

Problema 5.5.2 Na composição de $1000 \mathrm{~kg}$ de ração, calcule as quantidades de sorgo, milho, farelo de soja e farinha de carne, sabendo que, a quantidade de milho deverá ser $50 \mathrm{~kg}$ a mais do que o dobro da de sorgo; o farelo de soja, $1 / 2$ do total de sorgo; e a farinha de carne, a terça parte do farelo de soja.

Problema 5.5.3 Jorge comprou duas caixas de morangos. Na primeira caixa, ele encontrou 1/4 dos morangos estragados. Na segunda caixa, ele observou que havia um mo- 
rango a mais no total, e que $1 / 5$ dos morangos estavam estragados. Se no total, 69 morangos estavam bons, quantos morangos, considerando as duas caixas, estavam estragados?

Problema 5.4.4 Anderson comprou certa quantidade de mudas de maracujá e vendeu cada uma por $R \$ 16,00$, lucrando um total de $R \$ 300$. Se Anderson tivesse vendido cada muda por $\mathrm{R} \$ 9,00$ teria tido um prejuízo de $\mathrm{R} \$ 5,00$. Qual é o valor que Anderson pagou por cada muda de maracujá?

Problema 5.5.5 Distribua 5100 mudas de uma hortaliça qualquer, entre dois canteiros, de modo que um canteiro tenha a dobro da quantidade de mudas do outro, acrescido de 100 mudas.

Problema 5.5.6 O preço de venda de um trator é tal que o lucro é 20\% deste preço. Aumentando-se o preço de $\mathrm{R} \$ 20$ 000,00, o lucro passa a ser um terço do novo preço de venda. Qual é o preço de venda do trator?

Problema 5.5.7 0 terreno de Juliana é retangular e tem 18 metros a menos de largura do que de comprimento. 0 perímetro do terreno é de 84 metros. Qual é o comprimento do terreno? E qual é a largura?

Problema 5.5.8 0 terreno de Paula tem a forma retangular, a largura mede $40 \%$ do comprimento, e o perímetro é de 42 metros. Qual é a área do terreno de Paula?

Problema 5.5.9 Utilizando um sistema de equações do 10 grau, determine o balanceamento de uma ração para suínos com $25 \%$ de proteína bruta (PB). Os alimentos disponíveis são o farelo de soja, com $45,32 \%$ de PB, e o milho, com 8,26\% de PB.

Problema 5.5.10 Utilizando um sistema de equações do 10 grau, determine as porcentagens de milho, com teor proteico de (90g de PB) $/ \mathrm{kg}$, e de farinha de peixe, com teor proteico de (530g de $\mathrm{PB}) / \mathrm{kg}$, de modo, a obter uma ração balanceada, com (180g de PB)/ $\mathrm{kg}$. 


\section{Matemática Financeira Aplicada à Agroeconomia}

De acordo com a assessoria estratégica do Ministério da Agricultura, a renda no campo atingiu em 2015 um total de 492,5 bilhões de reais. O destaque nesse resultado foi a soja, responsável por 37\% de toda a renda do campo. Em 2015 o agronegócio brasileiro representou 45,9\% da balança comercial brasileira.

A prosperidade de uma propriedade rural está muito relacionada com seu envolvimento com o setor de negócios e com sua capacidade de aproveitar o máximo de seus recursos. Diante disso, conhecer pequenas lições sobre matemática financeira é fundamental para o pleno exercício das atividades de economia e administração rural. Por meio delas, é possível tomar decisões financeiras racionais nos momentos de: aquisição de empréstimos; escolha de investimentos; decisão entre uma compra à vista com desconto ou parcelada; cálculo da viabilidade financeira de um investimento.

Dessa forma, o produtor de hoje precisa estar bem informado e melhor capacitado para gerenciar os riscos e adversidades operacionais em sua propriedade.

\subsection{Depreciação}

Depreciação é a perda de valor dos bens físicos, tais como, imóveis, automóveis e máquinas, através do uso. Com o propósito de substituir um determinado bem ao final de sua vida útil, uma empresa reserva uma parte de sua receita anual em um fundo, chamado fundo de depreciação; os depósitos anuais no fundo de depreciação são chamados de quotas de depreciação. Em qualquer tempo, a diferença entre o valor original do bem e a soma do fundo de depreciação chama-se valor contábil. No final de sua vida útil, o valor contábil deve ser o seu valor residual. o método mais simples de depreciar um bem é chamado de método das médias. Esse método utiliza depósitos anuais iguais, ao longo da vida útil do bem, no fundo de depreciação.

Exemplo 6.1.1 Mirando o crescimento de sua produção, um pecuarista irá adquirir uma forrageira com maior transferência de força e mais econômica. Sabendo que a nova forrageira custa $R \$ 55000,00$, e que tem vida útil de 6 anos, ao $\mathrm{m}$ dos quais, possui um valor residual de $\mathrm{R} \$ 5$ 500,00.

(a) Calcule a depreciação média anual.

(b) Faça um quadro de depreciação indicando o valor contábil ao m de cada cano. 


\section{Resolução:}

(a) Depreciação total = (Custo)-(Valor residual)

Depreciação total $=55000-5500=49500$

Logo, a depreciação média anual é dada por:

$$
49500 \div 6=8250
$$

(b) Tendo em vista que a quota anual de depreciação é de $\mathrm{R} \$ 8$ 250,00, o fundo de depreciação aumenta esse valor a cada ano, e o valor contábil da forrageira diminui desse valor cada ano.

\begin{tabular}{lccr}
\hline Anos & Quota & Fundo & Valor contábil \\
\hline 0 & 0 & 0 & 55000 \\
\hline 1 & 8250 & 8250 & 46750 \\
\hline 2 & 8250 & 16500 & 38500 \\
\hline 3 & 8250 & 24750 & 30250 \\
\hline 4 & 8250 & 33000 & 22000 \\
\hline 5 & 8250 & 41250 & 13750 \\
\hline 6 & 8250 & 50000 & 5500 \\
\hline
\end{tabular}

Quando se trata de máquinas, também é conveniente basear o valor da quota de depreciação anual no número de horas trabalhadas pela máquina ou no número de peças produzidas durante o ano.

Exemplo 6.1.2 Um pulverizador, que custa $R \$ 50$ 000,00, tem um valor residual estimado de R\$15 000,00 e uma vida útil de 70000 horas de operação.

(a) Calcule a quota de depreciação por hora de operação.

(b) Faça um quadro indicando o valor contábil para cada um dos 4 primeiros anos de operação da máquina, durante os quais as horas de operação foram respectivamente: 4000, 5 000, 6000 e 8500 .

\section{Resolução:}

(a) Depreciação total $=$ (Custo) $-($ Valor residual $)$

$$
=50000-15000=35000
$$

Logo, a depreciação por hora de operação é dada por:

$$
35000 \div 70000=0,5
$$


(b)

\begin{tabular}{lcccr}
\hline Anos & Horas & Quota & Fundo & Valor contábil \\
\hline 0 & 0 & 0 & 0 & 50000 \\
\hline 1 & 4000 & 2000 & 2000 & 48000 \\
\hline 2 & 5000 & 2500 & 4500 & 45500 \\
\hline 3 & 6000 & 3000 & 7500 & 42500 \\
\hline 4 & 8500 & 4250 & 11750 & 38250 \\
\hline
\end{tabular}

\subsection{Matemática Financeira}

O princípio básico da matemática financeira é a realização de empréstimo. Empréstimo é a forma pela qual, uma pessoa (física ou jurídica), transfere a outra pessoa a posse de uma determinada quantia $C$, chamada de capital, por certo período de tempo. Após o término desse período, recebe o capital C de volta, acrescido de um valor J, chamado de juros.

O valor final M dessa operação é chamado de montante.

$$
\mathrm{M}=\mathrm{C}+\mathrm{J}
$$

A taxa de crescimento i do capital é denominada taxa de juros.

Exemplo 6.2.1 Um agricultor tomou um empréstimo de $\mathrm{R} \$ 100$ 000,00. Três anos depois, pagou $\mathrm{R} \$ 110000,00$. Com efeito, os juros pagos pelo agricultor, ao final do empréstimo, são de $R \$ 10000,00$, e a taxa de juros é de $10 \%$ ao trimestre. Dessa forma, o montante final dessa operação foi de $\mathrm{R} \$ 110000,00$.

\subsubsection{Equívocos em raciocínios financeiros}

É comum encontrarmos pessoas acreditando que $R \$ 110,00$ valem mais que $R \$ 100,00$. Esse entendimento está correto, desde que, os valores se refiram a uma mesma data. Pois, se referirem a datas distintas, $R \$ 110,00$ podem ter o mesmo valor que $R \$ 100,00$, ou até mesmo um valor inferior. Muito disso deve-se à inflação, fenômeno financeiro atribuído ao aumento do nível dos preços de serviços e mercadorias. Outro erro encontrado com frequência, é a soma de quantias referidas a datas distintas. Não é necessariamente ver- 
dade que comprar em 4 prestações de $\mathrm{R} \$ 100,00$ seja mais econômico que comprar em 4 vezes de $\mathrm{R} \$ 150,00$.

\subsubsection{Cálculo de juros em financiamentos agropecuários}

O financiamento agropecuário é uma operação financeira essencial para o desenvolvimento do agronegócio brasileiro. Por meio dele, produtores rurais podem adquirir maquinários agrícolas, ração, adubos, sementes, dentre outros. Essas operações financeiras também permitem ao produtor, financiar a construção de silos, galpões, fábricas. Para termos uma ideia da importância dessa modalidade de crédito, em 2015, a feira de tecnologia agrícola Show Rural, realizada entre os dias $1^{\circ}$ e 5 de fevereiro, em Cascavel, no oeste do Paraná, prospectou negócios acima de R\$ 2 bilhões.

\section{Exemplo 6.2.2.1}

\begin{tabular}{c|c|c|c}
\hline Cultura & Valor & Taxa de Juros & Prazo \\
\hline Café & $\mathrm{R} \$ 36000,00$ & 3\% a.a. & 2 anos \\
\hline
\end{tabular}

Analise a tabela de custeio de projeto apresentada acima. Os juros $\mathrm{J}_{1}$ ao final do primeiro ano são calculados da forma:

$$
\mathrm{J}_{1}=36000 \times 0,03 \times 1=1080
$$

Logo, o montante $\mathrm{M}_{1}$ ao final do primeiro ano é:

$$
M_{1}=36000+1080=R \$ 37080,00
$$

Calculando os juros $\mathrm{J}_{2}$, de forma acumulada, ao final do segundo ano obtemos:

$$
\mathrm{J}_{2}=37080 \times 0,03 \times 1=1112,40
$$

Logo, o montante acumulado $\mathrm{M}_{2}$ ao final do segundo ano é:

$$
M_{2}=37080+1112,40=R \$ 38192,40
$$

Desse modo, o montante final a ser pago pelo produtor por essa operação de empréstimo é $\mathrm{R} \$ 38$ 192,40.

Exemplo 6.2.2.2 A produção de carne de frango, subiu 3,5\% em 2015 e deve aumentar entre 3\% e 5\% em 2016, impulsionada pelas exportações.[...]

Na ponta do lápis, o consumo interno aumentou de 42,9 quilos por habitante ao ano 
para 44 quilos.

Fonte: CRESCIMENTO de até 5\%. Revista GloboRural, n363,p.44, jan 2016.

Observando essa demanda muito forte, um produtor de frangos de corte, decidiu tomar um empréstimo para modernizar seu galpão. 0 empréstimo realizado foi no valor de $\mathrm{R} \$ 20$ 000,00, à taxa de juros de 5\% a.a., com prazo de 3 anos. Qual será o montante final pago por esse produtor?

Resolução: Os juros $\mathrm{J}_{1}$ ao final do primeiro ano são calculados da forma:

$$
J_{1}=20000 \times 0,05 \times 1=1000
$$

Então, ao final do primeiro ano o montante $\mathrm{M}_{1}$ é dado por:

$$
M_{1}=20000+1000=R \$ 21000,00 .
$$

No final do segundo ano, os juros acumulados J2 são:

$$
\mathrm{J}_{2}=21000 \times 0,05 \times 1=1050
$$

Desse modo, o montante $\mathrm{M}_{2}$ é:

$$
M_{2}=21000+1050=R \$ 22050,00 .
$$

Por m, os juros acumulados ao final do terceiro ano J3, são:

$$
\mathrm{J}_{3}=22050 \times 0,05 \times 1=1102,50 .
$$

Então, o montante $\mathrm{M}_{3}$ é dado por:

$$
M_{3}=22050+1102,50=R \$ 23152,50 .
$$

Teorema 6.1 No sistema de juros compostos com taxa de juros i, um capital inicial C transforma-se, em $n$ períodos de tempos, em um montante M igual a:

$$
M=C(1+i)^{n}
$$

Demonstração: Para cada valor de $\mathrm{k}$, considere $\mathrm{C}_{\mathrm{k}}$ a dívida após k períodos de tempo. Dessa forma, obtemos:

$$
\mathrm{C}_{\mathrm{k}+1}=\mathrm{C}_{\mathrm{k}}+\mathrm{i} \mathrm{C}_{\mathrm{k}}=(1+\mathrm{i}) \mathrm{C}_{\mathrm{k}}
$$

Daí segue que $C_{k}$ é uma progressão geométrica de razão $1+i$ tal que

$$
C_{n}=C_{0}(1+i)^{n}
$$

Exemplo 6.2.2.3 Depois de fechar 2015 com U\$ 750 milhões em exportações um 
crescimento de $25 \%$ em relação a 2014, os produtores brasileiros de frutas frescas esperam ampliar seus negócios no mercado externo este ano para U\$\$ 850 milhões e chegar à marca de U\$\$ 1 bilhão até 2018.

Fonte: MELÃO para o mundo. Revista GloboRural, n.364, p.39, fev. 2016.

De olho nesse mercado, um fruticultor decidiu tomar um empréstimo para investir na aquisição de máquinas agrícolas, no valor de $\mathrm{R} \$ 200$ 000,00, à taxa de juros de $6 \%$ a.a., com prazo de 4 anos. Calcule o montante final dessa operação.

\section{Resolução:}

Dados:

$$
\begin{gathered}
\mathrm{C}_{0}=200000 \mathrm{i}=0,06 \\
\mathrm{n}=4
\end{gathered}
$$

Então,

$$
\begin{gathered}
C 4=200000(1+0,06) 4 \\
C 4=252495,39
\end{gathered}
$$

Portanto, o montante final dessa operação de crédito é de $\mathrm{R} \$ 252$ 495,39.

\subsubsection{Taxas proporcionais não representam taxas equivalentes}

Um erro muito comum cometido pelas pessoas, referente às operações financeiras, é achar que uma taxa de $20 \%$ ao mês é equivalente a uma taxa de $60 \%$ ao trimestre. $\mathrm{Na}$ verdade, as taxas de $20 \%$ ao mês e $60 \%$ ao trimestre são taxas proporcionais, mas não equivalentes.

Teorema 6.2 Se a taxa de juros relativamente a um determinado período de tempo é igual a i, a taxa de juros relativamente a n períodos de tempo é I tal que $1+\mathrm{I}=(1+\mathrm{i}) n$.

Exemplo 6.2.3.1 Investindo um capital a juros de $2 \%$ ao ano com capitalização mensal. Qual é a verdadeira taxa anual de juros está sendo aplicada ao capital?

\section{Resolução:}

$$
\begin{gathered}
1+\mathrm{I}=(1+0,02) 12 \\
1+\mathrm{I}=1,26 \\
\mathrm{I}=1,26-1=0,26
\end{gathered}
$$

Portanto, uma taxa mensal de juros de $2 \%$ equivale a uma taxa anual de juros de $26 \%$. 
A taxa de $2 \%$ a.m. é chamada de taxa nominal e a taxa equivalente de $26 \%$ a.a. é chamada de taxa efetiva.

Exemplo 6.2.3.1 Um produtor rural tomou um empréstimo de $\mathrm{R} \$ 300,00$ a juros mensais de 5\%. Dois meses após, ele pagou R $\$ 150,00$. Um mês após esse pagamento, liquidou a dívida. Qual o valor desse último pagamento?

Resolução: Os esquemas de pagamento a seguir são equivalentes:
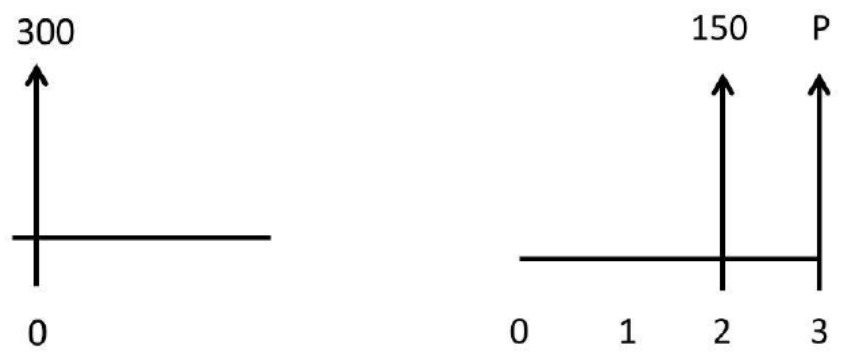

Tomando os valores em uma mesma data, obtemos:

$$
300 \times 1,052=300 \times 1,1025=330,75 .
$$

Descontando a prestação paga, obtemos:

$$
330,75-150=180,75 .
$$

Agora, aplicando $5 \%$ de juros, obtemos:

$$
180,75 \times 1,05=189,79
$$

Portanto, $\mathrm{P}=189,79$.

Teorema 6.3 $\mathrm{O}$ valor de uma série de $\mathrm{n}$ parcelas iguais à quantia $\mathrm{P}$, uma unidade de tempo anterior ao primeiro pagamento, tal que i é a taxa de juros, é dada por:

$$
A=P \frac{1-(1+i)^{-n}}{i}
$$

\section{Demonstração:}

$$
A=P(1+i)^{-1}+P(1+i)^{-2}+\cdots+P(1+i)^{-n}
$$

Dessa forma, obtemos:

$$
A=P(1+i)^{-1} \frac{1-(1+i)^{-n}}{1-(1+i)^{-1}}=P \frac{1-(1+i)^{-n}}{i}
$$

Exemplo 6.2.3.2 Um produtor rural deseja comprar um trator cujo preço à vista é 
$\mathrm{R} \$ 120$ 000,00. Para isso, ele irá financiar esse valor em 80 prestações mensais, a primeira sendo paga em um mês após a compra. Sabendo que os juros da linha de crédito são de 0,5\% ao mês, determine o valor das prestações.

\section{Resolução:}

$$
120000=P \frac{1-(1+0,05)^{-80}}{0,005}
$$

Resolvendo obtemos:

$$
\begin{aligned}
& 120000=P \frac{1-0,67}{0,005}=\frac{0,33}{0,005} \\
& 120000=66 P \Rightarrow P=1818,18
\end{aligned}
$$

\subsection{Problemas - Capítulo 6}

Problema 6.3.1 Visando o crescimento de sua produção, um agricultor irá adquirir um trator com maior eficiência. Sabendo que esse novo equipamento custa $R \$ 250000,00$, e que tem vida útil de 10 anos, ao mês dos quais possui um valor residual de $\mathrm{R} \$ 50$ 000,00.

(a) Calcule a depreciação média anual.

(b) Faça uma tabela de depreciação indicando o valor contábil ao mês de cada ano.

Problema 6.3.2 Um pulverizador que custa $\mathrm{R} \$ 80$ 000,00 tem um valor residual estimado de R 20 000,00 e uma vida útil de 60000 horas de operação.

(a) Calcule a quota de depreciação por hora de operação.

(b) Faça uma tabela indicando o valor contábil para cada um dos 4 primeiros anos de operação da máquina, durante os quais as horas de operação foram respectivamente: 6000,7 000, 8000 e 10000 .

Problema 6.3.3 Para aumentar sua renda, um produtor de pimenta decidiu investir na compra de um secador rotativo para pimenta e um debulhador de pimenta. O secador custa $R \$ 9000,00$, tem um valor residual de $R \$ 3000,00$ e possui uma vida útil de 6 anos. O debulhador custa 18 000,00, tem um valor residual de $\mathrm{R} \$ 6000,00$ e uma vida útil de 10 anos.

(a) Calcule a depreciação média anual do secador rotativo de pimenta. 
(b) Calcule a depreciação média anual do debulhador de pimenta.

(c) Elabore um quadro indicando o valor contábil de cada ano de uso do secador rotativo de pimenta.

(d) Elabore um quadro indicando o valor contábil de cada ano de uso do debulhador de pimenta.

Problema 6.3.4 Uma máquina que custa $R \$ 3000,00$, tem uma vida útil estimada de 20000 horas de operação e um valor residual de $R \$ 600,00$. As horas de uso para os primeiros 5 anos foram: 1 800, 2 200, 2 000, 2500 e 2 400. Elabore um quadro indicando o valor contábil no fim de cada ano de uso.

Problema 6.3.5 Uma semeadora que custa $\mathrm{R} \$ 48$ 000,00 tem uma vida útil de 4 anos. Sabendo que seu valor residual é $\mathrm{R} \$ 12000,00$. Calcule a depreciação média anual.

Problema 6.3.6 Visando aumentar a produtividade, um agricultor deseja adquirir um trator agrícola no valor de $\mathrm{R} \$ 70000,00$. Sabendo que esse equipamento tem vida útil de 12 anos e seu valor residual é de $\mathrm{R} \$ 10$ 000,00. Elabore um quadro indicando o valor contábil de cada ano de uso.

Problema 6.3.7 Determine as taxas efetivas anuais equivalentes a:

(a) $20 \%$ a.a., com capitalização mensal.

(b) $20 \%$ a.a., com capitalização bimestral.

\section{Problema 6.3.8}

\begin{tabular}{c|c|c|c}
\hline Cultura & Valor & Taxa de Juros & Prazo \\
\hline Cacau & $\mathrm{R} \$ 96.000,00$ & $8 \%$ a.a. & 3 anos \\
\hline
\end{tabular}

Analise a tabela de custeio de projeto apresentada acima. Calcule o valor total do financiamento.

Problema 6.3.9 A indústria da carne e os confinados de gado querem o Brasil na cota 481, uma reserva europeia para produtos Premium.

Fonte: AGORA vai? Revista Dinheiro Rural. n.133, p. 19, fev. 2016.

Mirando essa oportunidade, um produtor de carne bovina, decidiu investir na sua propriedade, tomando um empréstimo no valor de $\mathrm{R} \$ 400.000,00$, à taxa de juros de $6 \%$ a.a., com prazo de 12 anos. Qual será o montante final pago por esse produtor? 
Problema 6.3.10 Um investimento a juros mensais de 5\% tem seu valor inicial dobrado em quanto tempo?

Problema 6.3.11 Uma loja oferece duas formas de pagamento:

- À vista com $5 \%$ de desconto.

- Em duas parcelas mensais iguais, sem desconto, sendo a primeira paga no ato da compra.

Sabendo que o dinheiro vale 3\% a.m. Qual é a opção mais vantajosa?

Problema 6.3.12 Calcular o montante de:

(a) R\$ 7000,00 por 6 anos à taxa de juros de 4\% capitalizados mensalmente.

(b) $\mathrm{R} \$ 200000,00$ por 10 anos à taxa de juros de $2 \%$ capitalizados trimestralmente.

Problema 6.3.13 Uma colhedeira de grãos custa $\mathrm{R} \$ 300$ 000,00 à vista e pode ser paga em 36 prestações mensais iguais. Se são cobrados juros de 0,8\% a.m., calcule o valor da prestação, supondo a primeira um mês após a compra. 


\section{Função Polinomial do Primeiro Grau}

\subsection{Noções Básicas sobre Função}

A formulação de uma função utilizando linguagem matemática é uma importante ferramenta para a ciência e, em especial, para a matemática aplicada. Por meio de funções é possível modelar fenômenos de diversos tipos como físicos, biológicos, sociais e químicos.

De maneira bem simples, podemos definir uma função como sendo uma descrição do comportamento observado na relação entre duas grandezas variáveis. Essa descrição é, feita com linguagem matemática apropriada.

Exemplo 7.1.1 Em um plantio de soja, uma colheitadeira mantém velocidade constante de $5 \mathrm{~km} / \mathrm{h}$.

(a) Complete o quadro abaixo, que relaciona o tempo $t$ (em horas) e a distância d (em quilômetros) percorrida nesse tempo.

\begin{tabular}{|l|l|l|l|l|}
\hline Tempo (t) & 0,5 & 1 & 2 & 2,5 \\
\hline Distância (d) & 2,5 & & & \\
\hline
\end{tabular}

(b) Que grandeza foi calculada em função da outra?

(c) Qual é a variável dependente?

(d) Escreva com linguagem matemática a lei dessa função que descreve d em função de $t$.

\section{Resolução:}

(a)

\begin{tabular}{|l|c|c|c|c|}
\hline Tempo (t) & 0,5 & 1 & 2 & 2,5 \\
\hline Distância (d) & 2,5 & 5 & 10 & 12,5 \\
\hline
\end{tabular}

(b) A distância percorrida $\mathrm{d}$ foi calculada em função do tempo t, pois a distância depende do tempo.

(c) A distância percorrida $\mathrm{d}$.

(d) $d=5 t$. 
Exemplo 7.1.2 O quadro a seguir relaciona a medida do lado (l) de um quadrado com sua área (S).

\begin{tabular}{|c|c|c|c|}
\hline Lado $(\mathrm{cm})$ & 1 & 2 & 3 \\
\hline Área $\left(\mathrm{cm}^{2}\right)$ & 1 & 4 & 9 \\
\hline
\end{tabular}

Examine os dados acima e responda os itens a seguir.

(a) Escreva em linguagem matemática a fórmula que descreve a área S de um quadrado em função da medida do lado 1.

(b) A área de um quadrado varia de modo diretamente proporcional à medida de seu lado?

\section{Resolução:}

(a) $\mathrm{S}=1^{2}$.

(b) Não, porque, quando duplicamos a medida do lado do quadrado, sua área não duplica.

\subsection{Definiçãa de uma função}

Dados dois conjuntos não vazios A e B, definimos uma função de A em B associando uma regra tal que cada elemento de A está em correspondência a um único elemento do conjunto B.

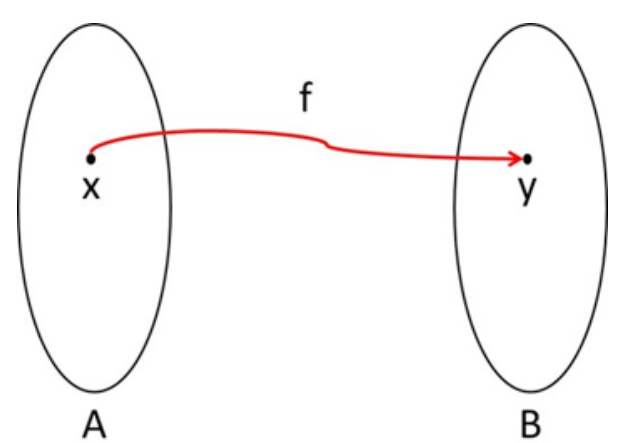

O conjunto A é chamado de Domínio, o conjunto B é chamado de Contradomínio, e cada elemento do conjunto B que está em correspondência com os elementos do conjunto A é chamado de elemento imagem. O conjunto formado por todos os elementos imagens e chamado de Imagem. 


\subsection{Gráfico de uma função}

O gráfico de uma função é uma representação visual muito importante para a análise de características ou comportamentos da relação entre grandezas estudada.

Exemplo 7.3.1 O gráfico abaixo mostra o registro da produção de maracujá, em lavoura permanente, no ES, no período de 1999 e 2000.

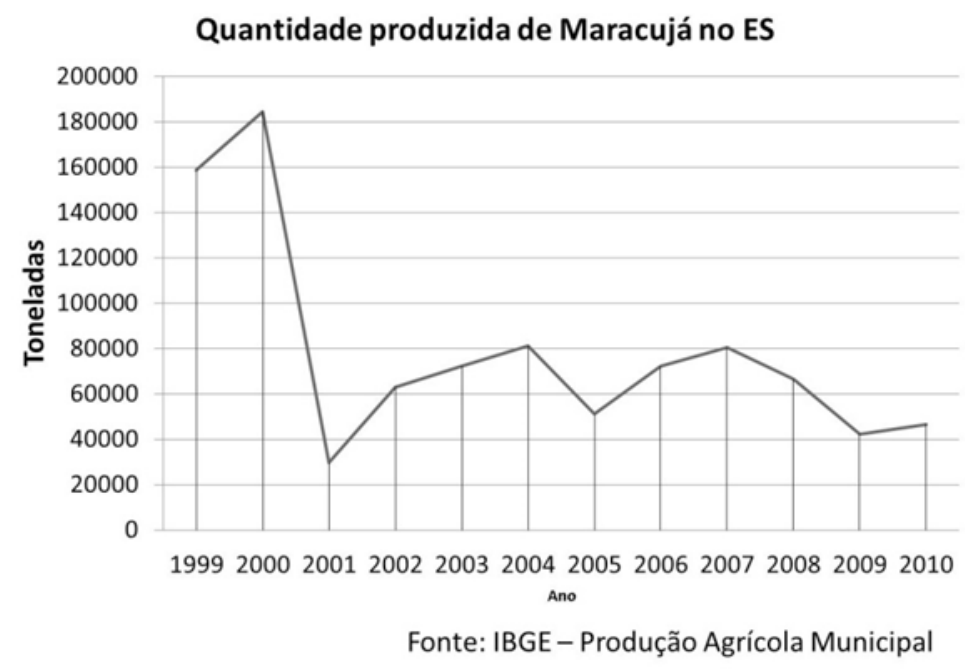

A figura acima representa um gráfico de linhas. Os pontos de um gráfico de linhas podem ser ligados por linhas que são segmentos de reta. Por isso, também, o nome de gráfico de segmento.

Analisando o gráfico, notamos uma variação acentuada na produção de maracujá. Com relação a esses dados, responda:

(a) Qual era a produção de maracujá aproximada no ano de 2000 no Espírito Santo?

(b) Qual era a produção de maracujá aproximada no ano de 2009 no Espírito Santo?

(c) Qual foi a variação da produção de maracujá aproximada no Espírito Santo no período de 2000 a 2009 ?

\section{Resolução:}
(a) 180000 toneladas.
(b) 40000 toneladas.
(c) $180000-40000=140000$ toneladas. 


\subsection{Função Afim}

Uma função $y=f(X)$ é chamada de função afim quando sua lei de formação é dada por:

$$
f(x)=a X+b
$$

tal que $a, b$ são números reais, sendo $a \neq 0$.

Exemplo 7.4.1 A área foliar é um importante parâmetro para estimar a produtividade das culturas agrícolas, pois está diretamente relacionada com atividades fotossintéticas e de transpiração das plantas. Para determinar a área foliar das plantas, são utilizadas relações alométricas de suas folhas. Na literatura, comumente encontramos como relação alométrica mais adequada o produto entre o comprimento (C) e largura (L) da folha, isto é, C x L.

O quadro a seguir mostra as medidas do comprimento (C) e da largura (L) de 5 folhas de abacaxi:

\begin{tabular}{c|c|c}
\hline Planta & $\mathrm{C}(\mathbf{c m})$ & $\mathrm{L}(\mathbf{c m})$ \\
\hline $\mathrm{ABCX} 1$ & 54,5 & 6 \\
\hline $\mathrm{ABCX} 2$ & 55 & 6,1 \\
\hline $\mathrm{ABCX} 3$ & 56 & 6,1 \\
\hline $\mathrm{ABCX} 4$ & 57 & 6,2 \\
\hline $\mathrm{ABCX} 5$ & 58 & 6,3 \\
\hline
\end{tabular}

Segundo FRANCISCO et al. (2014), a área foliar S, em cm2, do abacaxi é dada pela função

$$
S=f(x)=19,3 x-560
$$

tal que x é o produto entre o comprimento (C) e a largura (L). Desse modo, qual é a área foliar de cada uma das amostras?

\section{Resolução:}

\begin{tabular}{c|c|c|c}
\hline Planta & $\mathbf{x}$ & $\mathbf{f}(\mathbf{x})$ & $\mathbf{s}(\mathbf{c m} 2)$ \\
\hline$A B C X 1$ & 327 & $19,3 \times 327-560$ & 5751,1 \\
\hline$A B C X 2$ & 335,5 & $19,3 \times 35 ; 5-560$ & 5915,1 \\
\hline ABCX 3 & 341,6 & $19,3 \times 341,6-560$ & 6032,8 \\
\hline ABCX 4 & 353,4 & $19,3 \times 353,4-560$ & 6260,2 \\
\hline ABCX 5 & 365,4 & $19,3 \times 365,4-560$ & 6492,2 \\
\hline
\end{tabular}


O gráfico da função $f(x)=19,3 x-560$ é dado por:

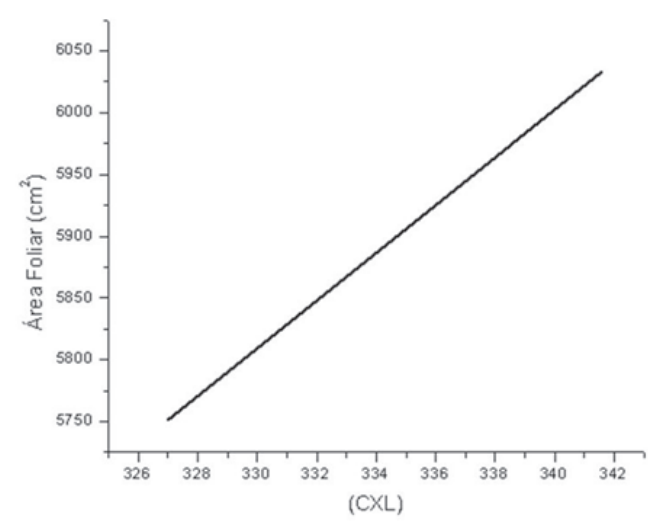

Exemplo 7.4.2 O mamão é um fruto de relevância nutricional e econômica. No entanto, ele possui uma validade limitada, em decorrência da deterioração e do rápido amadurecimento pós-colheita. Para amenizar esses efeitos indesejáveis do pós-colheita, pode-se aplicar uma solução de quitosana associada ao glicerol, promovendo, dessa forma, um prolongamento de sua vida útil. Estudos apontam que a vida útil do mamão pode ser obtida em função da concentração de quitosana pela função:

$$
y=3,74 X+8,35
$$

tal que x representa a concentração de quitosana em porcentagem e y a vida útil do mamão em dias. De acordo com essa função, qual é a vida útil do mamão recoberto com uma solução cuja concentração de quitosana é de $1 \%$ ?

Resolução: Fazendo X = 1, obtemos:

$$
y=3,74(1)+8,35=3,74+8,35=12,09
$$

Logo, com esse tratamento o mamão terá uma vida útil de 12 dias.

O gráfico a seguir, mostra essa relação.

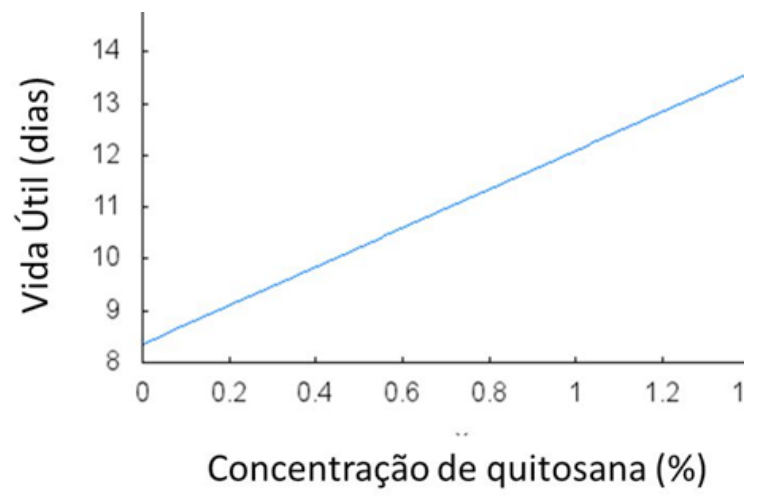




\subsection{Zero da Função Afim}

Considere a função afim $\mathrm{f}(\mathrm{x})=\mathrm{aX}+\mathrm{b}$. Zero da função afim $\mathrm{f}(\mathrm{X})$ é o valor assumido pela variável $X$ tal que $f(X)=0$.

Exemplo 7.5.1 Dada a função afim $\mathrm{f}(\mathrm{x})=3 \mathrm{X}+5$, determine o valor do zero dessa função.

Resolução:

$$
\begin{aligned}
& 3 X+5=0 \\
& 3 X+5-5=0-5 \\
& 3 X=-5 \\
& X=-\frac{5}{3}
\end{aligned}
$$

Logo, o valor do zero da função $f(X)=3 X+5$ é $X=-\frac{5}{3}$.

\subsection{Construindo o gráfico de uma função afim}

Toda função afim $f(\mathrm{X})=\mathrm{aX}+\mathrm{b}$ com $\mathrm{a} \neq 0$, tem como gráfico uma reta inclinada, não vertical e não paralela ao eixo OX. O gráfico de uma função afim é suficientemente determinado por dois pontos: o ponto de intersecção com o eixo OX dado pelo zero da função e o ponto de intersecção com o eixo OY dado pelo valor do coeficiente b.

Exemplo 7.5.1 Dada a função afim $y=2 x+6$, esboce seu gráfico.

Resolução: Inicialmente, vamos calcular o zero da função.

$$
\begin{aligned}
& 2 X+6=0 \\
& 2 X+6-6=0-6 \\
& 2 X=-6 \\
& \frac{2 X}{2}=-\frac{6}{2} \\
& X=-3
\end{aligned}
$$

Portanto, o gráfico dessa função intersecta o eixo OX no ponto $(-3,0)$.

Agora, vamos determinar o ponto de intersecção com o eixo OY. Note que, o coeficiente $b$ da função é 6 . Logo, a reta intersecta o eixo OY no ponto $(0,6)$. 


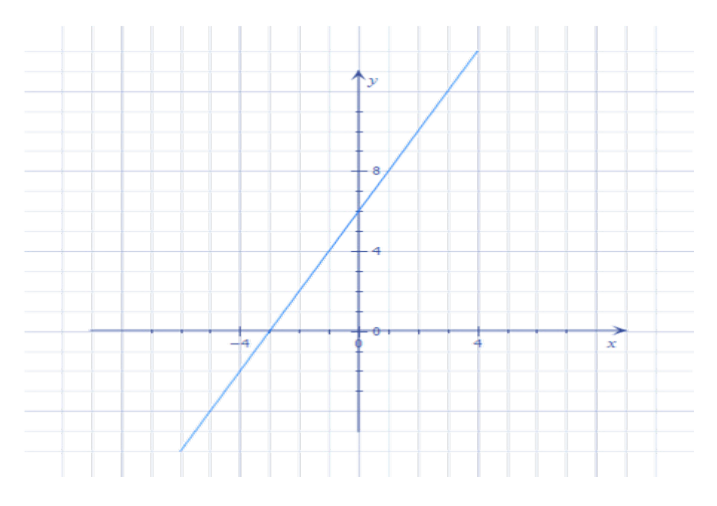

\subsection{Função Linear}

Uma função afim $y=f(X)$ é chamada de função linear quando sua lei de formação é dada por:

$$
y=a X, \text { com } a \neq 0
$$

Em outras palavras, uma função linear é, em particular, um caso especial da função afim.

Exemplo 7.7.1 Beto é um pequeno produtor de alface e possui uma horta quadrada com 8 metros cada lado. Visando aumentar sua produção, ele deseja fazer uma análise de quanto irá gastar para cercar o perímetro de sua horta, e para isso precisa determinar o perímetro da cerca em função da medida do lado. No quadro abaixo, temos o perímetro da horta dado em função da medida do lado.

\begin{tabular}{c|l|l|l|l}
\hline $\begin{array}{c}\text { Medida do lado } \\
(\mathbf{m})\end{array}$ & 8 & 9 & 10 & 12 \\
\hline $\begin{array}{c}\text { Medida do } \\
\text { perímetro (m) }\end{array}$ & 32 & 36 & 40 & 48 \\
\hline
\end{tabular}

Dessa forma, a função linear que associa a medida do lado (x) com o perímetro da horta (y) é dada por:

$$
\mathrm{y}=4 \mathrm{X}
$$

Sendo assim, se Beto decidir construir uma horta quadrada com lado medindo 15 metros. Quantos metros de cerca ele irá precisar instalar?

Resolução: Nesse caso basta calcularmos o valor de y para $\mathrm{x}=15$.

$$
y=4 .(15)=60
$$


Portanto, ele precisará de 60 metros de cerca.

Essa situação-problema nos mostra uma função na qual os valores de $\mathrm{x}$ (medida do lado do quadrado) e os correspondentes y (medida do perímetro) são diretamente proporcionais.

De modo geral, as funções lineares $\mathrm{y}=\mathrm{aX}$, com $\mathrm{a} \neq 0$, representam situações de proporcionalidade entre as variáveis (x) e (y). Em particular, seus gráficos são retas inclinadas (não verticais e não paralelas ao eixo $\mathrm{X}$ ) que passam pela origem, isto é, têm como zero da função sempre o valor de $\mathrm{x}=0$.

\subsection{Problemas - Capítulo 7}

Problema 7.8.1 Em um reservatório, havia 500 litros de água quando foi aberta uma torneira que despeja dentro dele 20 litros de água por minuto.

(a) Escreva a lei da função afim que relaciona a quantidade de água (y) no reservatório em função do número (x) de minutos em que a torneira fica aberta. (b) Quantos litros de água haverá no reservatório após a torneira ter sido aberta por 10 minutos?

Problema 7.8.2 A produção de porcos em uma pequena fazenda tem um custo fixo mensal de $\mathrm{R} \$ 2000,00$ e um custo variável de $\mathrm{R} \$ 90,00$ para cada animal. Considerando (x) o número de porcos. Responda:

(a) Qual a lei da função afim que fornece o custo total (y) da produção de porcos dessa fazenda em função do número (x) de animais?

(b) Calcule o custo de produção de 60 porcos.

(c) Determine o preço de venda de 60 porcos sabendo que o produtor vende cada porco com um lucro de $40 \%$.

Problema 7.8.3 Esboce o gráfico das funções:
(a) $y=X+1$
(b) $y=3 X-6$
(c) $y=-2 X+5$

Problema 7.8.4 0 crescimento das plantas pode sofrer influência da matéria orgânica e do ambiente. Em particular, a água salina pode ter grande importância nesse processo. Sabe-se que uma determinada planta Alpha possui sua altura (y), em centímetros, em função da salinidade da água ( $\mathrm{x}$ ), em dSm-1, dada pela função afim $\mathrm{y}=-2,04 \mathrm{X}+40,2$. Nessas condições, responda: 
(a) Qual é a altura da planta Alpha para a salinidade da água em 4dSm-1?

(b) 0 que ocorre com a altura da planta com o aumento da salinidade da água?

(c) Esboce o gráfico dessa função.

Problema 7.8.5 Diferentes tipos de espaçamento de plantio provocam diferentes efeitos na produtividade e nas características físicas das culturas. Considerando que a produtividade (y), em $\mathrm{kg} / \mathrm{ha}$, de um maracujazeiro em função do espaçamento (x), em metros, entre plantas, é dada pela função afim y $=-2,2 \mathrm{X}+16000$. Responda os itens a seguir.

(a) Qual é a produtividade de maracujazeiro cujo plantio foi realizado com espaçamento entre plantas de 2,5 metros?

(b) Qual é a produtividade de maracujazeiro cujo plantio foi realizado com espaçamento entre plantas de 4,5 metros?

(c) 0 ocorre com a produtividade do maracujazeiro conforme o espaçamento entre plantas aumenta? 


\section{Estatística Básica Aplicada na Análise de Dados Agropecuários}

Descrever dados agropecuários de uma distribuição é demonstrar cada um dos elementos com seu real valor. Por exemplo, descrever a produção de soja no Paraná, a produção de arroz no rio Grande do Sul, ou mesmo a evolução do plantio de milho na Argentina.

O setor do agronegócio é fundamental na economia brasileira, por isso é de suma importância saber tratar e analisar os dados referentes a essa atividade econômica.

\subsection{Medidas de Tendência Central}

São números que possibilitam analisar o que acontece, caracteristicamente, em diferentes agrupamentos de dados. São três as medidas centrais das distribuições estatísticas: média, mediana e moda. Cada uma delas explica uma parte do comportamento da amostra, mas esconde outra.

\subsubsection{Média Aritmética}

É a soma dos valores dividida pela frequência total dos dados. Em geral, representamos a média pela notação $\overline{\mathrm{X}}$.

Exemplo 8.1.1.1 A tabela a seguir mostra a produção, em toneladas, da safra de arroz no Rio Grande do Sul.

\begin{tabular}{c|c}
\hline Período & Produção (milhões de toneladas) \\
\hline $2011 / 12$ & 7,74 \\
\hline $2012 / 13$ & 7,93 \\
\hline $2013 / 14$ & 8.11 \\
\hline $2014 / 15$ & 8,62 \\
\hline $2015 / 16$ & 7,96 \\
\hline \multicolumn{2}{c}{ Fonte: Conab }
\end{tabular}

A média da produção de arroz no RS no período de 2011 a 2016 é:

$$
\bar{X}=\frac{7,74+7,93+8,11+8,62+7,96}{5}=8,07
$$

Portanto, a média da produção de arroz no RS nesse período foi de 8,07 milhões de toneladas.

Exemplo 8.1.1.2 Observe abaixo referente a produção da soja no MT, em milhões de toneladas. 


\section{Safra de Soja no MT \\ (em milhões de toneladas)}

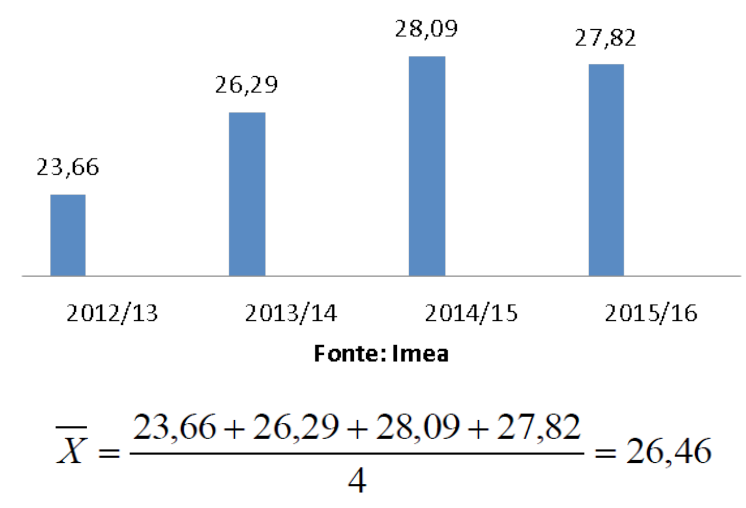

Logo, a produção média de soja em MT de 2012 a 2016 foi de 26,46 milhões de toneladas.

De modo geral, dados os valores $\mathrm{X}_{1}, \mathrm{X}_{2}, \mathrm{X}_{3}, \ldots, \mathrm{X}_{\mathrm{n}}$ a média aritmética $\overline{\mathrm{X}}$ desses dados é dada por:

$$
\begin{gathered}
\bar{X}=\frac{X_{1}, X_{2}, X_{3}, \cdots, X_{n}}{n} \\
\bar{X}=\frac{\sum_{i=1}^{n} X_{i}}{n}
\end{gathered}
$$

\subsubsection{Mediana}

É o valor central de uma distribuição de dados. Para identificar o valor mediano de uma distribuição de dados primeiro é necessário escrevê-los em ordem crescente. Para denotarmos o valor mediano usaremos a notação $\mathrm{M}_{\mathrm{d}}$.

Exemplo 8.1.2.1 O gráfico abaixo mostra o preço do boi gordo comercializado em Araçatuba-SP.

Preços do boi gordo em Araçatuba (em R\$/arroba)

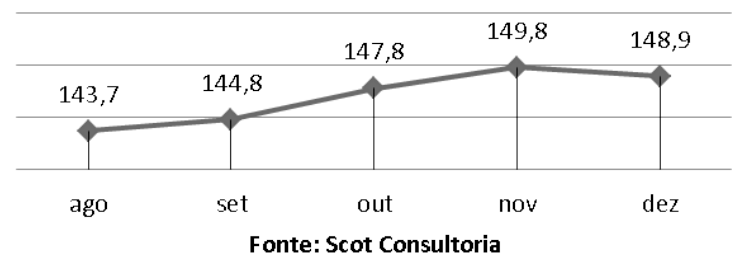


Escrevendo os valores em ordem crescente temos:

143,$7 ; 144,8 ; \mathbf{1 4 7 , 8} ; 148,9 ; 149,8$

Portanto, o preço mediano em reais da arroba do boi gordo segundo o gráfico é $\mathrm{R} \$$ 147,80 .

Exemplo 8.1.2.2 A tabela abaixo mostra o rebanho bovino argentino em milhões de cabeça.

\begin{tabular}{c|c}
\hline Ano & Milhões de cabeças \\
\hline 2012 & 49,9 \\
\hline 2013 & 51 \\
\hline 2014 & 51,6 \\
\hline 2015 & 51,4 \\
\hline
\end{tabular}

Fonte: Ministério da Agroindústria

$$
49,9 ; 51 ; 51,4 ; 51,6
$$

Nesse caso, como temos uma quantidade par de dados, o valor mediano é determinado pela média aritmética dos dois elementos centrais da distribuição de dados em ordem crescente.

$$
M_{o}=\frac{51+51,4}{2}=51,2
$$

Portanto, o valor mediano do número de cabeças do rebanho argentino foi de 51,2 milhões de cabeças.

\subsubsection{Moda}

Moda é o valor com maior frequência de uma distribuição de dados. Usaremos a notação para designar o valor modal de uma distribuição de dados.

Exemplo 8.1.3.1 A tabela abaixo mostra o preço do leite pago ao produtor em $\mathrm{R} \$$ o litro.

\begin{tabular}{c|c}
\hline Mês/Ano & R\$ (Litro) \\
\hline Set/2015 & 0,96 \\
\hline Out/2015 & 0,96 \\
\hline Nov/2015 & 0,95 \\
\hline Dez/2015 & 0,96 \\
\hline \multicolumn{2}{|c}{ Fonte: Scot Consultoria }
\end{tabular}

Sendo assim, a moda do preço do leite foi de $\mathrm{R} \$ 0,96$. 


\subsection{Medida de Dispersão: Desvio Padrão}

o desvio padrão é a medida mais corriqueira da dispersão estatística. Para representar essa medida utilizamos a notação $\sigma$. 0 desvio padrão mede o quanto a média em média se afasta dos dados da distribuição. Quanto mais próximo de zero for o valor do desvio padrão, os dados tendem a estarem mais próximos da média; Em outras palavras, a distribuição dos dados tende a ser mais homogênea. Por outro lado, quanto maior for o valor do desvio padrão, os dados tendem a estarem espalhados em torno da média.

Considere a distribuição de dados $\mathrm{X}_{1}, \mathrm{X}_{2}, \mathrm{X}_{3}, \ldots, \mathrm{X}_{\mathrm{n}}$. Então, o desvio padrão dessa distribuição é dado por:

$$
\begin{gathered}
\sigma=\sqrt{\frac{\left(\bar{X}-X_{1}\right)^{2}+\left(\bar{X}-X_{2}\right)^{2}+\cdots+\left(\bar{X}-X_{n}\right)^{2}}{n}} \\
\sigma=\sqrt{\sum_{i=1}^{n} \frac{\left(\bar{X}-X_{i}\right)^{2}}{n}}
\end{gathered}
$$

Exemplo 8.2.1.1 0 gráfico a seguir mostra a evolução do preço do milho (em R $\$$ por saca de 60kg) comercializado em Campinas - SP.

\section{Preço do milho em Campinas -SP \\ (em R\$/saca de $60 \mathrm{~kg}$ )}

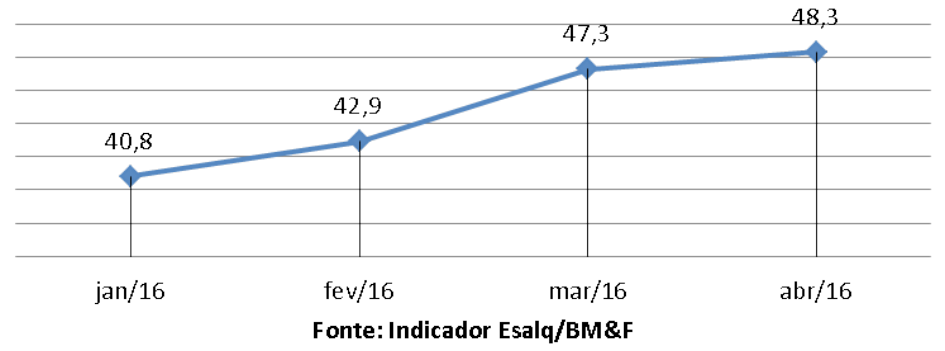

Preço médio é dado por:

$$
\bar{X}=\frac{40,8+42,9+47,3+48,3}{4}=44,82
$$

Dessa forma, o desvio padrão é:

$$
\begin{aligned}
\sigma & =\sqrt{\frac{(44,82-40,8)^{2}+(44,82-42,9)^{2}+(44,82-47,3)^{2}+(44,82-48,3)^{2}}{4}} \\
\sigma & =\sqrt{\frac{16,16+3,68+6,15+12,11}{4}} \\
\sigma & =\sqrt{\frac{38,1}{4}} \\
\sigma & =\sqrt{9,52} \\
\sigma & =3,08
\end{aligned}
$$


Isso significa que o preço da saca de milho nesse período oscilou $\mathrm{R} \$ 3,08$, em média, em torno do preço médio registrado nesse mesmo período.

\subsection{Problemas - Capítulo 8}

Problema 8.3.1 No ano de 2016 as cotações do milho dispararam impulsionadas pela exportação recorde. Os produtores negociaram $50 \%$ da safra antes mesmo da semeadura O gráfico a seguir mostra a evolução do preço do milho nos últimos 5 anos.

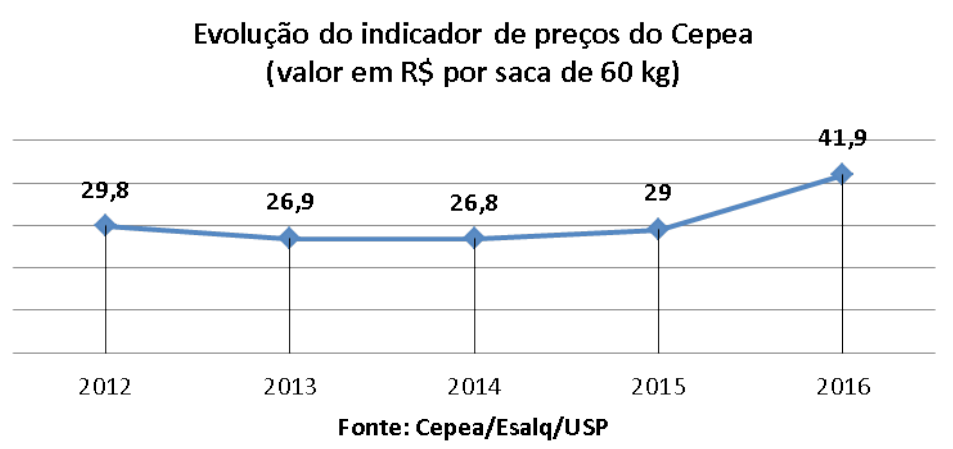

(a) Calcule o preço médio da saca de milho no período de 2012 até 2016.

(b) Calcule o preço mediano da saca de milho no período de 2012 até 2016.

(c) Calcule o desvio padrão referente ao preço da saca de milho no período de 2012 até 2016.

Problema 8.3.2 A tabela abaixo mostra o preço do leite pago ao produtor no ano de 2016, de janeiro a abril.

\begin{tabular}{|c|c|}
\hline Mês & R\$(Litro) \\
\hline Jan & 0,96 \\
\hline Fev & 0,98 \\
\hline Mar & 1,00 \\
\hline Abr & 1,00 \\
\hline
\end{tabular}

Fonte: Scot Consultoria

(a) Calcule o preço médio do litro do leite.

(b) Calcule o preço mediano do litro do leite.

(c) Calcule o desvio padrão referente ao preço do litro do leite.

Problema 8.3.3 O volume das vendas do etanol foi recorde no mês de outubro de 2015, alcançando, pela primeira vez na série histórica, 50\% do consumo mensal de gaso- 
lina. 0 gráfico a seguir mostra a evolução do preço do litro do etanol referente aos anos de 2010 até 2015.

\section{Etanol Hidratado (R\$/Litro)}

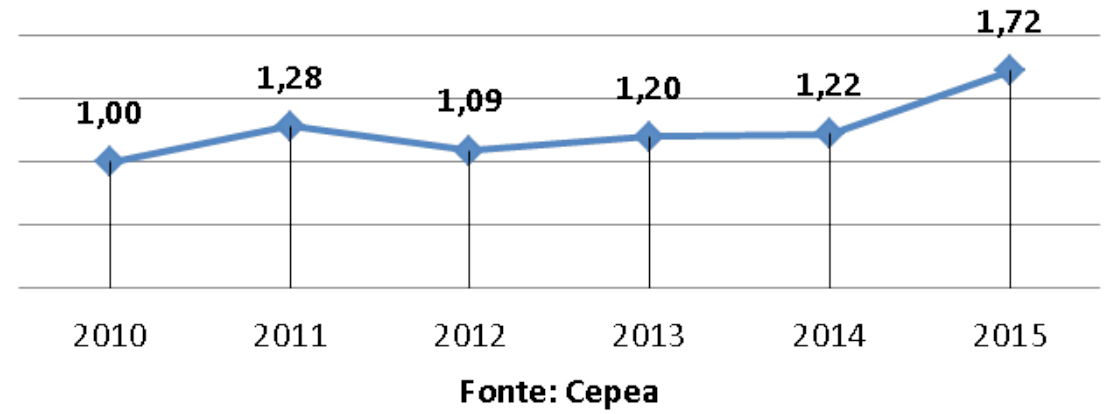

(a) Calcule o preço médio do etanol hidratado comercializado nesse período.

(b) Calcule o preço mediano do etanol hidratado comercializado nesse período.

(c) Calcule o desvio padrão referente ao preço do etanol hidratado nesse período.

Problema 8.3.4 O gráfico abaixo mostra a evolução da área plantada de soja em milhões de hectares.

\section{Área Plantada (milhões de hectares)}

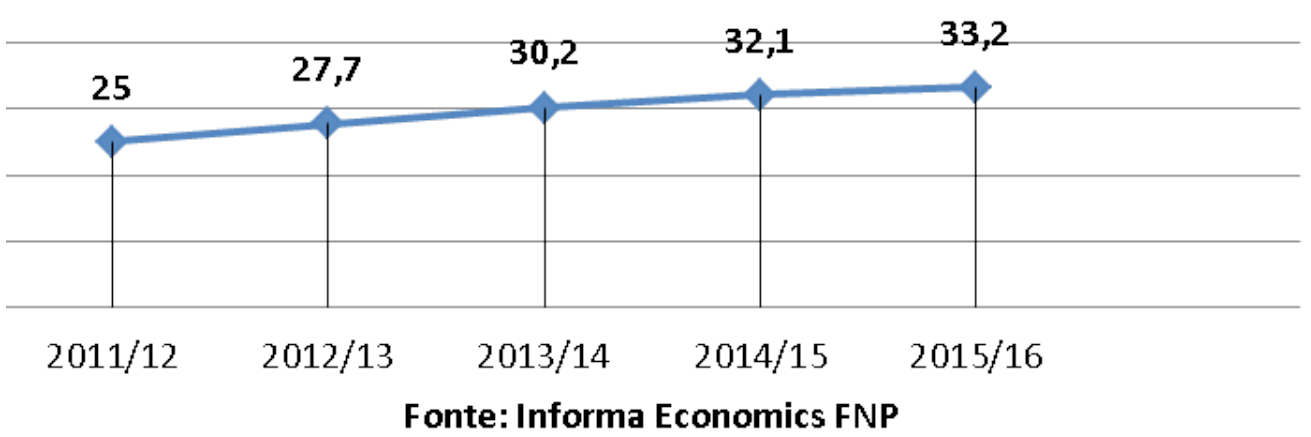

Calcule a área média plantada com soja.

Problema 8.3.5 Na esteira da crise, o setor de máquinas agrícolas atribui a diminuição nas vendas às agitações políticas que viciaram a economia brasileira ao longo do ano de 2015. 0 gráfico a seguir mostra a evolução das vendas internas de máquinas agrícolas. 


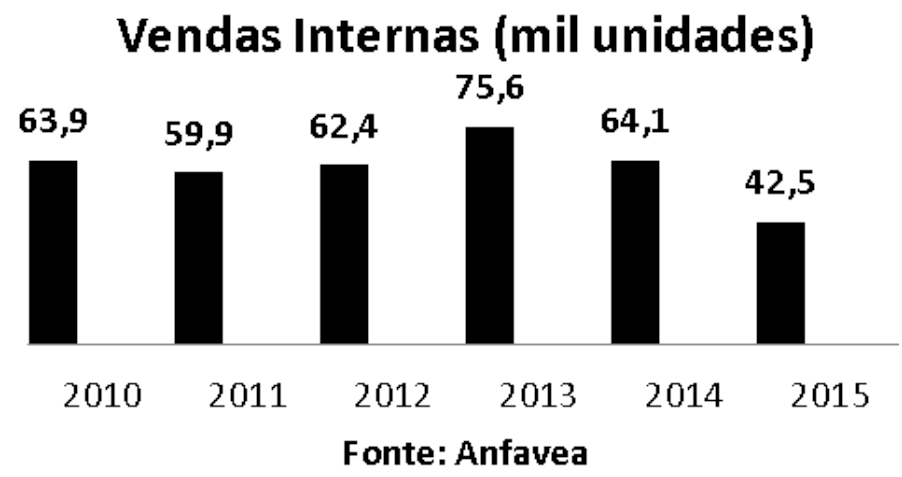

(a) Calcule o número médio de vendas internas de máquinas agrícolas no Brasil no período de 2010 até 2015.

(b) Determine o valor mediano do número de vendas de máquinas agrícolas no Brasil no período de 2010 até 2015.

(c) Calcule o desvio padrão referente ao número de vendas internas de máquinas agrícolas no Brasil no período de 2010 até 2015.

(d) Calcule a redução percentual das vendas internas de máquinas agrícolas no Brasil no ano de 2015 em relação ao ano de 2013. 


\section{Referências Bibliográficas}

DANTE, L. R. Projeto Teláris: matemática. 1. ed. São Paulo: Ática, 2012.

HOLTZ, M. A. et al. Produção agrícola sustentável. Itapina: Instituto Federal de Educação e Ciências, 2010.

LIMA, E. L. et al. A matemática do ensino médio - vol 2. Rio de Janeiro: Sociedade Brasileira de Matemática, 2006.

LIMA, E. L. et al. Temas e problemas. 3. ed. Rio de Janeiro: Sociedade Brasileira de Matemática, 2001.

Matemática: manual de orientações/MEC, SESG, SETC - Rio de Janeiro: FAE, 1989. 35 p. Série Ensino Agrotécnico: volume 5.

Matemática: manual de orientações/MEC, SESG, SETC - Rio de Janeiro: FAE, 1987. 58 p. Série Ensino Agrotécnico: volume 11.

Matemática: manual de orientações/MEC, SESG, SETC - Rio de Janeiro: FAE, 1988. 104 p. Série Ensino Agrotécnico: volume 14.

Matemática: manual de orientações/MEC, SESG, SETC - Rio de Janeiro: FAE, 1989. 35 p. Série Ensino Agrotécnico: volume 15.

MORGADO, A. C. et al. Progressões e matemática financeira. Rio de Janeiro: Sociedade Brasileira de Matemática, 2005.

PEREIRA, C. B. L.; JUNIOR, S. G. O ensino de matemática nas ciências agrárias: possíveis aproximações interdisciplinares, 2015.

PREZOTTI, L. C. Sistema de recomendação de calagem e adubação. Disponível em: http:www. incaper.es.gov. Acesso em: 06 abr. 2016.

Revista Brasileira de Fruticultura, v. 36, n. 1, mar. 2014.

Revista Brasileira de Fruticultura, v. 36, n. 2, jun. 2014.

Revista Brasileira de Fruticultura, v. 36, n. 3, set. 2014.

Revista GloboRural, v. 363, jan. 2016.

Revista GloboRural, v. 365, mar. 2016.

Revista GloboRural, v. 367, maio. 2016.

Revista GloboRural, v. 368, jun. 2016.

Revista PROCAMPO, n. 31 abr./maio 2011.

Revista PROCAMPO, n. 58, out./nov. 2015.

SAKOMURA, N. K.; ROSTAGNO, H. S. Métodos de pesquisa em nutrição de monogástricos. Jaboticabal: FUNEP, 2007. 283 p.

SPIEGEL, M. R. Estatística: resumo da teoria. São Paulo: McGraw-Hill do Brasil, 1975.

SOUZA, J. L. M. Manual de construções rurais. 3. ed. UFPR, 1997 
